\title{
SCYTHIAN AGE SETTLEMENT NEAR NAGYTARCSA
}

\author{
SZABOLCS CZIFRA ${ }^{1}$-ATTILA KREITER ${ }^{2}$-ÉVA KOVÁCS-SZÉLES ${ }^{3}$-MÁRIA TÓTH ${ }^{4}$ - \\ ORSOLYA VIKTORIK ${ }^{2}$ - BEÁTA TUGYA ${ }^{5}$ \\ ${ }^{1}$ Hungarian National Museum, Department of Archaeological Excavations and Artefact Processing \\ Daróci út 3, H-1113 Budapest, Hungary \\ czifra_sz@yahoo.com; czifra.szabolcs@hnm.hu \\ ${ }^{2}$ Hungarian National Museum, Laboratory for Applied Research, Daróci út 3, H-1113 Budapest, Hungary \\ attila.kreiter@gmail.com; orsolya.viktorik@gmail.com \\ ${ }^{3}$ Hungarian Academy of Sciences Centre for Energy Research, Konkoly Thege Miklós utca 29-33, H-1121 Budapest, Hungary \\ szeles.eva@energia.mta.hu \\ ${ }^{4}$ Hungarian Academy of Sciences Institute for Geological and Geochemical Research \\ Budaörsi út 45, H-1112 Budapest, Hungary \\ totyi@geochem.hu \\ ${ }^{5}$ György Thúry Museum, Zrínyi Miklós utca 62, H-8800 Nagykanizsa, Hungary \\ tbea82@gmail.com
}

\begin{abstract}
This paper deals with the archaeological material of a Scythian Age settlement excavated near Nagytarcsa in 2007. Located on the higher terrace of a stream, the site represents a characteristic lowland, hamlet-like settlement of the Vekerzug culture, where animal husbandry played an important role in subsistence. Based on diagnostic ceramic finds and radiocarbon dating the settlement can be assigned to the Ha D2 period. The archaeological description, as well as the evaluation of settlement features and finds, is supplemented with a detailed petrographic analysis with an emphasis on wheel-thrown and Hallstatt type ceramics. The petrographic and geochemical analysis of the sherds and sediments collected on the site aim to confirm archaeological interpretations in order to determine the provenance of the ceramics and to assess whether their technological characteristics suggest specialization in production.
\end{abstract}

Keywords: Early Iron Age, Vekerzug Culture, settlement, pottery, technology, specialization, archaeozoology

\section{ARCHAEOLOGICAL INTERPRETATION OF THE SCYTHIAN AGE SETTLEMENT \\ (SZABOLCS CZIFRA)}

\subsection{Introduction}

Prior to the construction of the northern M31 Motorway, a preventive archaeological excavation was conducted near the settlement of Nagytarcsa, in Urasági-dűlő (North-Central Hungary). Excavations took place between the $21^{\text {st }}$ of June and the $24^{\text {th }}$ of September in 2007. The multi-period site is located northeast of Nagytarcsa, on the gentle southern slopes of Körmös Mountain, north of Szilas Creek. ${ }^{1}$

Locals were already collecting ceramics in this area in the 1960s. Archaeological field surveys of the site were conducted in the 1980s. ${ }^{2}$ The area of the archaeological site on the slope affected by gully erosion was determined to be $1500 \mathrm{~m}$ x 200-250 m. The dominance of Roman Imperial Age (Sarmatian) finds was recorded. Only an archaeological survey was conducted in this area prior to the motorway construction works; first in $2007^{3}$ and later as a follow-up survey in 2009. ${ }^{4}$ The Early Iron Age settlement presented in this study comprised 19 features. It was found in the southern part of the site, near the banks of the creek, during the 2007 excavation (Fig. 1).

\footnotetext{
${ }^{1}$ Nagytarcsa lies on the alluvial fan of the Danube (Pesti hordalékkúp-síkság), which is characterized by interfluves, higher terraces, and both erosion and derasion valleys. Typical geomorphological forms found on its territory developed due to fluvial and derasion processes (MAROSI-SOMOGYI 1990), in which the Danube played an es-
}

sential role (BoRsy 1989). The landscape around Nagytarcsa is formed today by the Csincsa and Szilas Creeks that feed into the Danube.

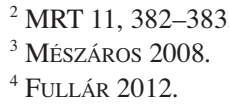



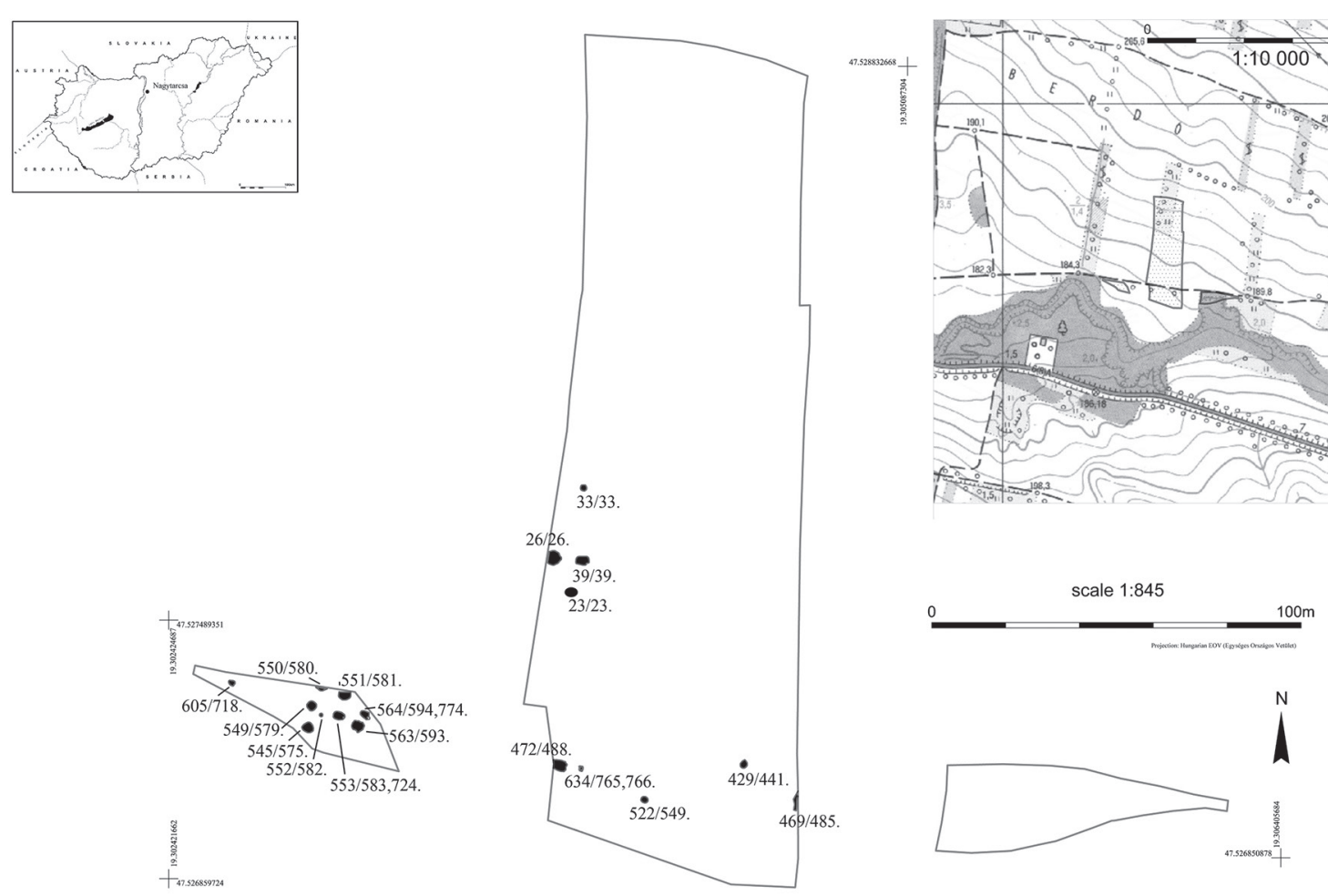

Fig. 1. Nagytarcsa-Urasági-dủlő: Location of the excavated Early Iron Age features

\subsection{The excavated Scythian period features}

Amongst the archaeological phenomena revealed at Nagytarcsa-Urasági-dülö, the features described below can be securely associated with the Scythian period. ${ }^{5}$

Feature 23/23. (Fig. 2, Fig. 5): Oval pit with a curved, tapering sidewall and slightly uneven bottom. The pit was found near the western wall of the excavation trench and it was bisected by a Roman Imperial Age (Sarmatian) ditch 93/93. Measurements: 1: app. $400 \mathrm{~cm}$; w: $282 \mathrm{~cm}$; de: $55-80 \mathrm{~cm}$.

Finds: A total of 11 ceramic fragments came to light in the dark brown fill of the pit. Three were fragments from a hand-formed, barrel-shaped pot. One was from a wheel-turned cup, and another from a Hallstatt type mug. The six additional hand-formed fragments belonged to undiagnostic vessel types (Inv.No: 1.26213.23.1-13; Fig. 10.1-5).

Feature 26/26. (Fig. 2, Fig. 5): Large, irregular, oval pit with vertically tapering sidewalls. Its bottom was slightly curved. Unfortunately a part of it was situated outside the western trench wall. On the level of the scraped surface, the fill of the pit was composed of dark brown sand with a high humus content. Below this, a burnt layer with large daub fragments was recorded. A grey, ashy sand layer was observed at the bottom of the pit. Measurements: 1: $400 \mathrm{~cm}$; $: 230 \mathrm{~cm}$; de: $110 \mathrm{~cm}$. This pit contained the majority of the ceramic finds.

Finds: Fragments of 13 barrel-shaped and two biconical pots, seven bowls with inverted rims, six cups and one Hallstatt type mug were recovered from the fill. Wheel-thrown vessel types were represented by only two

\footnotetext{
${ }^{5}$ The codes for the features are comprised of the number of the given feature (first digit) and the stratigraphic unit (SU) (second digit) they come from. Abbreviations used in the following descrip-
}

tions are: $d=$ diameter, $1=$ length, $w=$ width, $d e=$ depth, Inv. No. $=$ Inventory Number. 

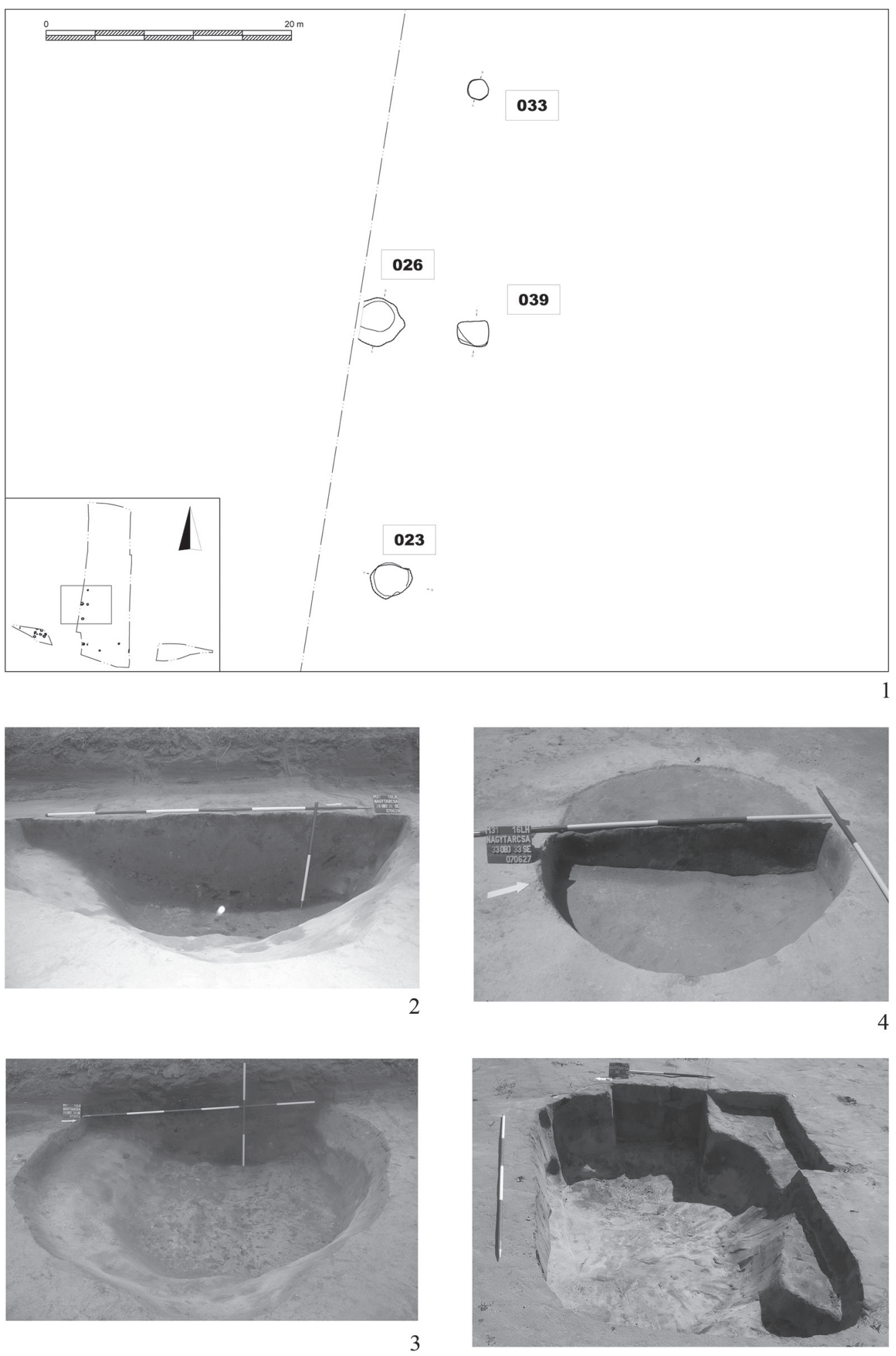

Fig. 2. Nagytarcsa-Urasági-dủlő. Northern part of the Scythian Age settlement 

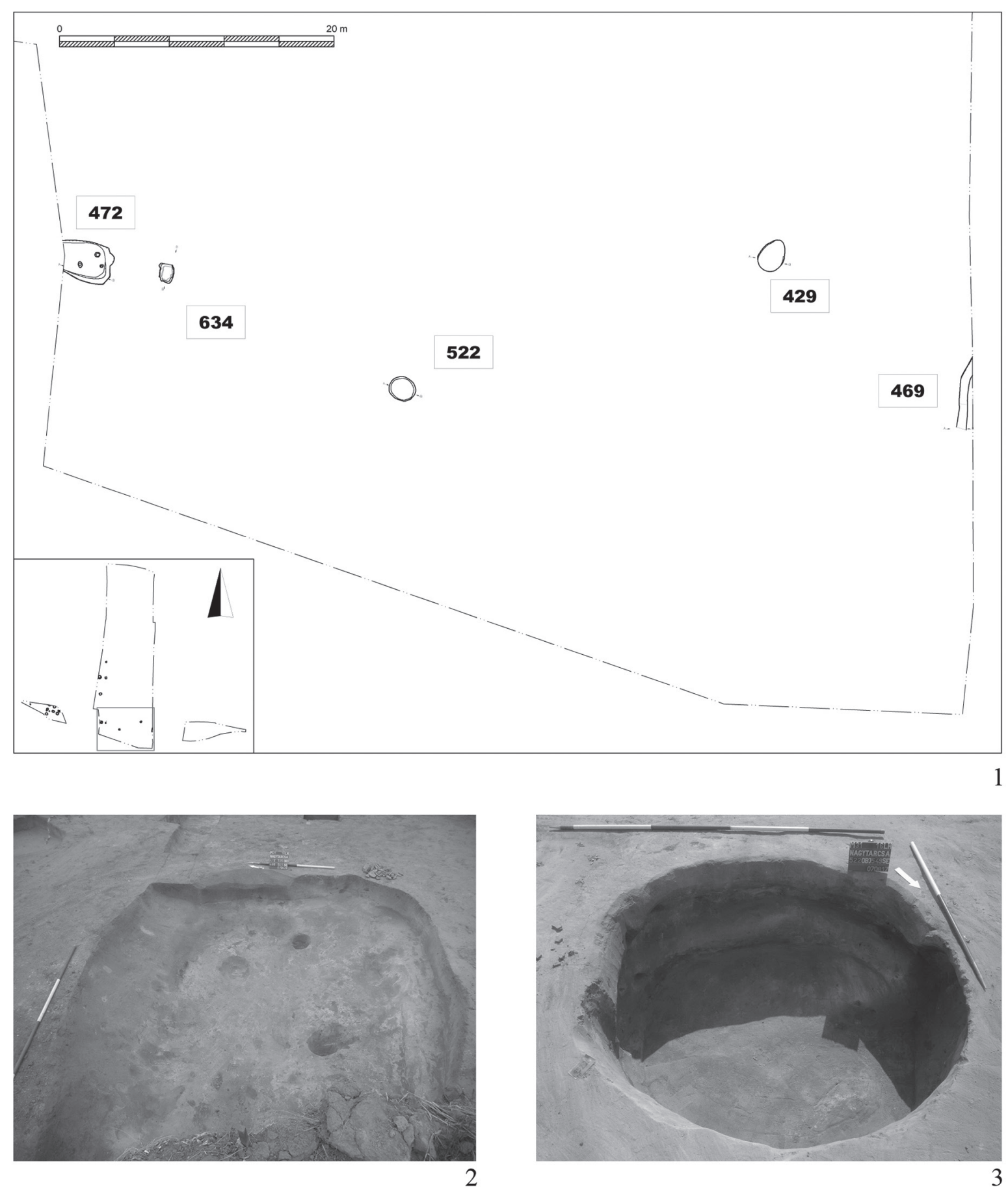

Fig. 3. Nagytarcsa-Urasági-dűlő. Southern part of the Scythian Age settlement 

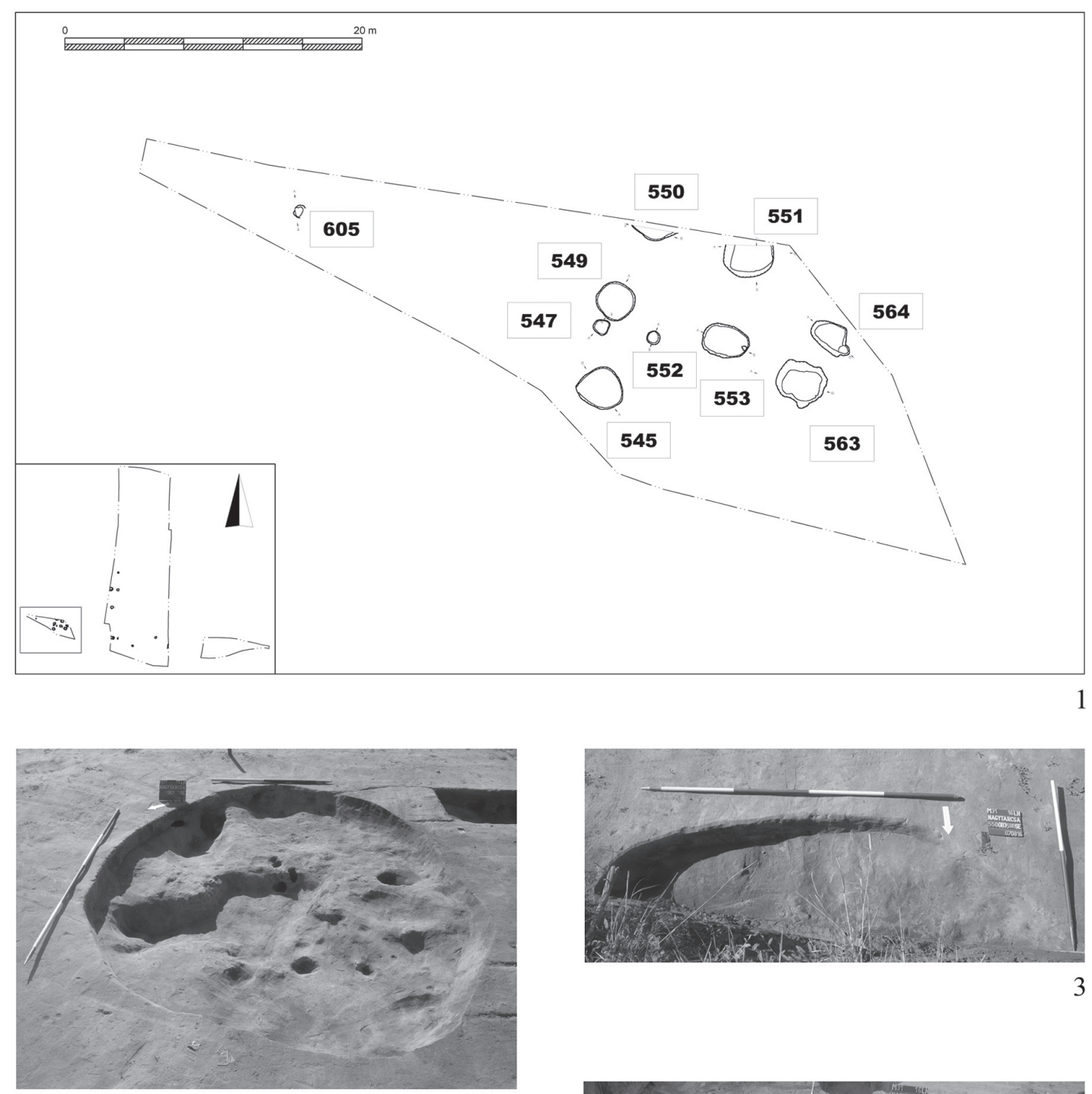

2
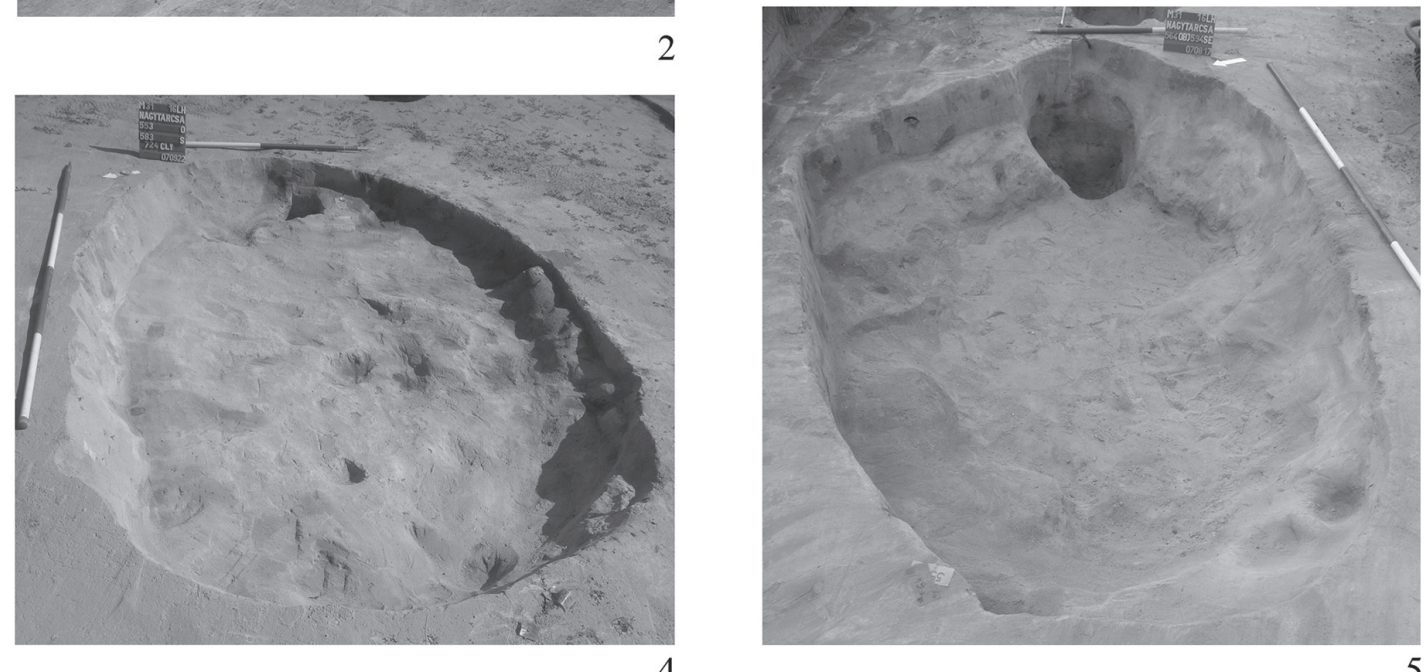

Fig. 4. Nagytarcsa-Urasági-dűlő. Western part of the Scythian Age settlement 


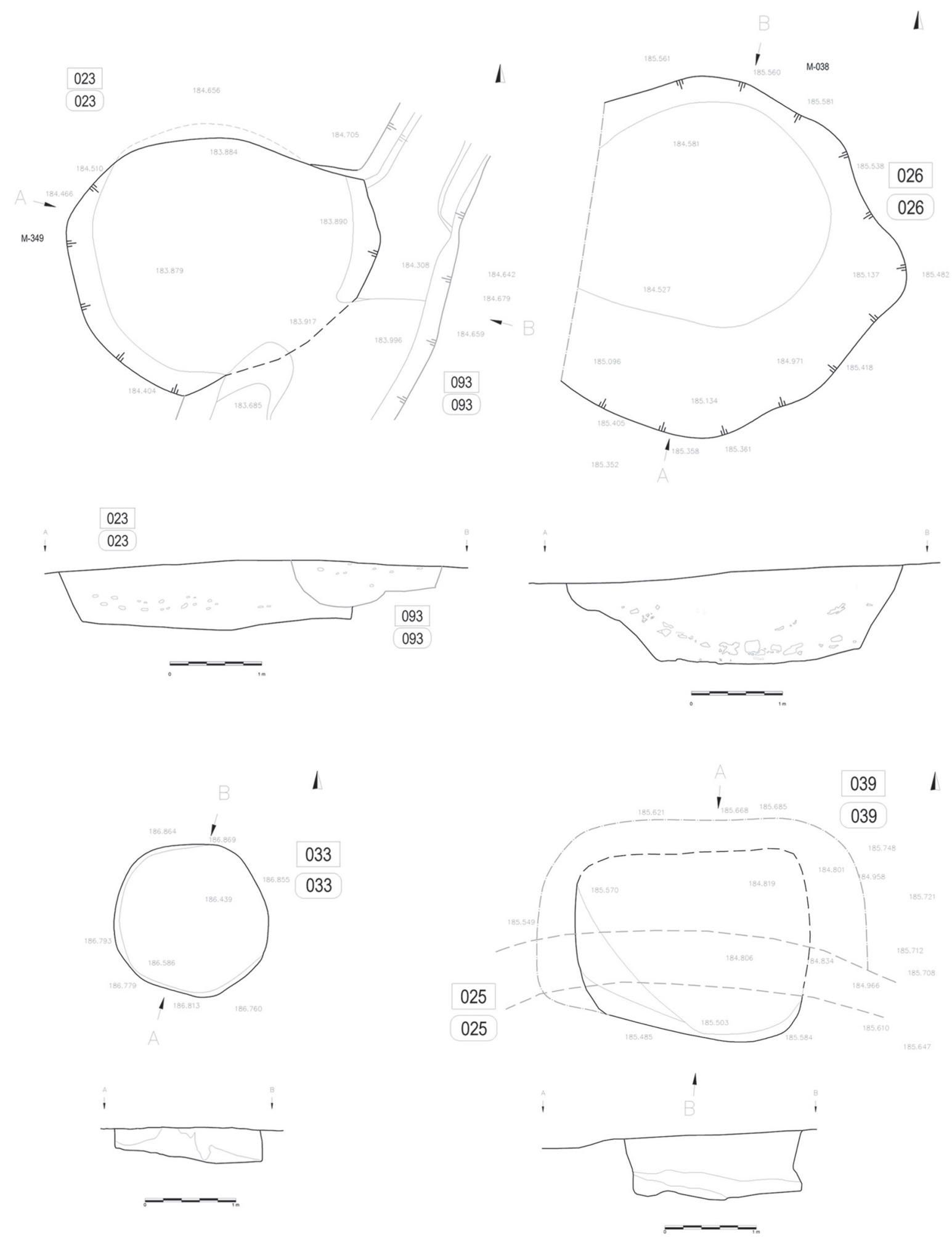

Fig. 5. Nagytarcsa-Urasági-dülö. Ground-plan and cross-section of the Scythian Age features 

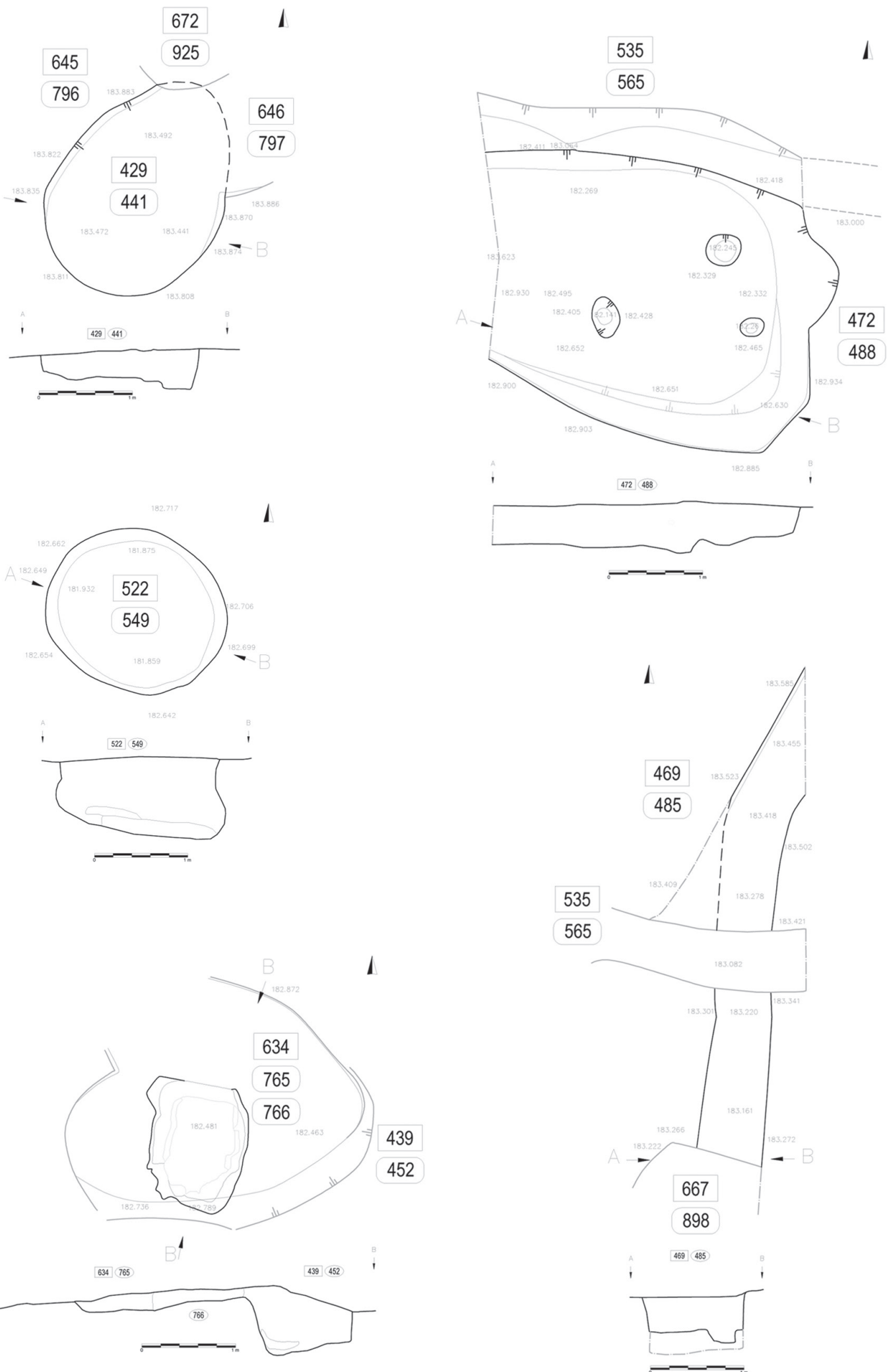

Fig. 6. Nagytarcsa-Urasági-dülő. Ground-plan and cross-section of the Scythian Age features 

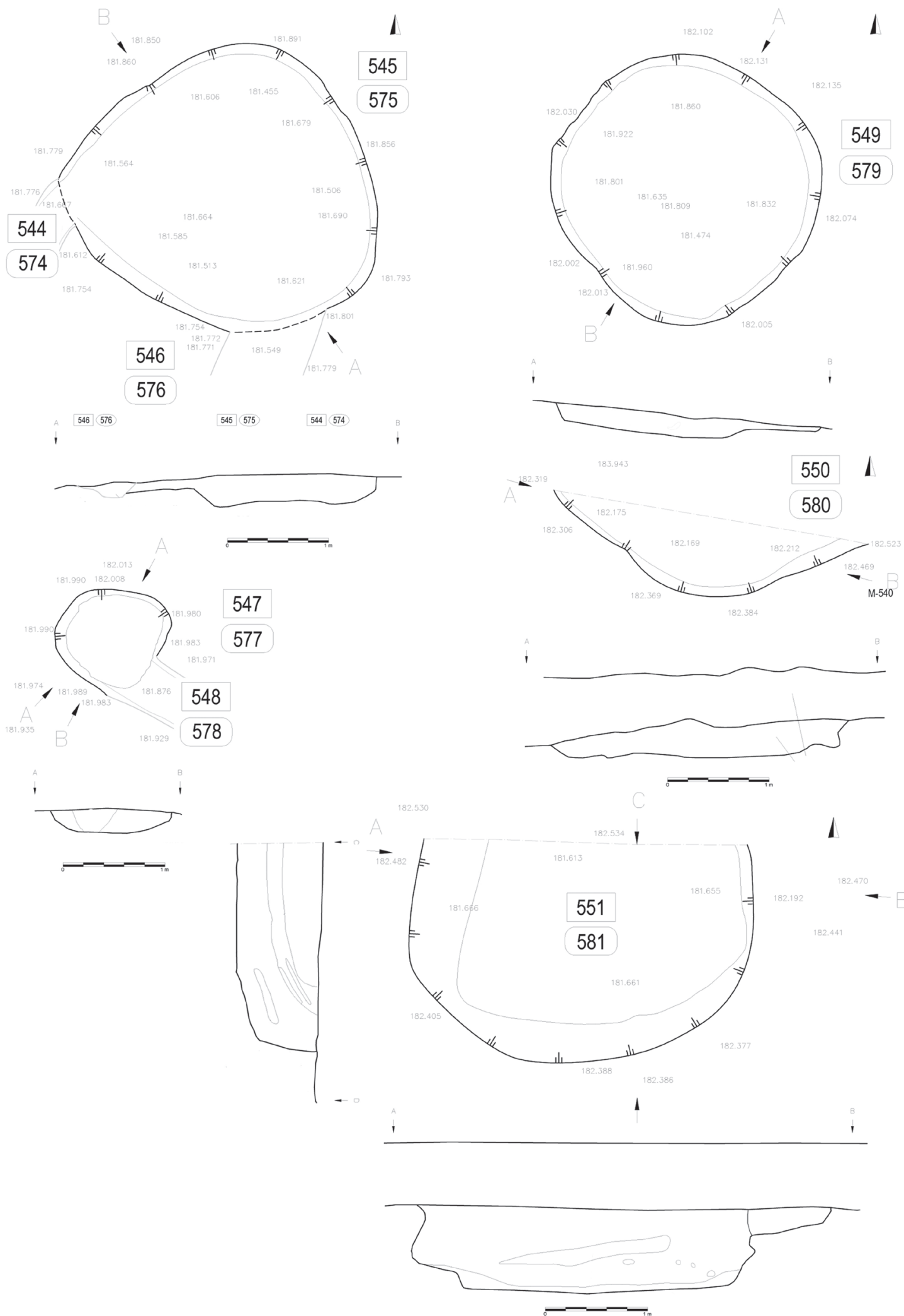

Fig. 7. Nagytarcsa-Urasági-dülő. Ground-plan and cross-section of the Scythian Age features Acta Archaeologica Academiae Scientiarum Hungaricae 68, 2017 


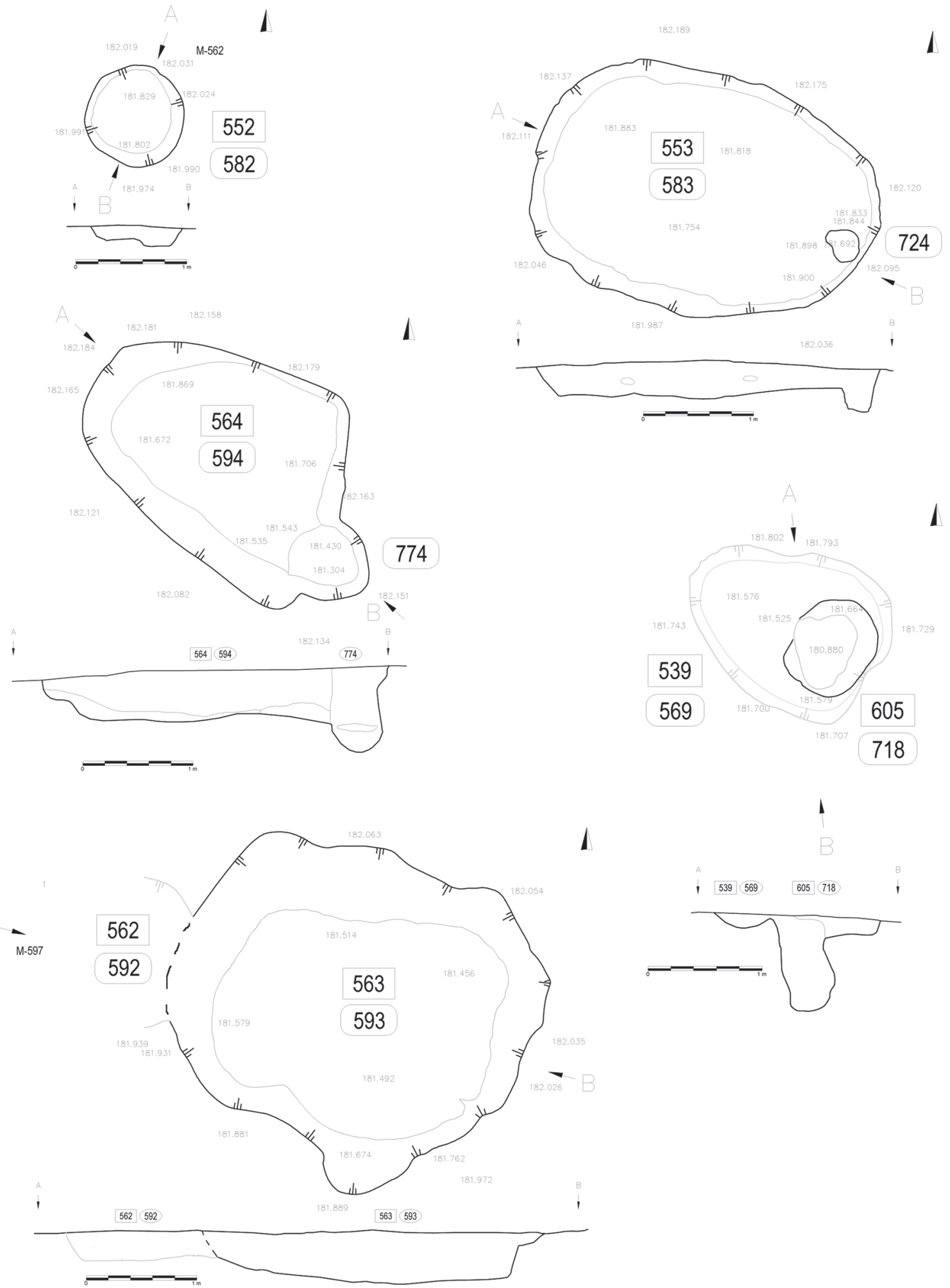

Fig. 8. Nagytarcsa-Urasági-dűlő. Ground-plan and cross-section of the Scythian Age features 
sherds from biconical cups and three sherds from jugs. In addition to the above-mentioned finds, 21 hand-formed sherds were found in the pit. Their type could not be identified (Inv. Nos: 1.26213.26.1-78; Fig. 9.1-22).

Feature 33/33. (Fig. 2, Fig. 5): A circular shallow pit with straight vertical sidewalls and a slightly uneven bottom. The fill of the pit contained dark brown sandy humus and greyish sand layers. Measurements: $\mathrm{d}: 170 \times 165 \mathrm{~cm}$; de: $20-38 \mathrm{~cm}$

Finds: One rim fragment from a hand-formed bowl, and one body fragment from a hand-formed vessel were recovered from the fill of the pit (Inv. Nos: 1.26213.33.1-2; Fig. 10.6).

Feature 39/39. (Fig. 2, Fig. 5): Oval, slightly beehive-shaped, deep pit. The upper layers of the pit fill contained dark brown sand with a high humus content. A black sand layer with burnt daub fragments was recorded in the lower levels, while the deepest layer comprised greyish brown sand. Measurements: d: $280 \times 105 \mathrm{~cm}$; de: $78 \mathrm{~cm}$. Part of the pit was disturbed by a Roman Imperial Period (Sarmatian) ditch 25/25.

Finds: Fragments of two barrel-shaped pots, one wheel-thrown jug, and two atypical body fragments came to light from this pit (Inv. Nos: 1.26213.39.1-6; Fig. 10.7-8).

Feature 429/441. (Fig. 3, Fig. 6): The pit appeared as a slightly oval patch on the scraped surface. Its sidewalls tapered slightly and its bottom was somewhat uneven. Its fill was an almost homogenous dark brown sand with a high humus content. Measurements: d: $220 \times 180 \mathrm{~cm}$; de: $38 \mathrm{~cm}$. The northern part of the feature was disturbed by two features, which subsequently dug into it (Pits 645/796. and 672/925.).

Finds: A large number of ceramic fragments were found in the pit, the majority of which (7 pcs) came from a barrel-shaped pot. It was not possible to determine whether five additional, atypical body fragments also belonged to a pot or a hand-formed bowl. Fragments of two hand-formed bowls with inverted rims, two cups, one piece from a large biconical bowl, as well as a non-Iron Age ceramic sherd were also found in the pit. In addition, one body fragment from a wheel-thrown jug-like vessel was also recovered there (Inv. Nos: 1.26213.441.1-27; Fig. 11.1-10).

Feature 469/485. (Fig. 3, Fig. 6): A more or less, north-south oriented, slightly curving, short, narrow, shallow ditch. Only a short section of the ditch could be excavated.

Finds: The feature only contained one fragment of a barrel-shaped pot and one undiagnostic ceramic sherd fragment (Inv. Nos: 1.26213.485.1-2).

Feature 472/488. (Fig. 3, Fig. 6): Square pit of a semi-subterranean structure with markedly rounded edges. It presented as an elongated, slightly oval patch during the removal of the humus. It had a dark brown sand fill with a high humus content. A narrow berm ran along the southern side of the feature. By its eastern side, it gradually ended in the floor of the semi-subterranean construction. Four post holes were identified in the ground plan of the feature; they were not assigned to stratigraphic unit-numbers. Measurements: $1 . \mathrm{d}: 36 \times 42 \mathrm{~cm}$; de: $9 \mathrm{~cm} .2$. d: $20 \times 24 \mathrm{~cm}$; de: $17 \mathrm{~cm}$. 3. d: $33 \times 40 \mathrm{~cm}$; de: $25 \mathrm{~cm}$. 4 . d: $35 \mathrm{~cm}$; de: $10 \mathrm{~cm}$; w. of the semi-subterranean construction: $350 \mathrm{~cm}$; de. of the floor: $65 \mathrm{~cm}$; de. of the berm: 28-30 cm. The Scythian Period semi-subterranean construction was disturbed by ditch 535/555, which could not be dated.

Finds: The fill of the semi-subterranean house contained fragments of six hand-formed pots, sherds of one large, biconical vessel, two cups, two bowls with inverted rims, one lid, and a fragment of a handle. This handle fragment may also have belonged to a hand-formed or wheel-thrown vessel. Only four wheel-thrown vessels (two cups and two bowls) were unearthed. For nine fragments it was not possible to determine the original vessel type (Inv. Nos: 1.26213.488.1-33; Fig. 12.1-18).

Feature 522/549. (Fig 3, Fig. 6): Large, oval pit with slightly bulging sidewalls and an uneven bottom. In addition to a thin humus layer near the bottom, the fill of the pit largely contained reddish-brown sand. Measurements: d: $183 \times 170 \mathrm{~cm}$; de: $70-85 \mathrm{~cm}$.

Finds: Five uncharacteristic Iron Age body fragments were found in the pit (Inv. Nos: 1.26213.549.1-6). 
Feature 545/575. (Fig. 4, Fig. 7): Large, roundish pit with sloping benches on its sidewalls and an uneven bottom. Its fill contained brownish sand with a high humus content, burnt daub fragments, and pieces of charcoal. Measurements: d: $300 \mathrm{~cm}$; de: $23-33 \mathrm{~cm}$. Seven ditches dating to subsequent archaeological eras disturbed the feature.

Finds: One Hallstatt style vessel fragment decorated with knobs that were pressed out from the interior of the vessel, two fragments of a hand-formed, barrel-shaped pot, and one fragment of a biconical vessel were found in the pit. The feature also contained ten atypical Iron Age ceramic fragments. (Inv. Nos: 1.26213.575.1-15; Fig. 13.1-6).

Feature 547/577. (Fig. 4, Fig. 7): Small, shallow, oval pit with cylindrical sidewalls. Its fill comprised yellowishbrown sand. Measurements: 1: $125 \mathrm{~cm}$; w: $90 \mathrm{~cm}$; de: $20 \mathrm{~cm}$. Ditch 548/578 disturbed the eastern part of the pit.

Finds: Only two atypical Iron Age, and four Neolithic (Zseliz culture) vessel fragments were found in the pit (Inv. Nos: 1.26213.577.1-8; Fig. 13.7-10).

Feature 549/579. (Fig. 4, Fig. 7): Large, slightly oval, shallow pit with uneven bottom. The fill of the pit was dark brown sand with burnt daub fragments. Measurements: 1: $260 \mathrm{~cm}$; w: $240 \mathrm{~cm}$; de: 5-20 cm.

Finds: Fragments of two hand-formed, barrel-shaped pots, one biconical vessel, one bowl with inverted rim, one biconical cup, and five atypical Iron Age body fragments were recovered from the pit (Inv. Nos: 1.26213.579.1-13; Fig. 13.11-16).

Feature 550/580. (Fig. 4, Fig. 7): Large, oval, shallow pit with sloping benches on its sidewalls and a concave bottom. Its fill was dark brown humus material interspersed with daub flecks. Measurements: 1: $300 \mathrm{~cm}$; w: $75 \mathrm{~cm}$; de: $35 \mathrm{~cm}$.

Finds: Three pieces of atypical, hand-formed Iron Age ceramic fragments and some animal bones were recovered (Inv. Nos: 1.26213.580.1-5).

Feature 551/581. (Fig. 4, Fig. 7): Large and deep oval pit with sloping benches on its sidewalls. Its fill was predominantly dark brown sand with a high humus content. Burnt daub fragments and charcoal flecks were visible in the fill. The bottom of the pit was a hard, light grey layer which was interspersed with yellow patches. Measurements: 1: $320 \mathrm{~cm}$; w: $210 \mathrm{~cm}$; de: $90 \mathrm{~cm}$. The northern part of the pit lay outside the excavation trench; therefore the pit could not be excavated.

Finds: Fragments of eleven hand-formed pots, of three biconical pots, of one bowl with inverted rim and of one wheel-turned jug could be identified. In addition to the above-mentioned finds, 13 hand-formed vessel fragments, and one wheel-turned fragment of an undiagnostic vessel type were recovered (Inv. Nos: 1.26213.581.1-33; Fig. 14.1-21).

Feature 552/582. (Fig. 4, Fig. 8): Small, rounded, shallow pit with cylindrical sidewalls. Measurements: d: $85 \mathrm{~cm}$; de: $15 \mathrm{~cm}$.

Finds: The fill of the pit contained only one fragment of an undiagnostic vessel type (Inv. Nos: 1.26213.582.1).

Feature 553/583. (Fig. 4, Fig. 8): Large, oval, shallow pit with sloping benches on its sidewall. Its fill was predominantly dark brown, sandy humus with burnt daub fragments. One posthole (724. SU) could be identified in the eastern part of the pit. Measurements: 1: $310 \mathrm{~cm}$; w: $215 \mathrm{~cm}$; de: $35 \mathrm{~cm}$. The posthole d: $30 \times 25 \mathrm{~cm}$; de: $40 \mathrm{~cm}$.

Finds: Fragments of one hand-formed and one wheel-turned cup, two hand-formed biconical pots, and one bowl with an inverted rim could be identified from the fill of the pit. An additional 13 hand-formed fragments could not be associated with certain vessel types. In addition to the above-mentioned finds, one handle fragment of a mug decorated with horn-like projections, and one Hallstatt type mug with grooved decoration on its shoulder were recovered from the pit (Inv. Nos: 1.26213.583.1-25; Fig. 15.1-12). 
Feature 563/593. (Fig. 4, Fig. 8): Large, irregular oval, moderately deep pit with steps on its sidewall. It appeared as a large brown sandy patch on the scraped surface. Measurements: 1: $320 \mathrm{~cm}$; w: $260 \mathrm{~cm}$; de: $60 \mathrm{~cm}$.

Finds: Fragments of two hand-formed, barrel-shaped pots, of two biconical pots, as well as eight atypical body fragments were recovered from the pit. Amongst the typologically undiagnostic body fragments only one was wheel-turned. (Inv. Nos: 1.26213.53.1-12; Fig. 15.13-16).

Feature 564/594. (Fig. 4, Fig. 8): Large, oval pit with uneven bottom. Berms were found on its shorter sides. The fill of the pit was predominantly brownish humus with burnt daub and lime fragments. Thin, yellowish-brown and yellow sand layers appeared under this fill. Another small, rounded, moderately deep pit or posthole (SU 774) was found in the eastern part of the pit. It contained a characteristic, blackish-brown sand fill with burnt daub fragments. At the lower part of the fill a 3-4 cm thick charcoal layer could be distinguished. Measurements: 1: $320 \mathrm{~cm}$; w: $200 \mathrm{~cm}$; de: $35-55 \mathrm{~cm}$. 774. SU d: $85 \mathrm{~cm}$; de: $35-55 \mathrm{~cm}$.

Finds: Fragments of one hand-formed biconical pot, of one wheel-turned jug, as well as ten undiagnostic, hand-formed vessel fragments were recovered from Pit 564/594. (Inv. Nos: 1.26213.594.1-13; Fig. 16.1-2). Pit 564/774. contained slightly more identifiable ceramic fragments (Inv. Nos: 1.26213.774.1-10; Fig. 16.3-12). In the find assemblage of this feature fragments from four hand-formed, barrel-shaped pots, one biconical cup, one wheelturned jug and bowl, one handle fragment, one uncharacteristic body fragment, and rim and body fragments from one Hallstatt type mug were recovered.

Feature 605/718. (Fig. 4, Fig. 8): Middle-sized, oval pit. The sidewalls widen slightly while the bottom of the pit is curved. The feature was disturbed by Roman Imperial Period (Sarmatian) Pit 539/569. Measurements: d: $60 \times 50 \mathrm{~cm}$; de: $85 \mathrm{~cm}$.

Finds: Fragments from one hand-formed barrel-shaped pot, one wheel-turned bowl with inverted rim, as well as six atypical Iron Age ceramic fragments were brought to light in the wet, black, silty fill (Inv. Nos: 1.26213.718.1-9; Fig. 15.17-20).

Feature 634/765. (Fig. 3, Fig. 6): Oval, strongly eroded oven (?). Its sidewalls and vaulting had collapsed. A strongly burnt baking surface (766. SU) was plastered with clay and remained intact. Measurements: d: $150 \times 90 \mathrm{~cm}$. The feature was disturbed by a Roman Imperial Period (Sarmatian) Pit 439/452.

Finds: Fragments from one barrel-shaped pot, one hand-formed bowl, the neck fragment from a presumably Hallstatt type vessel, and two atypical ceramic sherds were recovered from the rubble of the oven (Inv.Nos: 1.26213.765.1-7; Fig. 16.13-15). One wheel-turned jug and one biconical pot, one handle fragment, as well as three undiagnostic vessel fragments were embedded in the baking surface (Inv. Nos: 1.26213.766.1-6; Fig. 16.16-17).

Several Early Iron Age vessel fragments were brought to light during the removal of the modern humus material, and from the fill of features from later archaeological periods. Only a small portion of these were wheelturned (Inv. Nos: 1.26213.0.4, 20, 39, 44; 1.26213.19.8; 1.26213.22.2; 1.26213.31.6; 1.26213.42.5; 1.26213.444.2; $1.26213 .451 .2-3 ; 1.26213 .452 .1-2 ; 1.26213 .478 .4-5 ; 1.26213 .495 .2-3 ; 1.26213 .528 .7-28 ; 1.26213 .569 .1 ;$ 1.26213.674.4; 1.26213.714.11-12; 1.26213.717.2; Fig. 14).

\subsection{Settlement structure of the Scythian Period settlement}

For a long time very little was known about settlements influenced by Scythian culture on the Great Hungarian Plain. This culture is known as the Alföld group or Vekerzug Culture in scholarly literature. During the preventive excavations of the last two decades, settlements dating to the period, sometimes composed of hundreds of features, were recovered one after the other. ${ }^{6}$ The new finds not only help archaeologists describe the inner structure of individual settlements, but also provide an opportunity to reconstruct the regional settlement structure of the Vekerzug Culture.

\footnotetext{
${ }^{6}$ KEMENCZEI 2009, 23-25.
} 
Due to the sacrificial find assemblage, ${ }^{7}$ the name Nagytarcsa should sound familiar to those who research the Hungarian Iron Age, although these were not the only Early Iron Age finds from the region. Thanks to field walking surveys, we have data on the Scythian Period occupation from several parts of Nagytarcsa. ${ }^{8}$ Without exception, these archaeological sites are all situated in a row, along the banks of the Szilas and Csincsa Creeks (Fig. 18). This scheme follows the settlement structure earlier observed in the Danube Bend area, ${ }^{9}$ in the Zagyva and Körös valley, ${ }^{10}$ as well as in the Middle Dniester region. ${ }^{11}$ Due to the difficulties associated with dating finds collected on the surface during field walking, and because of the mosaic-like quality of existing data, it does not seem possible to trace the changes that influenced the development of settlement structure patterns, or to sketch the Early Iron Age settlement structure of the broader area.

The nature of the preventive excavation conducted in the territory of Nagytarcsa, at Urasági-dülö, hampered efforts to get fully acquainted with the Iron Age settlement. Parts of two Scythian Period settlement features (Pit 26/26. and 551/581.) extended over the border of the excavation trench. Because of this it was impossible to excavate them in their entirety. Furthermore, five additional pits were subsequently disturbed by Roman Imperial Period (Sarmatian) settlement features.

Based on absence of any signs of fortification, as well as on the sporadic position of settlement features, it can be said that the Early Iron Age settlement of Nagytarcsa fits the model of the open air, village-like settlement type seen in the Vekerzug culture. ${ }^{12}$ This form of settlement became dominant over the entire territory of the Carpathian Basin from the beginning of the Ha D period. ${ }^{13}$ Analogies of this settlement pattern can be found in the area of the forested steppes, especially along the Middle-Dniester. ${ }^{14}$

The Scythian Period settlement of Nagytarcsa-Urasági-dülő was established next to a former watershed; Early Iron Age archaeological finds were not recovered further away from the Szilas Creek. This corresponds with data indicating the hydrological sensitivity of this culture. ${ }^{15}$ During the excavation the northern and eastern borders of the settlement were clearly defined, while the stream providing a physical frontier probably established the southern borders. In the western part of the site it was not possible to document the extent of the occupation zone, which is clearly indicated by the high density of settlement features. It is generally accepted, that the central, primary unit of the Vekerzug Culture's settlements is the semi-subterranean house, which is surrounded by settlement features of different size and function; together these formed a household unit. ${ }^{16}$ The uneven distribution, as well as the grouping of the settlement features in Nagytarcsa probably reflect distinctive areas of activity (Fig. 1). These areas can be identified as household units, although it is difficult to distinguish and define them. Similar settlement structure could be observed in the Scythian Period settlement found in the vicinity of Berettyóújfalu ${ }^{17}$ as well as in Iron Age villages of the Middle-Dniester valley. ${ }^{18}$ Amongst the archaeological phenomena found at Nagytarcsa, the only feature that can be identified as a building is the semi-subterranean structure $472 / 488$. Its rounded edges, rectangular shape, and its width of $350 \mathrm{~cm}$ fits the general description of building types of this archaeological era. Usually two or more postholes can be found within similar structures. These postholes form a simple, downward leading passage onto the pounded clay floor. ${ }^{19}$ The presence of construction must be considered in two additional cases (Feature 553/583. and 564/594.), because deep postholes were found on the bottom of both features. The analysis of semi-subterranean Celtic houses has demonstrated that the building type, as well as the construction of its superstructure, is affected by numerous factors. ${ }^{20}$ Considering the aforementioned points, the reconstruction of the features described above, which contain only a single posthole, presents several problems. Consequently, even the theoretical reconstruction of semi-subterranean Building 472/488 cannot be carried out completely.

The rounded or oval pits with cylindrical or bulging sidewalls that were found on the site were usually located near the semi-subterranean houses. It is assumed that they fulfilled some kind of economic function. ${ }^{21}$

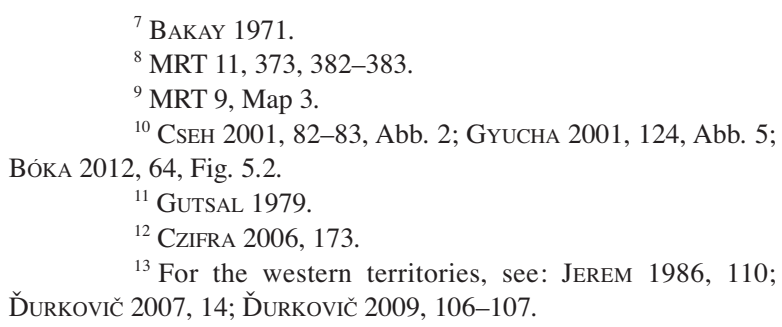

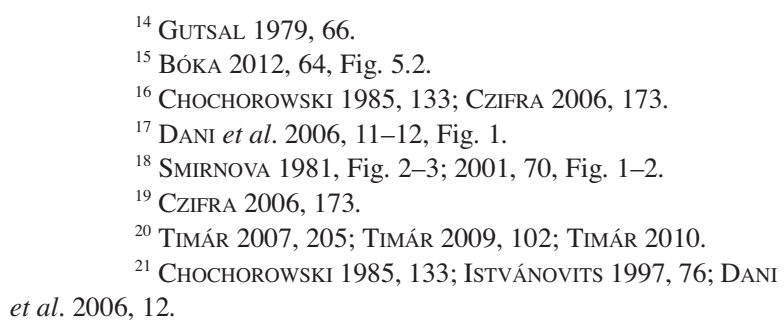


Amongst the excavated settlement features of Nagytarcsa only one oven was found (634/765). The number of openair ovens and hearths vary on every settlement in this archaeological period. Whilst these features appear abundantly in Salgótarján, ${ }^{22}$ such features appear only from time to time on one of the biggest settlements of this period located in the vicinity of Nyíregyháza. ${ }^{23}$ The oval, open-air ovens were usually situated further from the dwellings; their baking surface was well-plastered and lined with pebbles or ceramic fragments in order to aid heat retention. ${ }^{24}$ A lack of wells is a prominent feature at this site, a phenomenon that cannot be explained by the proximity of a watercourse. It is assumed that the wells are situated in the unexcavated part of the settlement that lies close to the bank of the creek.

\subsection{Evaluation of the finds}

Altogether 304 ceramic fragments and one burnt daub fragment were recovered from the Early Iron Age settlement, which is undoubtedly a poor assemblage. The traditional typological analysis of the ceramic repertoire was complemented by scientific examinations carried out on 44 ceramic fragments (see Chapter 2). Two different principles were considered during the selection of these samples: on the one hand, we aimed to cover the entire range of ceramics that could be distinguished by the traditional typological approach; on the other hand, samples were selected that would show different petrographic attributes during the macroscopic selection of the ceramics. We aimed to select more samples from those features which yielded more finds, while also examining the typical wheelturned and hand-formed vessel types of the Scythian potters, as well as ceramics assumed to be imports. Based on pottery production technology, the ceramic assemblage of the archaeological site can be divided into two major groups: hand-formed and wheel-turned wares. The technological and petrographic analyses of the ceramics supported this observation; however with the help of scientific examinations we observed combined ceramic production techniques as well. Based on these, we can refine our knowledge of Scythian Period ceramic production. The two above-mentioned groups include all four major vessel types (large, double-cone-shaped vessels, high-handled cups, bowls with inverted rims, and barrel or squat-shaped pots) of the Vekerzug Culture. ${ }^{25}$ However, numerous vessel and clay artefact types are missing from the recovered assemblage. Besides the vessel fragments that can be evaluated archaeologically, several rim and body fragments only hold information in the form of decorations and shape.

\subsubsection{Biconical pots}

The key feature of biconical pots is the body shape that resembles two cones. ${ }^{26}$ This shape is diversely emphasised by a carination running around the middle or the lower third of the body. According to certain views, this vessel form is more abundant in the northern and southern outskirts of the Great Hungarian Plain, than the barrel-shaped pots. ${ }^{27}$ Both the hand-formed and wheel-turned version of this type of vessel can be found in the settlements and cemeteries of Scythian Period populations of the Great Hungarian Plain. ${ }^{28}$ In addition, local varieties can be found within the Scythian heritage of Transylvania, of south-western-Slovakia, of Transdanubia, and along the Dniester and Dnieper rivers. ${ }^{29}$ Hand-formed biconical pots are usually black, however version with a black exterior and a brown or reddish-brown interior is also abundant. ${ }^{30}$ Researchers agree that this vessel type is rooted in local Late Bronze Period pottery traditions. ${ }^{31}$ This Iron Age vessel probably assumed its shape around the middle of the $7^{\text {th }}$ century BC. ${ }^{32}$ The latest examples of this style were found in La Tène contexts, dated to the $3^{\text {rd }}-2^{\text {nd }}$ century BC. ${ }^{33}$

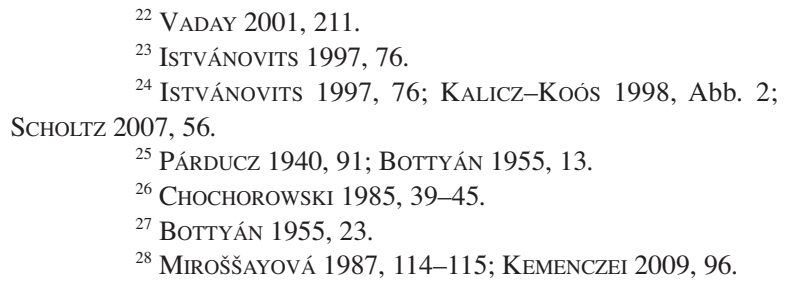

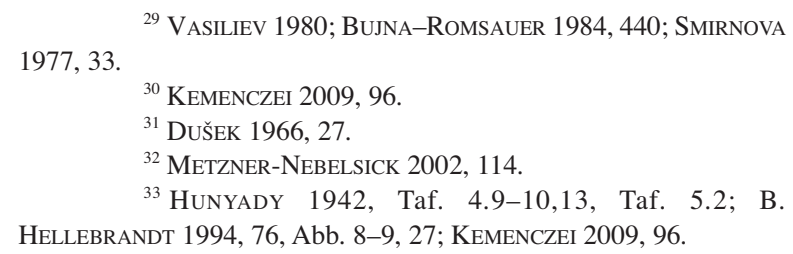


The analysed biconical pots (Fig. 9.2 and Fig. 16.6) found at our archaeological site were made from a variety of raw materials (Sample 3 on Fig. 23.1 and Sample 42 on Fig. 24.2), therefore they show the signs of technological variability. That said, only hand-formed versions were observed.

Biconical pots with vertical rims and almost cylindrical necks (Fig. 17.1) are not very abundant in this period. ${ }^{34}$ Their analogies are known from the settlement that came to light at Hernádvecse ${ }^{35}$ as well as from the cemetery of Törökszentmiklós. ${ }^{36}$ Most of the biconical pots have a slightly or more significantly everted rim. The analogies of the variant with a less everted rim (Fig. 9.1 and Fig. 11.1) are also known from Hernádvecse ${ }^{37}$ and from the Celtic settlement of Sajópetri. ${ }^{38}$ An analogy to the variant with a horizontally everted rim (Fig. 9.3) can be found at Fegyvernek. ${ }^{39}$ The edge of the rims is curved (e.g. Fig. 9. 2-3) or vertical (e.g. Fig. 9.1 and Fig. 11.1). The most abundant variant of biconical pots are decorated with four symmetrically arranged knobs, usually below or very near the carination on the vessel body (Fig. 16.7). Only hand-formed types of this variant are known. ${ }^{40}$ According to certain researchers, this vessel type is associated with the early phase of the Vekerzug Culture. ${ }^{41}$ The local varieties of these knobbed biconical pots are also abundant in this period in Transylvania, ${ }^{42}$ as well as in the Dniester and Dnieper regions. ${ }^{43}$

\subsubsection{Hand-formed barrel-shaped pots}

The barrel-shaped pots form the greatest part of Iron Age household ceramics. Currently only hand-formed versions are known. Even based on the ceramic petrographic examination carried out on the material of the site, only hand-formed barrel-shaped pots could be identified. Barrel-shaped pots can be found in both settlements and in cemeteries but their use cannot exclusively be associated with the Vekerzug Culture. Their local varieties can be found in the eastern Hallstatt culture populations ${ }^{44}$ and among the Celtic finds. ${ }^{45}$ The colour of the Scythian barrelshaped pots is usually brown or brownish-yellow. Their surface is frequently rough. Aside from the undecorated examples (Fig. 9.4,11, Fig. 12.1), these pots are commonly decorated with knobs, ribs and finger impressions or with a combination of the three. ${ }^{46}$ With regard to the entire ceramic assemblage from the site, barrel-shaped pots are the most abundant vessel types amongst the finds from Nagytarcsa. From a petrographic point of view they represent the most homogenous group, as they belong to the $3^{\text {rd }}$ petrographic group (for details see Subchapter 2.2.5). Analogies to the barrel-shaped pots with two or four symmetrically arranged knob decoration under the rim (Fig. 10.7, Fig. 11.6-7, Fig.15.13) are found at other settlements from the same period: for example at Gyál, ${ }^{47}$ at Jászfelsőszentgyörgy, ${ }^{48}$ at Kengyel ${ }^{49}$ and at Nyírparasznya. ${ }^{50}$ Analogies to the barrel-shaped pot with flat knob decoration are known from Hernádvecse, ${ }^{51}$ Békéscsaba, ${ }^{52}$ Szolnok-Zagyvapart, ${ }^{53}$ Tiszaigar ${ }^{54}$ and Besenyszög. ${ }^{55}$

Celtic Period specimens found at Endrőd, ${ }^{56}$ Sajópetri $^{57}$ and Sé ${ }^{58}$ are evidence of the longevity of this decoration type. One of the most abundant variants has finger impressions used as decoration around and below the rim (Fig. 10.2,8). Analogies to this pot variant are found at almost every site, ${ }^{59}$ for example at Fegyvernek, ${ }^{60}$ Gyál, ${ }^{61}$

${ }^{34}$ ChOchorowski 1985, Abb. 4.12.

${ }^{35}$ VERES 2008, P1. V.5.

${ }^{36}$ Csalog-Kisfaludi 1985, Abb. 1.13.

${ }^{37}$ VERES 2008, Pl. VI.

${ }^{38}$ SzABÓ 2007a, P1. II.2.

${ }^{39}$ CSEH 2006, Fig. 9.3.

${ }^{40}$ PÁrduCz 1955, T. VIII:1,5; ChOCHOrowski 1985, 42, Abb. 4.1.

${ }^{41}$ KemenCZei 2009, 96.

${ }^{42}$ VASILIEV 1980, 62-65.

${ }^{43}$ SMirnova 1977, 33, Fig. 3.3.

${ }^{44}$ Patek 1984, 67; GÁL-Molnár 2004, 179; StegmannRAJTÁR 2009, 79.

${ }^{45}$ SzABó et al. 2007; SZABÓ-TANKÓ 2007.

${ }^{46}$ Chochorowski 1985, 36; Kemenczei 2009, 96-97; KozUBovÁ 2013, 145-148.

${ }^{47}$ DiNNYÉs 2002, Fig. 4.8,12.

${ }^{48}$ CSEH 2008, Fig. 10.5,7,15, Fig. 11.3,7.
${ }^{49}$ CSEH 2009, Fig. 6.9, Fig. 7.20.

${ }^{50}$ CZIFra 2016, Fig. 5.4-5, Fig. 7.5, Fig. 9.2-3.

${ }^{51}$ VERES 2008, Pl. I.1.

${ }^{52}$ BÓKA 2007, Fig. 9.5-8.

${ }^{53}$ CSEH 1990, Fig. 9.2.

${ }^{54}$ CSEH-KrivecZKy 2001, Abb. 11.2-3; Abb. 13.6-7.

${ }^{55}$ CSEH 2005, Fig. 7.2-4.

${ }^{56}$ MenNa 2006, T. I.0455. It must be mentioned that the site of Endröd 19 is generally referred to as a Scythian Period settlement (e.g. CATTANi 1994; Guidi 1994; GENITO 2008, 354). Nevertheless, according to A. Menna's dissertation (2006), Iron Age settlement features contained both Vekerzug and Celtic type ceramics. Thus, Endröd 19 should be dated to the La Tène Pperiod, rather than to the Early Iron Age. ${ }^{57}$ SZABÓ 2007a, Pl. II.5,7.

${ }^{58}$ GÁl-Molnár 2004, Taf. 23.5, Taf. 30.12, Taf. 31.9,11.

${ }^{59}$ PÁRducz 1955, T. VII:1; CHOChorowski 1985, Abb. 3.4.

${ }^{60}$ CsEH 2006, Fig. 10.1,7, Fig. 11.3, Fig. 12.5,9,11.

${ }^{61}$ DinNYÉs 2002, Fig. 3.8, Fig. 5.12. 

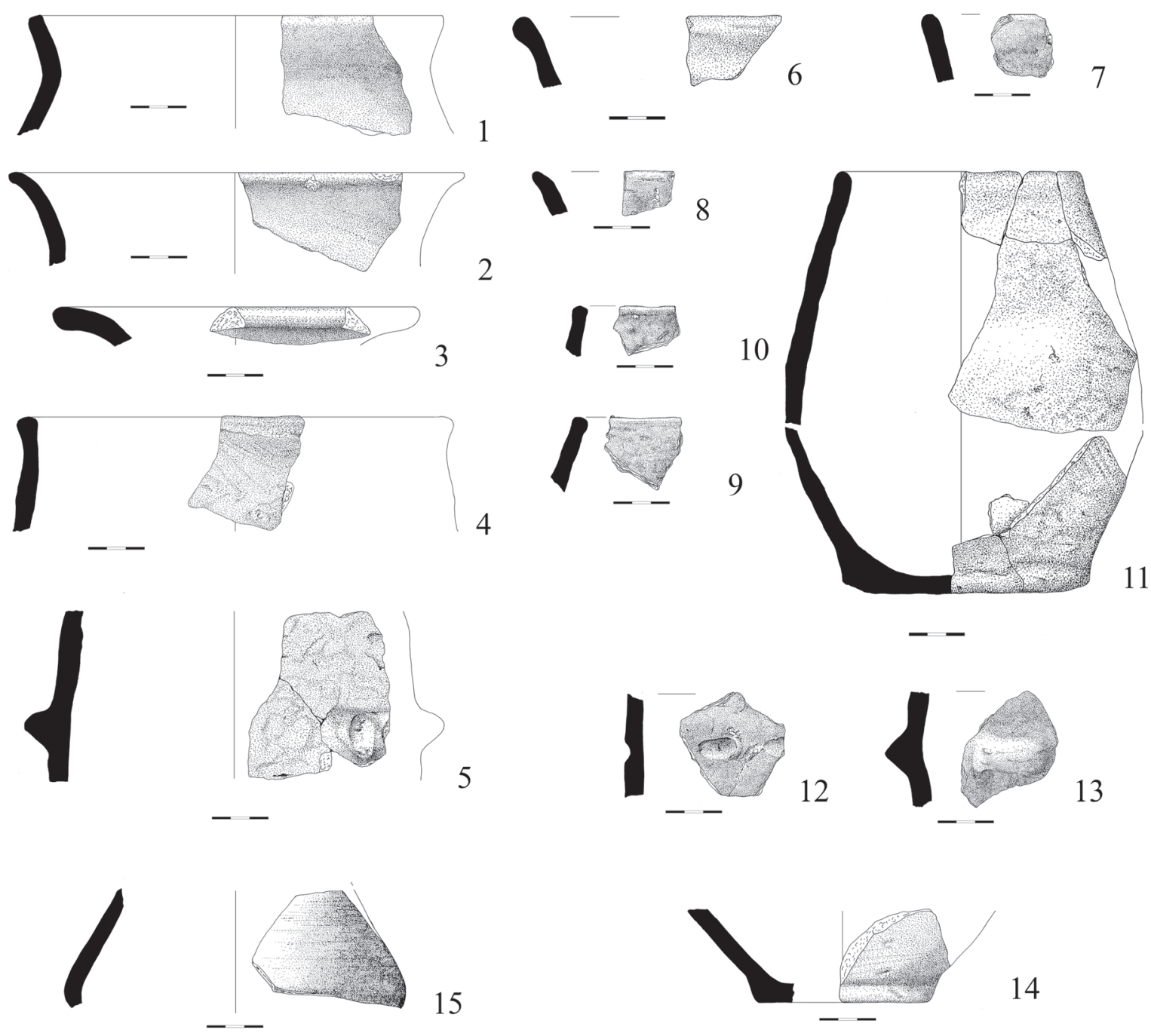

15
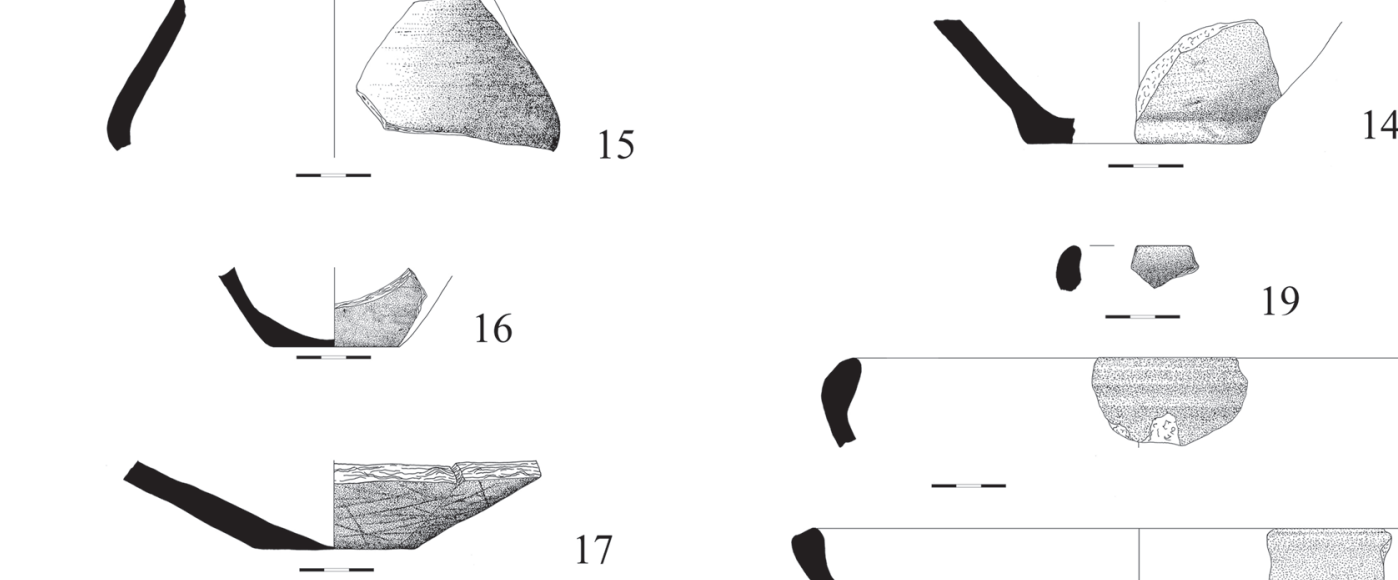

17
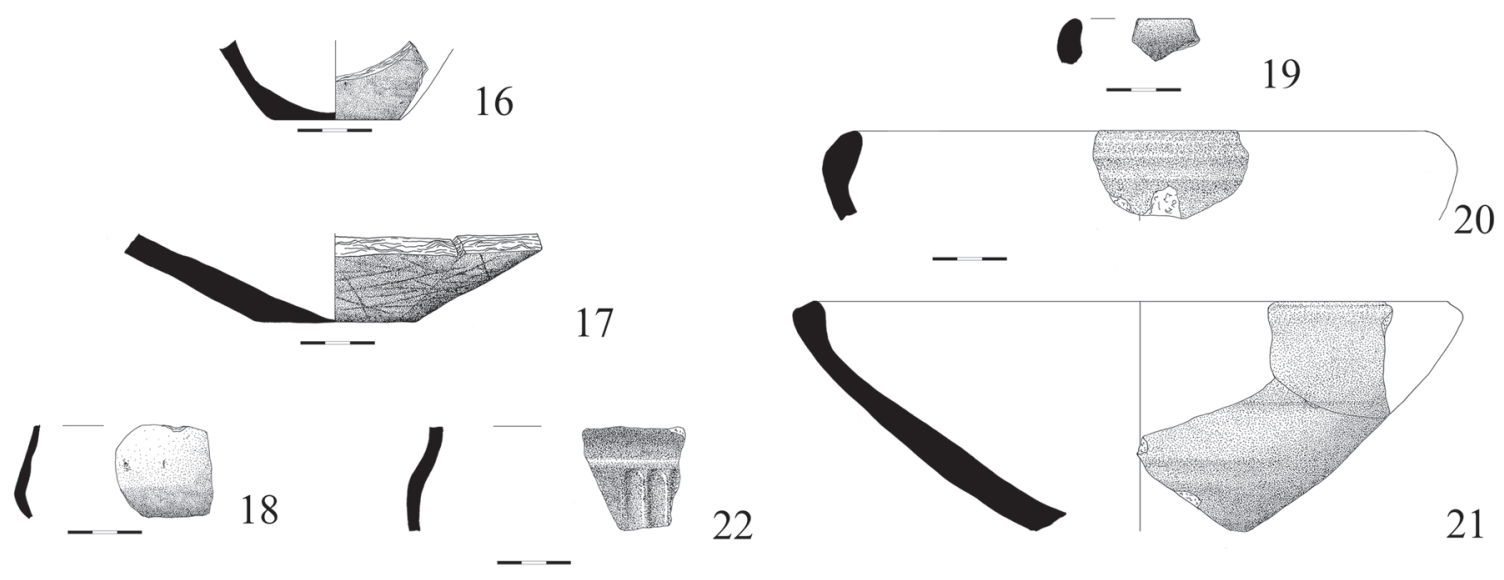

22
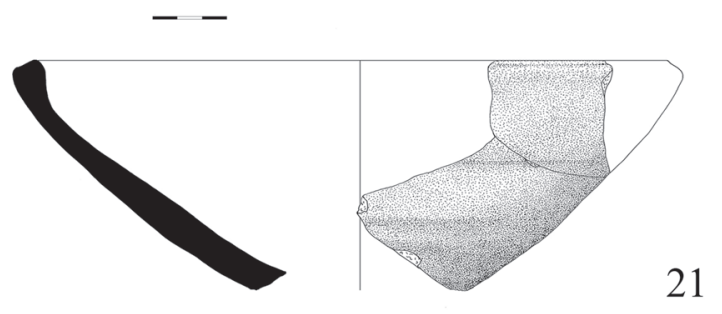

Fig. 9. Diagnostic ceramic finds from Pit 26/26. 
Hejőkeresztúr, ${ }^{62}$ Hernádvecse, ${ }^{63}$ at Jászfelsőszentgyörgy, ${ }^{64}$ at Mezőkövesd, ${ }^{65}$ at Nyírparasznya,${ }^{66}$ and at Polgár,,${ }^{67}$ just to mention the most important Vekerzug settlements. Although this is one of the most abundant vessel types in the household ceramic assemblage of the Hallstatt Culture, it seems to appear in larger numbers during the second part of the Ha D period. ${ }^{68}$ On the settlements of the Bosut group ${ }^{69}$ and in the territory of the forested steppe zone ${ }^{70}$ pots sectioned with finger impression decorated ribs are the leading finds amongst household wares. In the forested steppe zone these wares can be found on both open-air ${ }^{71}$ and fortified ${ }^{72}$ settlement types. The decoration even appears on pottery products of the Late Iron Age. ${ }^{73}$ The barrel-shaped pot with impressed knob decoration (Fig. 9.5; Fig. 13.11) is somewhat less abundant in the find assemblage of the Scythian Period. Similar pots can be found at Polgár-Homok-dülö, ${ }^{74}$ but sporadically analogies appear in the ceramic material of Hallstatt ${ }^{75}$ and Celtic ${ }^{76}$ settlements. The fragment registered under the inventory number 1.26213.581.19. (Fig. 14.10) can be identified as a formal variant of barrel-shaped vessels with two symmetrically and horizontally arranged elongated knob decorations. Analogies to this decorative type could only be found in the Hallstatt context of Trstené pri Hornáde/Abaújnádasd (SK) ${ }^{77}$ and of Lébény. ${ }^{78}$ Fragments registered under the inventory number 1.26213.441.7. and 1.26213.774.5. (Fig. 11.3; Fig. 16.5; Subchapter 2.4, Samples 11 and 43) can be classified within the group of vessels that are decorated with two elongated knob rows arranged horizontally under the rim (e.g. Bogdanovce/Balogd-Garbócbogdány, Čečejovce/Csécs, Dúbravka/Dobróka (SK), ${ }^{79}$ Hernádvécsee, ${ }^{80}$ Jasov/Jászó (SK), ${ }^{81}$ Mali Heivcii/Kisgejőc

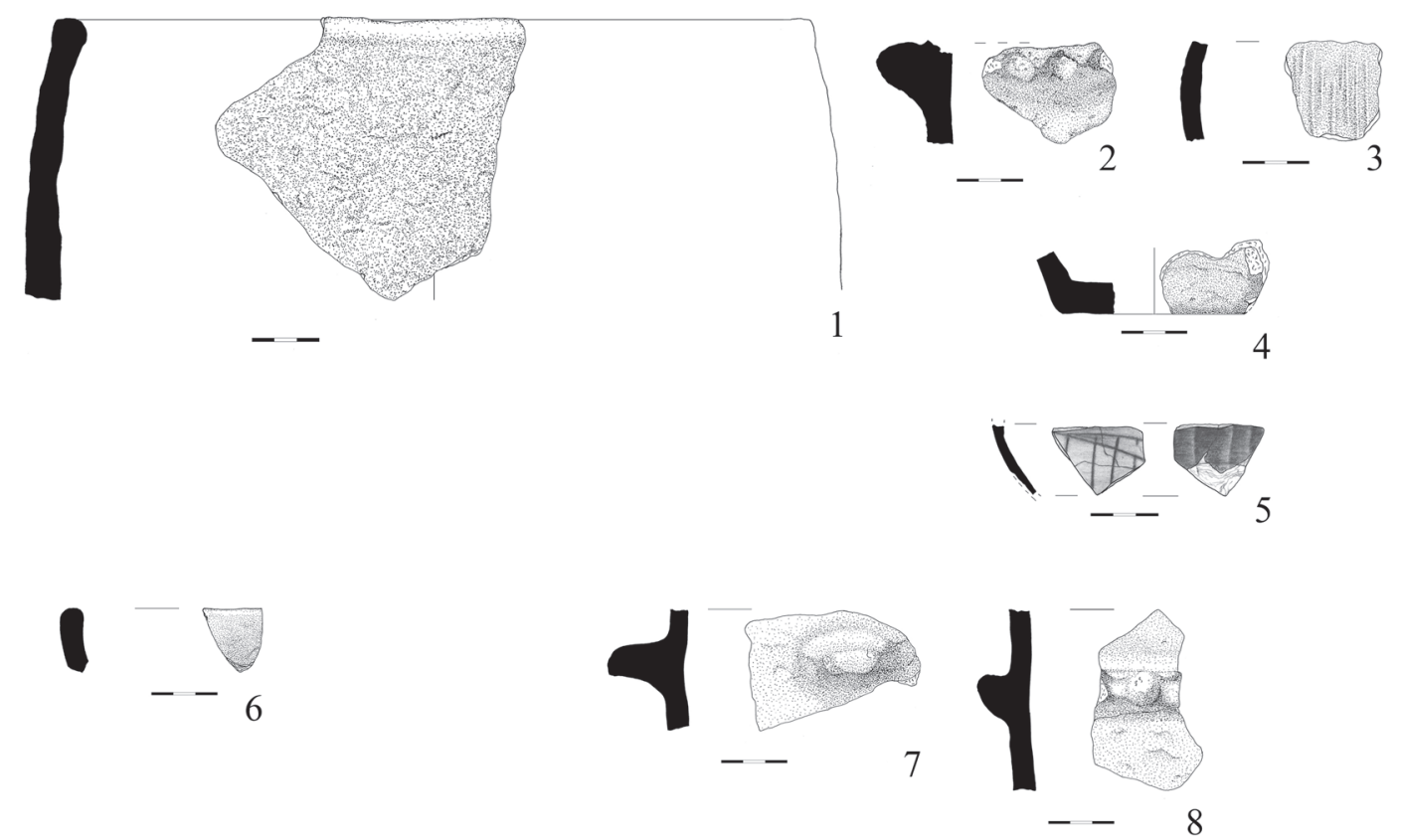

Fig. 10. Selected ceramic material from Pits 23/23. (1-5), 33/33. (6) and 39/39. (7-8)

${ }^{62}$ PÁRducz 1958, Tab. I.2,4-5.

${ }^{63}$ VERES 2008, Pl. II.4,5.

${ }^{64}$ CSEH 2008, Fig. 10.4, 6, Fig. 11.1,4-5.

${ }^{65}$ KalicZ-Koós 1998, Abb. 4.9,12,14, Abb. 5.7-10,12,15, Abb. 7.2,7, Abb. 10.16.

${ }^{66}$ CZIFra 2016, Fig. 3.5-6, Fig. 5.2.

${ }^{67}$ Veres 2003, 83, 86, Fig. 4.1,2, Fig. 8.1.

${ }^{68}$ JEREM 1981, 114, 122; KOVAČEVIĆ 2008, 56; SCHWELLNUS 2009, 249.

${ }^{69}$ Popović 1981, 28; VASIĆ 1987, 540-541.

${ }^{70}$ Ganina 1984,71

${ }^{71}$ Ganina 1965, Fig. 1.1,3, Fig. 3.2-8; Ganina 1984, Fig.
72 YaKOVEnKo 1968, Fig. 4; BessonOVA-RomanYUK 2004, Fig. 3.4, Fig. 6.1-5, Fig. 7.2,5,7-8.

${ }^{73}$ Gál-Molnár 2004, Taf. 22.1,13, Taf. 23.8; Menna 2006, T. VIII.0183, T. XI.0252, T. XII.0219, SZABÓ 2007a, P1. II.2.

${ }^{74}$ Veres 2003, 83, Fig. 3.4.

${ }^{75}$ KeMENCZEI 1977, Abb. 5.5.

${ }^{76}$ SzABó 2007a, Pl. V.8-9, P1. VII.11.

77 JUREČKO 1983, Fig. 7.6.

${ }^{78}$ ĎURKovič 2007, III. T. 1.

${ }^{79}$ MiroššAYoví 1987, T. XIII.8, T. IV.26, T. XI.7.

${ }^{80}$ Veres 2008, T. I.4,6.

${ }^{81}$ MiroššAYOVÁ 1987, T. I.1.

${ }^{82}$ Popovich 2006, Fig. 5.10.

${ }^{83}$ Bujna-Romsauer 1984, Taf. II. 15. 

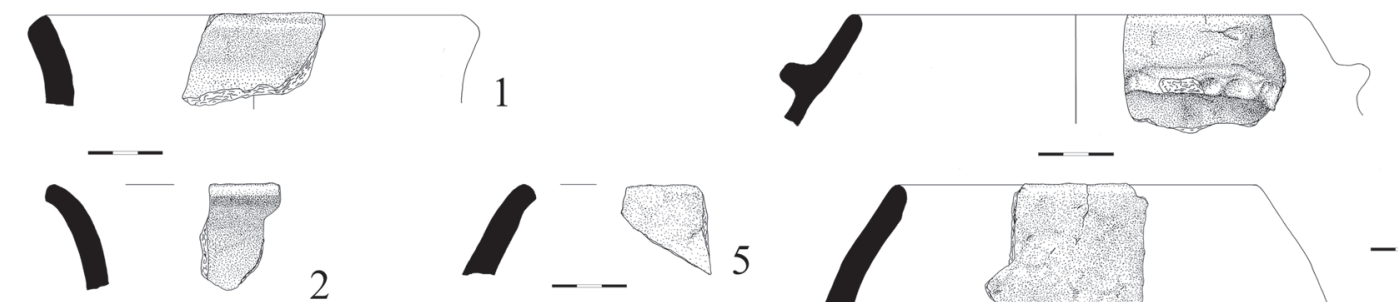

2
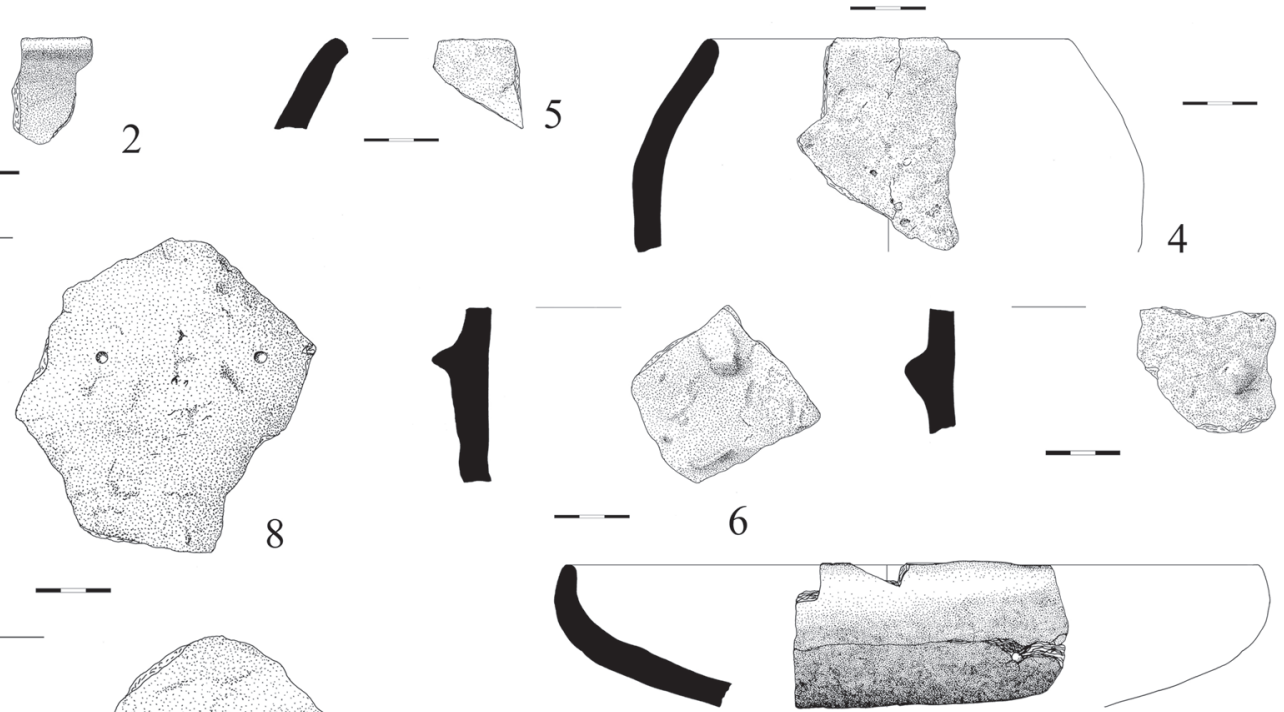

6

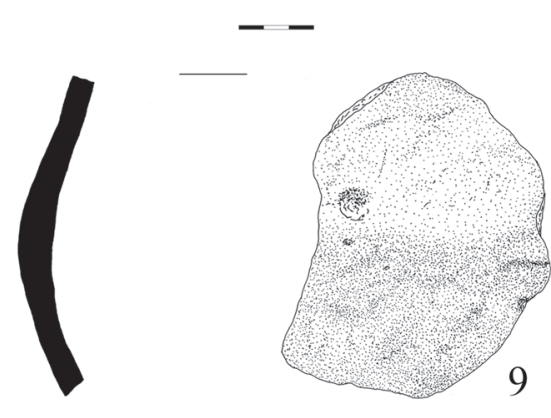

9

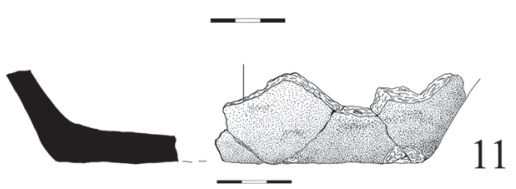

11
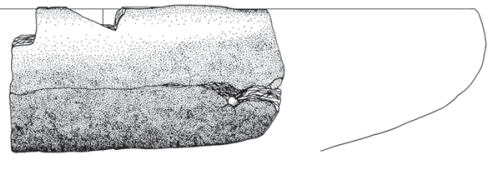

Fig. 11. Ceramic finds from Pit 429/441

(UA) ${ }^{82}$ Hoste/Kisgeszt (SK) ${ }^{83}$ Kushtanovitsye/Kustánfalva/Kuštanovice (UA),${ }^{84}$ Lébény, ${ }^{85}$ Nitra/Nyitra (SK) ${ }^{86}$ Salgótarján, ${ }^{87}$ Sanislău/Szaniszló (RO) ${ }^{88}$ and Tápiószele) ${ }^{89}$ This form appears both in Transdanubia and in Slovakia in the Late Hallstatt context ${ }^{90}$ but can also be found in the Late Iron Age material as well. ${ }^{91}$ Numerous analogies to barrel-shaped pots decorated with simple, lenticular impressions running horizontally under the rim (Fig. 9.12) are known form Scythian Period settlements, ${ }^{92}$ from Hallstatt sites ${ }^{93}$ as well as from La Tène settlements. ${ }^{94}$

${ }^{84}$ Popovich 2006, Fig. 20.9.

${ }^{85}$ ĎURKOVIČ 2007, 26, V. T. 3.

${ }^{86}$ ROMSAUER 1993, T. II. 7.

${ }^{87}$ VADAY 2003, Fig. 2.6.

${ }^{88}$ NÉMETI 1982, Abb. 16.1, Abb. 17.12.

${ }^{89}$ PÁRDUCZ 1966, Pl. LV.1-2.

${ }^{90}$ Jerem 1986, T. 3; Miroššayová 1987, 117; MiroššAYOVÁ 1994, 48.
${ }^{91}$ Guidi 1994, Fig. 3.2; MenNa 2006, T. XXXVI.0392; SZABÓ 2007, Pl. LI.8.

${ }^{92}$ CSEH 2006, Fig. 6.5; CSEH 2008, Fig. 10.12; KALICZKoós 1998, Abb. 10.7; CZIFRA 2016, Fig. 7.1.

${ }^{93}$ GÁL-MolnÁr 2004, Taf. 6.2; Taf. 12.6; GróH 1984, Abb. 5.14; ĎURKovič 2007, T. IV.1; KeMENCZeI 1977, Abb. 5.9.

${ }^{94}$ Menna 2006, T. XVI. 380, T. XXII.0908. 


\subsubsection{Flowerpot-shaped pots}

The appearance of flowerpot-shaped pots (Fig. 10.1, Fig. 14.4-5) is substantially less frequent than that of the barrel-shaped variants. They are typically more abundant in the Upper Tisza region ${ }^{95}$ and in the Kuštanovice Culture. ${ }^{96}$ The petrographically examined samples from Nagytarcsa (Sample 16 and possibly Sample 19 in Subchapter 2.2.1.) are hand-formed and were made from different raw materials. The most prevalent variant is decorated with ribs sectioned with impressions ${ }^{97}$ Analogies to this stylistic form come from the sites of Nyirparasznya ${ }^{98}$ and Törökszentmiklós. ${ }^{99}$ Items in the find material of the Bosut group ${ }^{100}$ and the specimens found in the Hallstatt settlement near Zbelava (HR) ${ }^{101}$ suggest that the flowerpot-shaped pots can be found in the entire Carpathian Basin in varying numbers during the Iron Age.
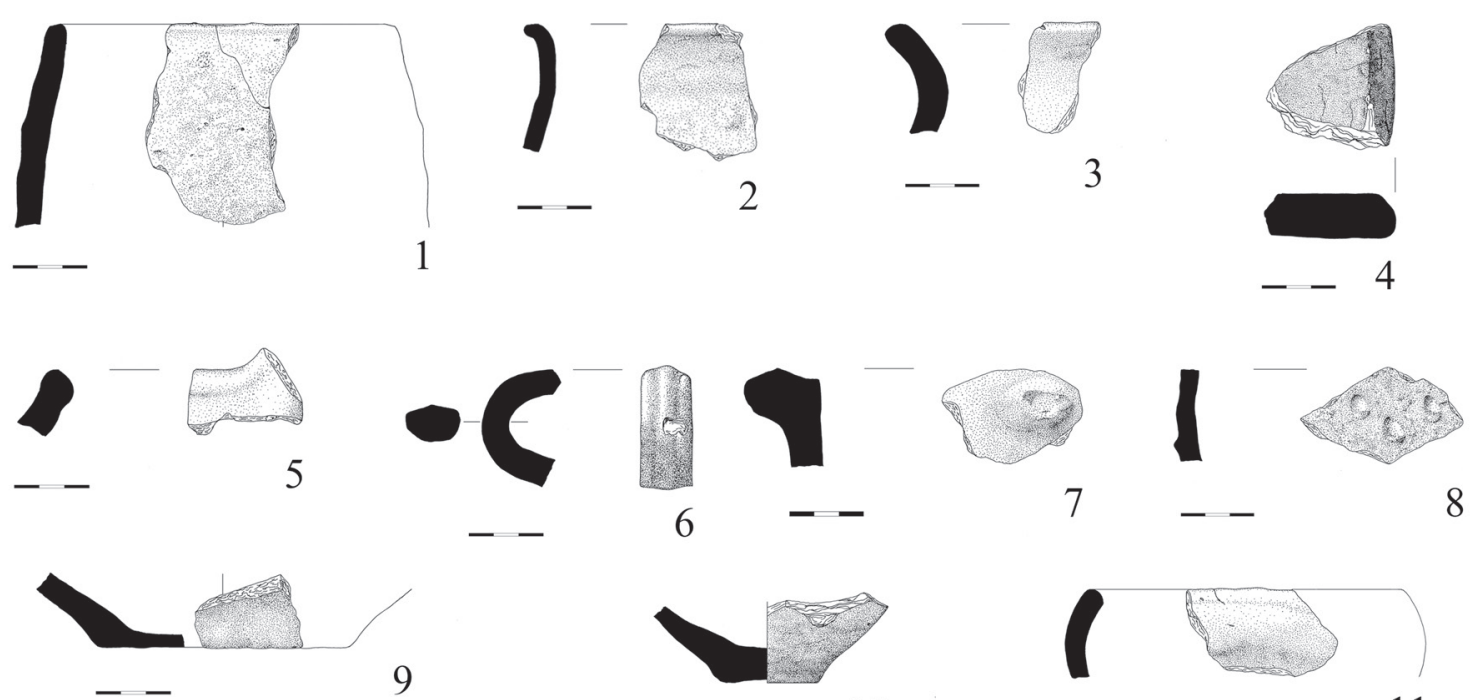

7

8
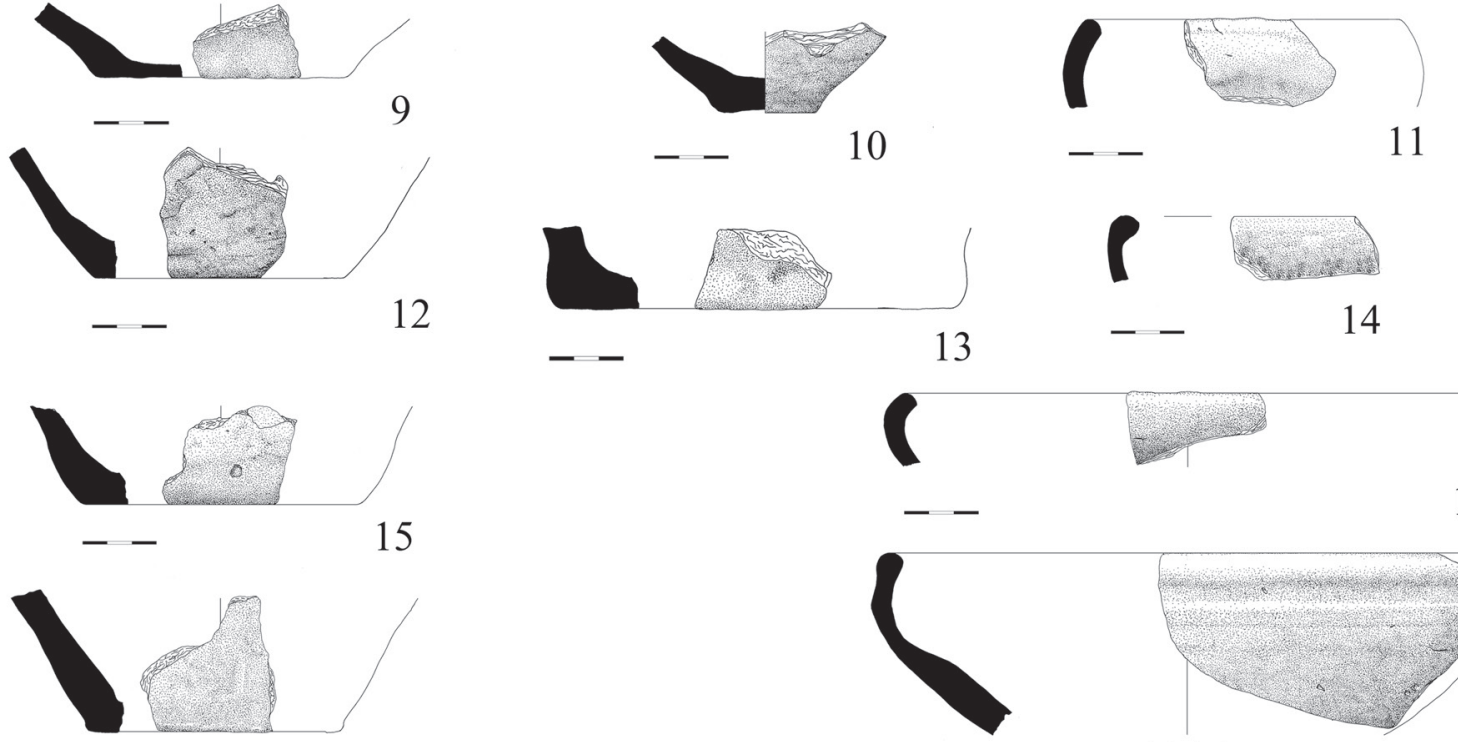

$-$

12

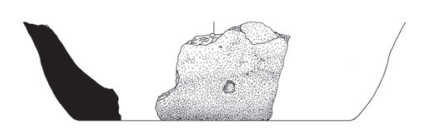

15

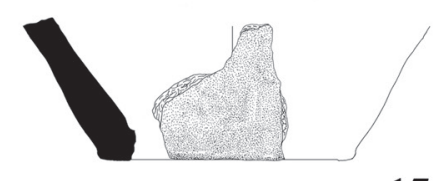

$-$

17

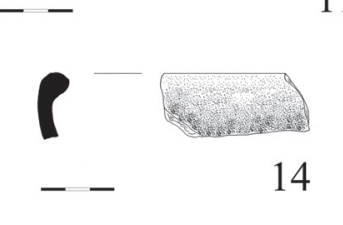

11

14

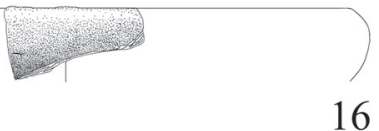

Fig. 12. Diagnostic ceramic finds of Structure 472/488.

\footnotetext{
${ }^{95}$ KeMENCZEi 2009, 96.

${ }^{96}$ Popovich 1997, 88

${ }^{97}$ Chochorowski 1985, Abb. 3.4; Kemenczei 2009, 96.

${ }^{98}$ CZIFRA 2016, Fig. 3.4-5, Fig. 9.1.
}

\footnotetext{
${ }^{99}$ Csalog-Kisfaludi 1985, Abb. 3.1.

${ }^{100}$ Popović 1981, 28.

${ }^{101}$ KovaČEVIĆ 2008, T. 2.2, T. 3.9.
} 


\subsubsection{Bowls with inverted rim}

Hand-formed and 3 wheel-turned vessel fragments were unambiguously identified as bowls with inverted rims in the find material of Nagytarcsa. In addition a further 11 fragments may possibly belong to this group. Both technological and petrographical examinations underline that the hand-formed variants are prevalent and only one of the samples examined proved to be wheel-turned (see Chapter 2, Fig. 15. 17, Sample 34 on Fig. 20.2). The bowl with inverted rim is one of the most abundant vessel types of the Vekerzug Culture. It can be found in both settle-
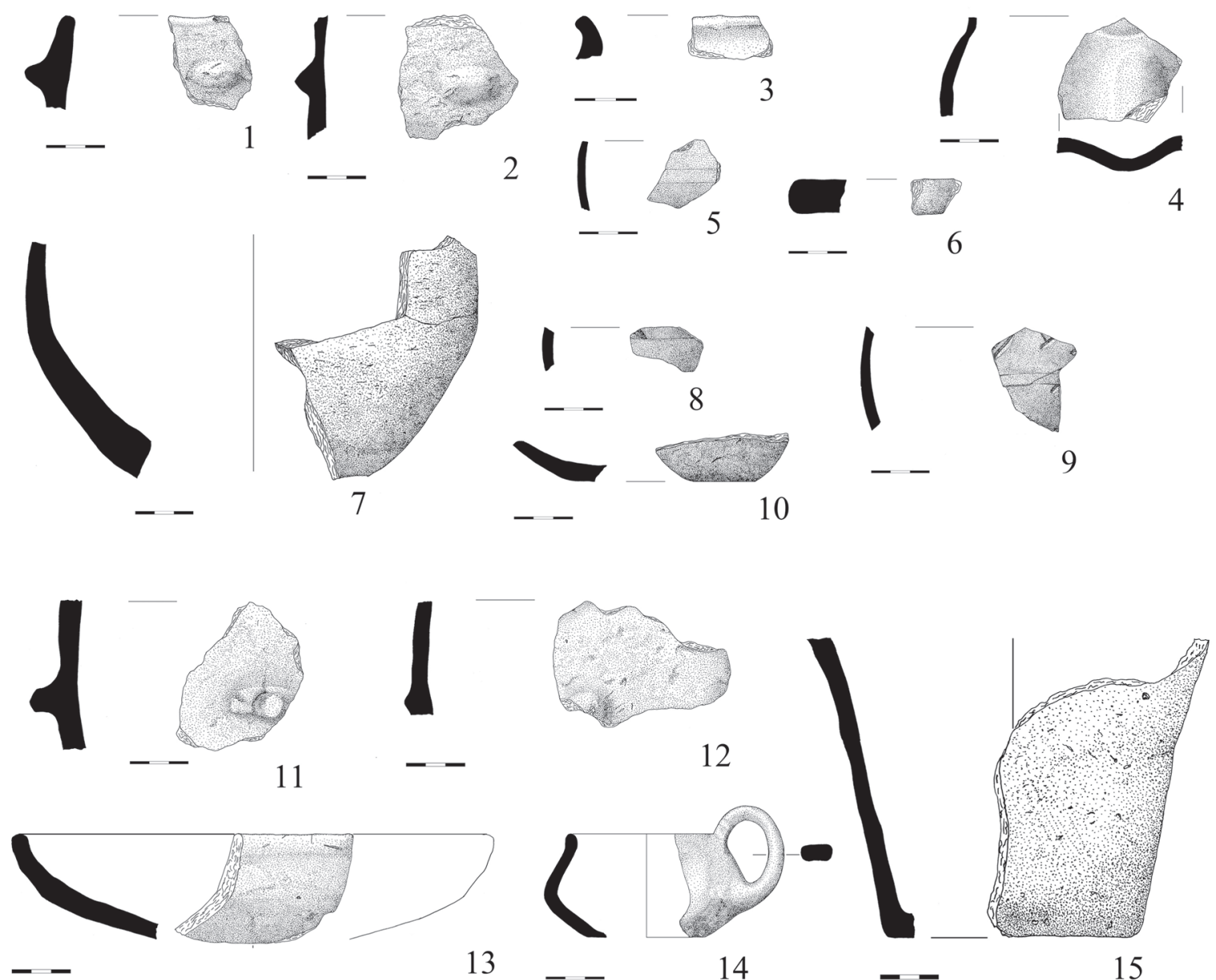

13

14

15
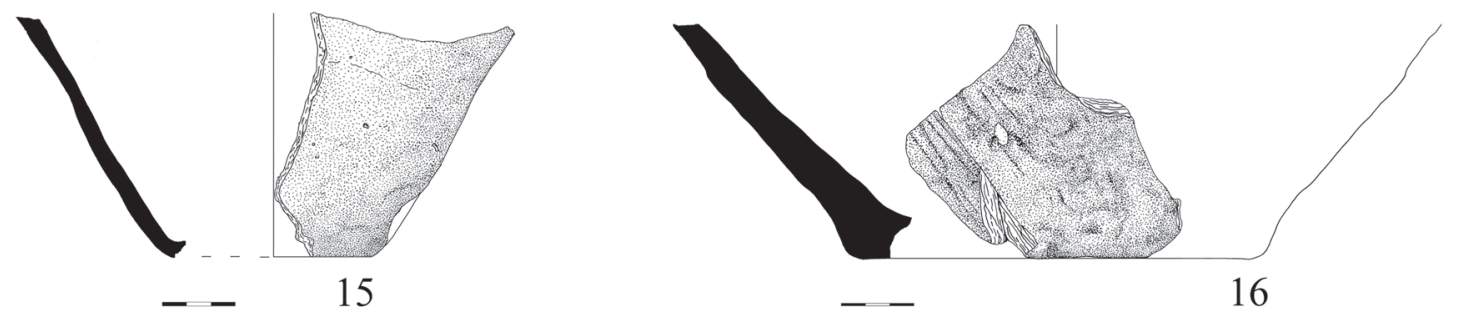

16

Fig. 13. Characteristic ceramic material from Pits 545/575. (1-6), 547/577. (7-10) and 549/579. (11-16) 

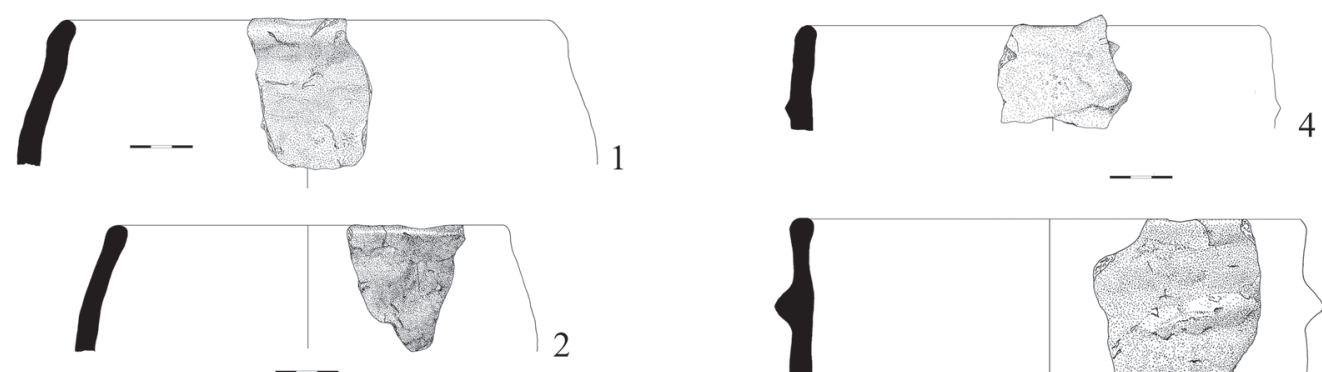

$a_{-\ldots}$
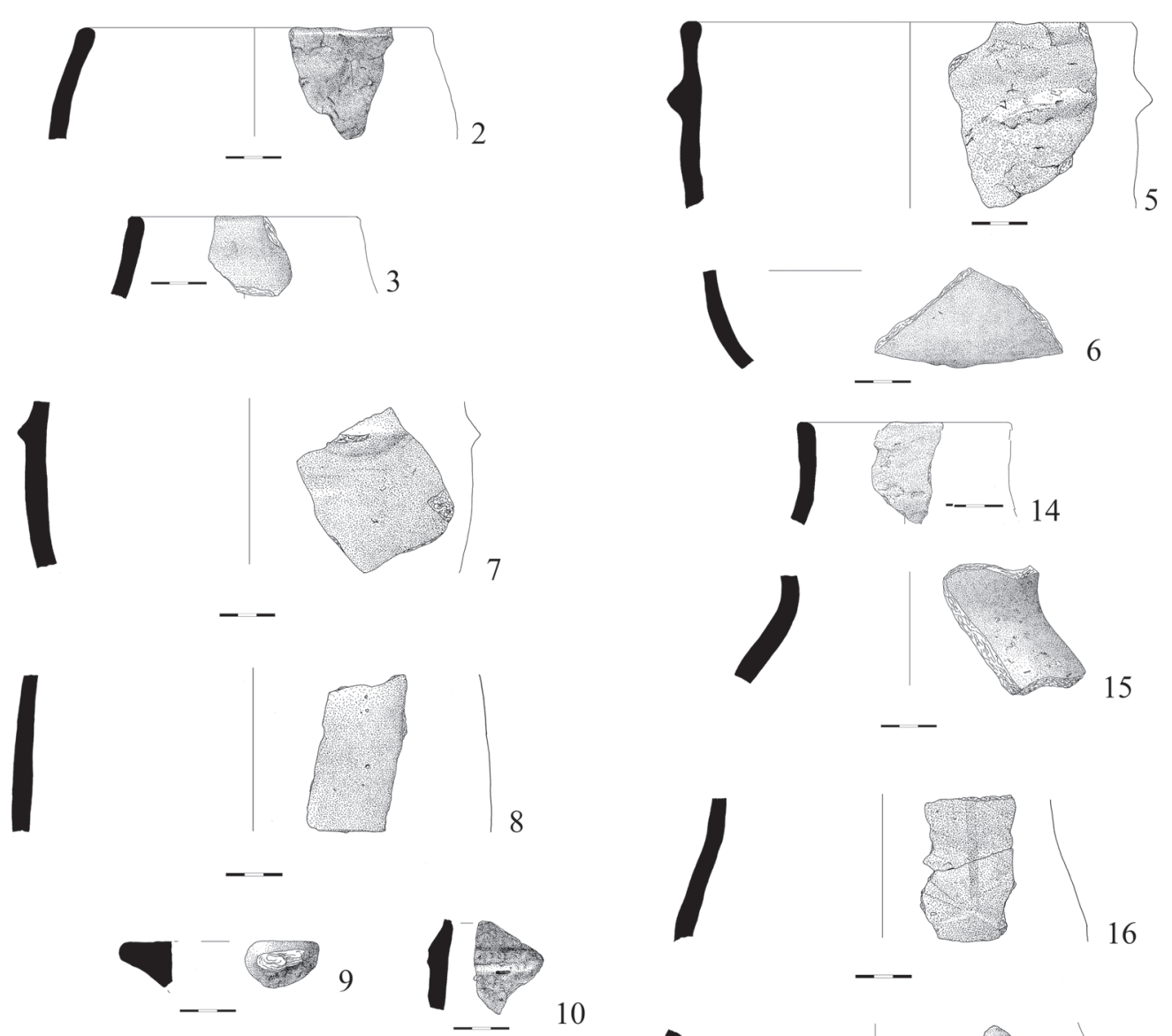

8
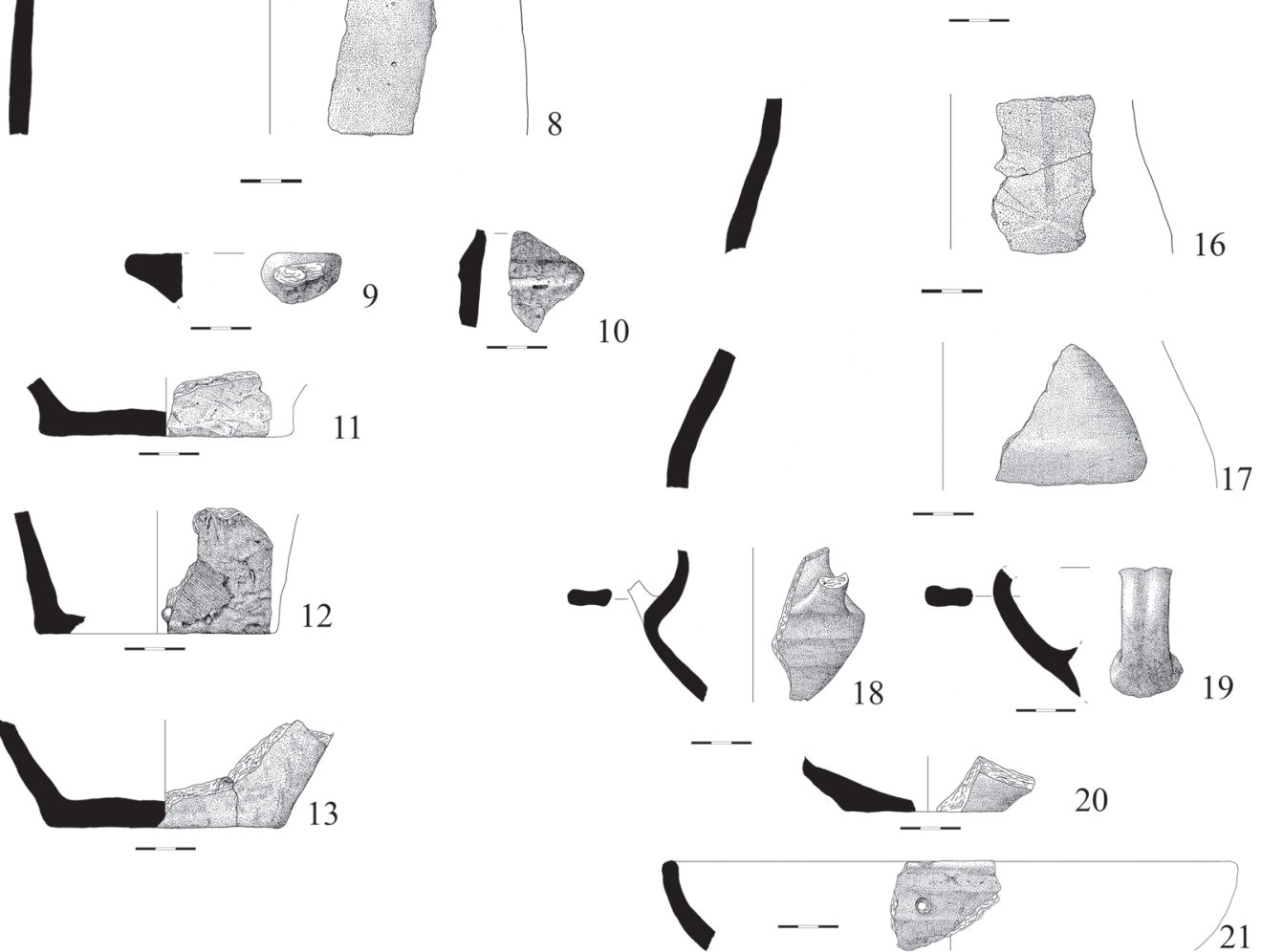

Fig. 14. Selected ceramic material from Pit 551/581. 

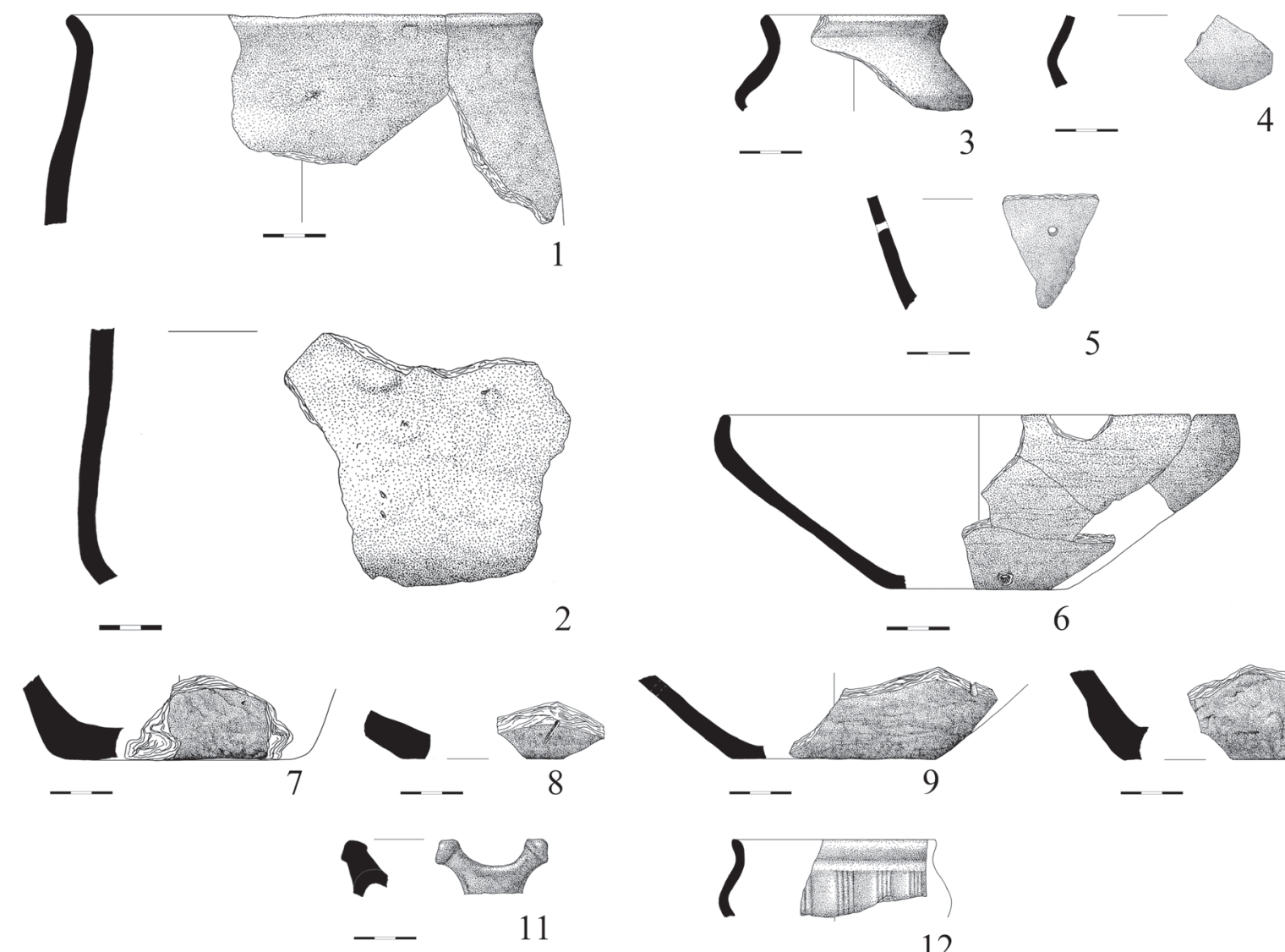

$--5$

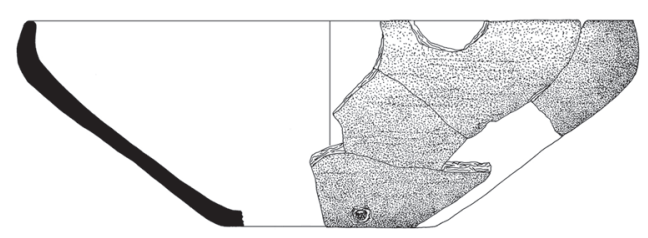

- - 6
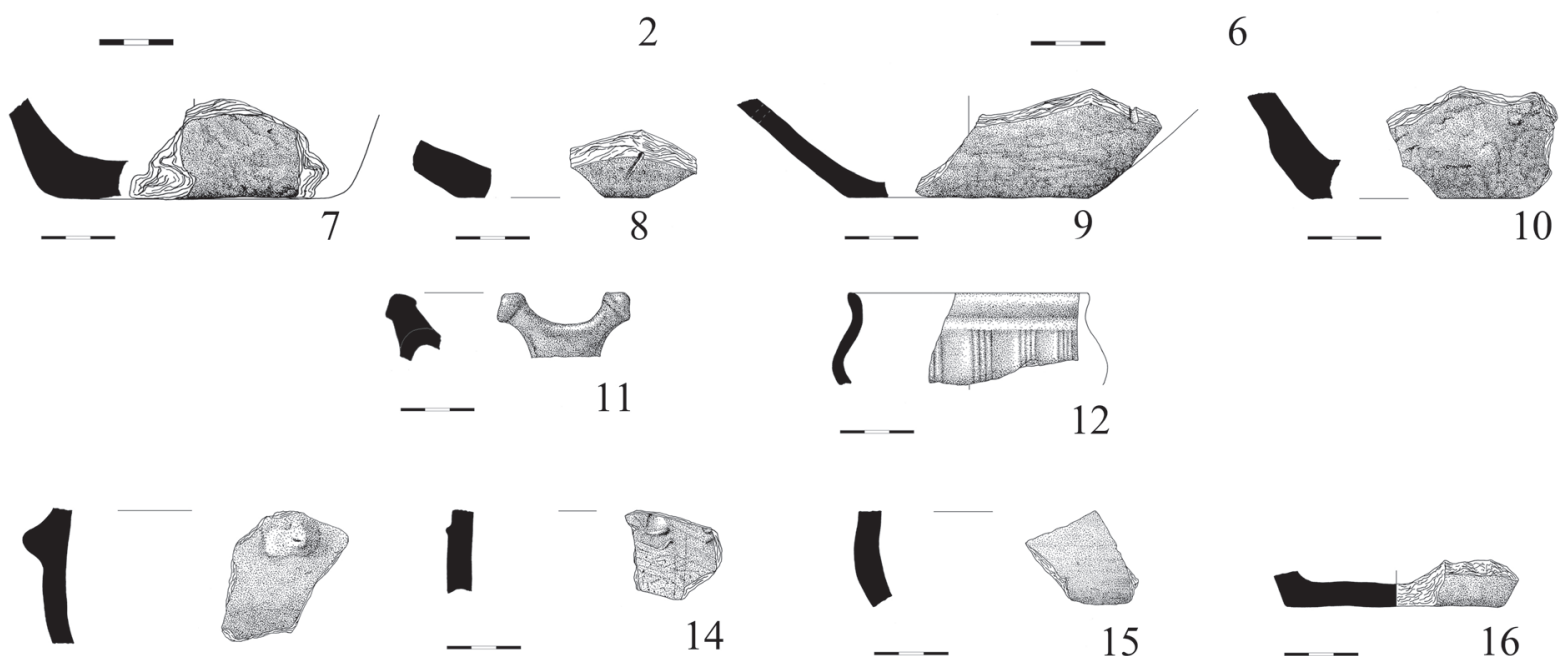

14

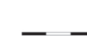

9

13

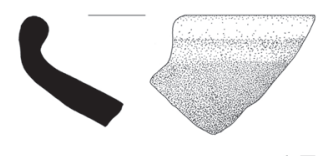

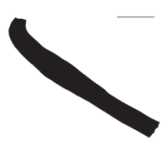

17

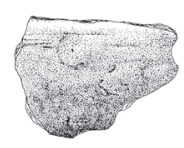

18

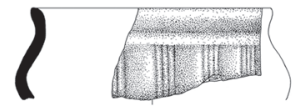

12
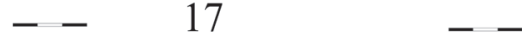

Fig. 15. Selected ceramic material from Features 553/583. (1-12), 563/59. (13-16) and 605/718. (17-20)

ments and in cemetries. ${ }^{102}$ The colour of the bowls is exceptionally diverse: it varies from blackish dark brown to a creamy brown tone. The items usually show signs of fire clouding. From the petrographical point of view, the raw material of the bowls found at Nagytarcsa is very diverse. The petrograph examination demonstrated the use of grog as temper for two bowls. The matrix and the composition of the ceramics, as well as the grain size category of their components, are similar to the raw materials. In light of the present results and of the petrographic examinations carried out earlier on Bronze Age ceramics it can be suggested that potters used similar ceramic types (derived from

${ }^{102}$ ChOChorowski 1985, 32; KemenCZei 2009, 97. 
false firing) for tempering, and not vessels made from different raw materials. The surfaces of the bowls found in the find assemblage are smoothed, which fits well with our knowledge of bowls with inverted rims. The form of the bowl with inverted rim probably evolved during the Bronze Age $\mathrm{e}^{103}$ and expanded over huge geographical areas in the Iron Age. ${ }^{104}$ It is not surprising therefore that this form is prevalent among the settlement finds of the WesternPodolian Scythian groups ${ }^{105}$ which show considerable similarity with those from the Iron Age Great Hungarian Plain. Based on the edge of the bowl rim (thinning, thickening, rounded, angular), on the angle of the rim, as well as on the decoration types, several variants can be distinguished. The semi-spherical bowls (Fig. 12.11, Fig. 13.13; Subchapter 2.4; Sample 14 on Fig. 23.4 and Sample 37 on Fig. 24.1) which are very abundant in this period ${ }^{106}$ should be emphasized here. The characteristics of this bowl form are the following: the rim is only slightly inverted, making it almost vertical, whilst the foot part is often profiled. Analogies of the semi-spherical shaped bowls can be found at numerous Scythian Period settlements. ${ }^{107}$ The faceting visible on the rim of the bowl (Fig. 9.20) can be traced back to local, Late Bronze Age traditions. This unambiguously points to the survival of the local Late Bronze Age population. The spiral channelled decoration and the faceting, which is limited to the rim, is typical of the Upper-Tisza region of Northern-Hungary in the Bronze Age, but it can be seen in Pre-Scythian and Scythian finds as well. ${ }^{108}$ Bowls with faceted rims are known from the Scythian sites of Hernádvecse, ${ }^{109}$ Gyál ${ }^{110}$ and Nyáregyháza. ${ }^{111}$ The thinning of the rim's edge (Fig. 11.13, Sample 10 on Fig. 23.3; Subchapter 2.4) can be seen on vessels of the Hallstatt Culture as well. ${ }^{112}$ Deep bowls are very typical in the find assemblages of the Vekerzug Culture (Fig. 15.6, Sample 22 on Fig. 23.7). ${ }^{113}$

Perforation in hand-formed bowls (Fig. 14.21) were observed earlier at other sites (e.g. Michalovce and Ebes), ${ }^{114}$ but there is no agreement regarding the function of the perforations. Based on ethnographic evidence and examples, some attribute the origin of the holes to the repairing of cracked bowls. Others identify the perforated bowls as hanging vessels. ${ }^{115}$ At Berettyóúffalu the unambiguous aim was to extend the lifespan of a jug cracked at its rim, whilst at Békéscsaba it was used to repurpose a cracked, barrel-shaped pot for pulling water. ${ }^{116}$

\subsubsection{Cups and jugs}

The cup type with a vertical or slightly outward curving rim with a bulging belly and with a handle looping over the rim (Fig. 13.14) is a universal vessel form from the Carpathian Basin in the Late Bronze Age ${ }^{117}$ It is the most common in Pre-Scythian times. ${ }^{118}$ In the Scythian Period the wheel-turned cups were more common than the hand-formed variants. ${ }^{119}$ The cups and jugs subjected to petrographic examination were made from the finest raw materials. Both hand-formed and wheel-turned types could be identified, and some of them were made using a combined technique (see Subchapter 2.2.2).

\subsubsection{Lids}

Fragments of a small, flat lid were recovered from Building 472/488. and from Pit 545/575. (Fig. 12.4, Fig. 13.6). After reviewing the relevant scholarly literature it was revealed that this type of artefact, which can be divided into two formal variants, was largely left out of consideration in previous summaries. The first type is composed of flat and discoid-shaped lids. The rim of this type tapers conically in most cases, allowing the lid to be

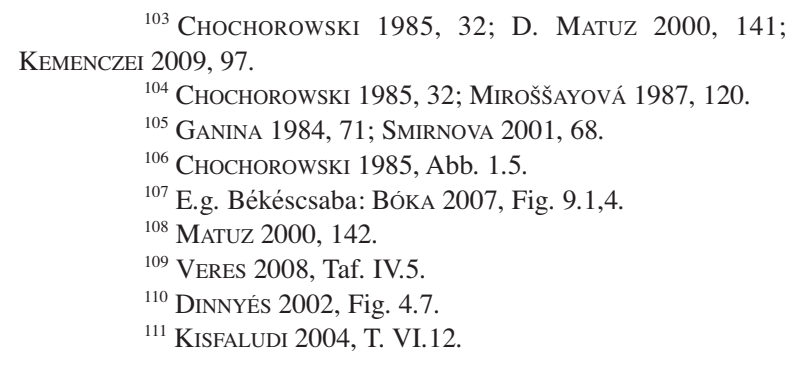

${ }^{112}$ GÁL-MolnÁr 2004, Taf. 6.5, Taf. 11.5.

${ }^{113}$ KozUBOVÁ 2013, 153.

${ }^{114}$ ČIlinská 1959, T. II.8; CZIFRA 2006, Abb. 2.12.

115 BóKA 2007, 120-123, Fig. 12-13; Kozubová 2017, 415, Tab. IV:4, V:1.

${ }^{116}$ DANI et al. 2006, 12; BÓKA 2007, 120, Fig. 7.2.

${ }^{117}$ KeMENCZEi 1984, 69.

${ }^{118}$ KEMENCZEI 1989, 66.

${ }^{119}$ DUŠEK 1966, 26; RoMSAUER 1993, 16. 

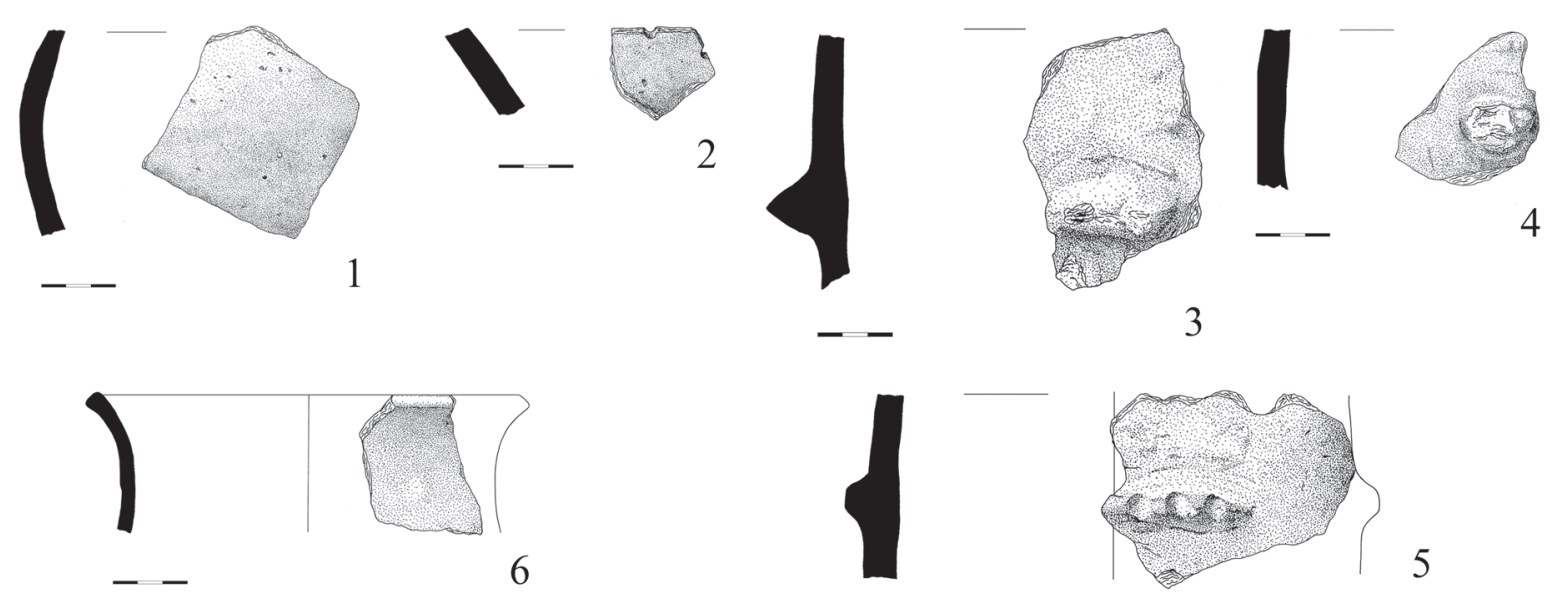

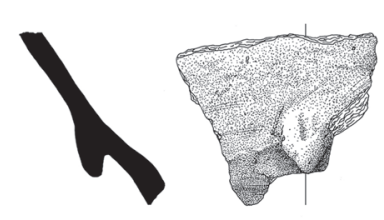

-

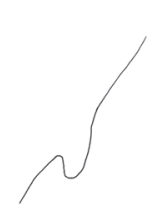

7

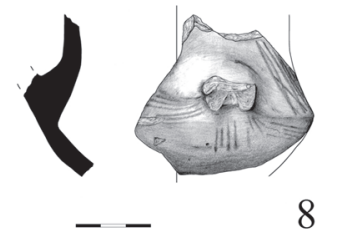

8

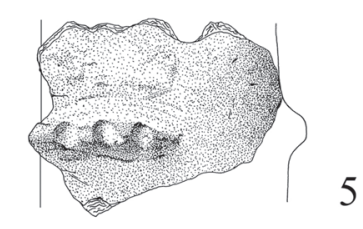

5
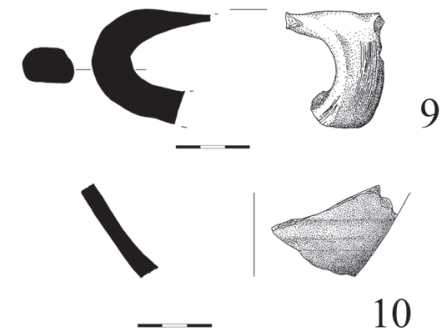

10

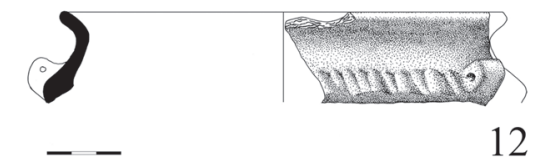

12

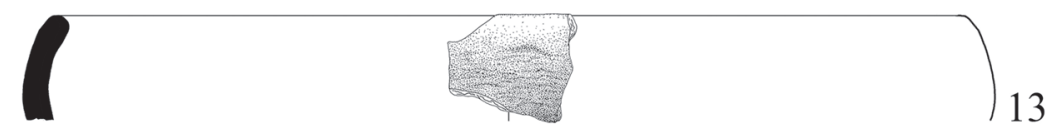

4

$-$
14

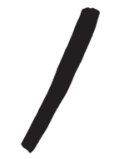

$-$

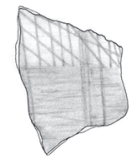

15
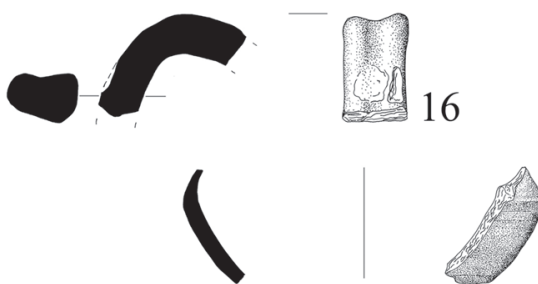

17

Fig. 16. Characteristic ceramics from Features 564/594. (1-2), 564/774. (3-12), 634/765. (13-15) and 634/766. (16-17) 


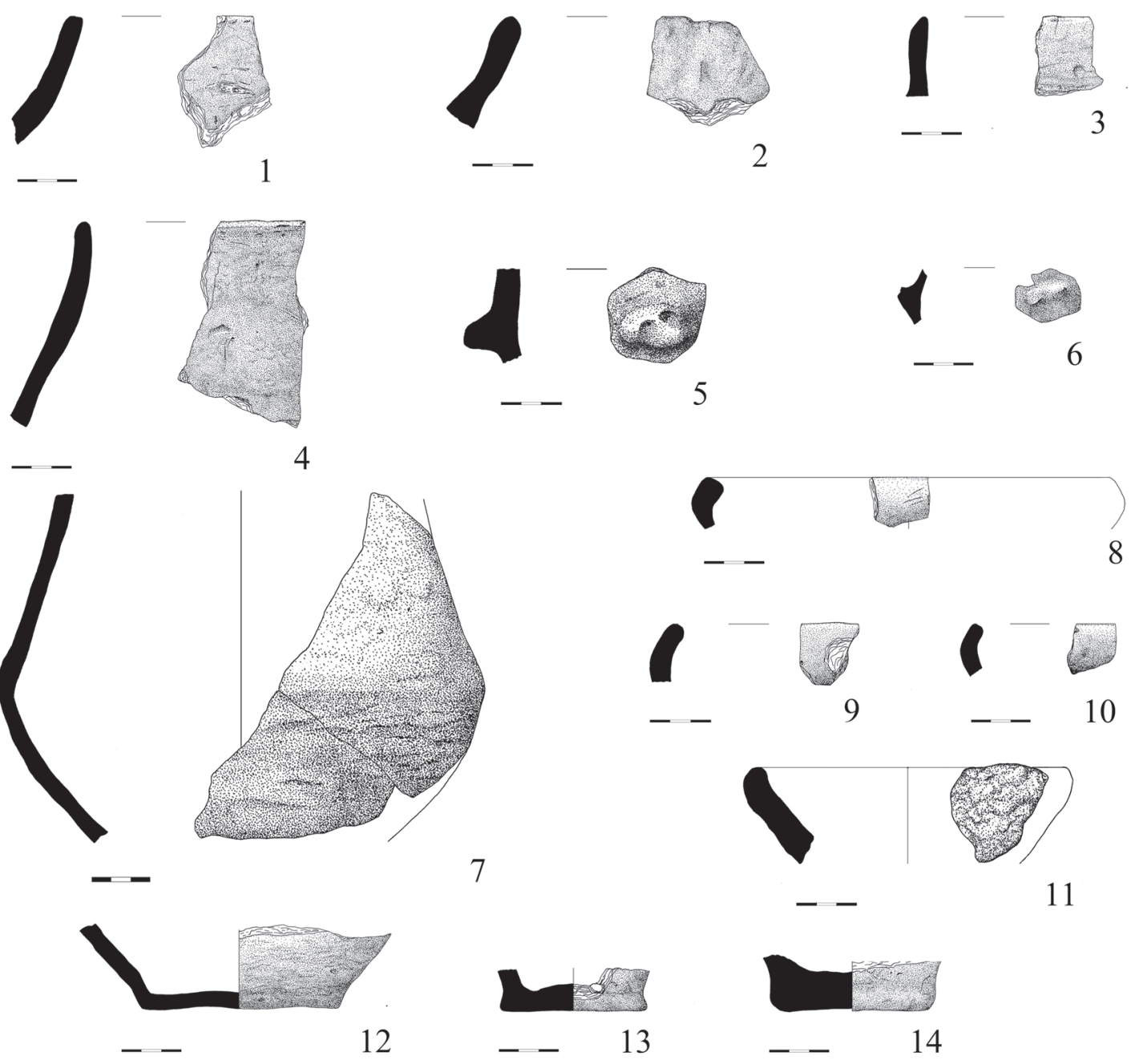

Fig. 17. Scythian Age stray finds from the site

easily placed inside the mouth of the vessel. The other type is composed of small, truncated cone-shaped, bowl-like lids. Discoid-shaped lids similar to those found at Nagytarcsa were brought to light at Cămin/Kálmánd (RO), ${ }^{120}$ at Lužianky/Sarlókajsza (SK), ${ }^{121}$ at Mezőkövesd-Mocsolyás, ${ }^{122}$ at Nitra/Nyitra (SK), ${ }^{123}$ at Nyírparasznya ${ }^{124}$ and at Polgár-Homok-dülő. ${ }^{125}$ Based on my observations the discoid-shaped lids can primarily be found in settlements, whilst the bowl-like lids seem to be exclusively associated with cemeteries. Nevertheless, based on observations from cemetery excavations, simple bowls were also used as lids. ${ }^{126}$ This explains the low ratio of lids within the excavated ceramic assemblage. The discoid-shape lids are widely used in the Kuštanovice Culture, ${ }^{127}$ and among the Scythian type cultures of the forested steppe zone. ${ }^{128}$ Analogies to the lids are also found in the La Tène ceramic repertoire of the Great Hungarian Plain. ${ }^{129}$

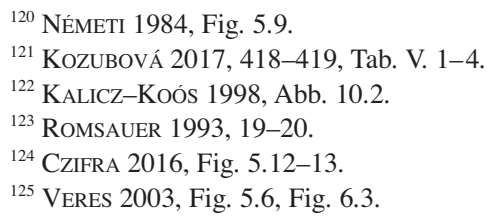

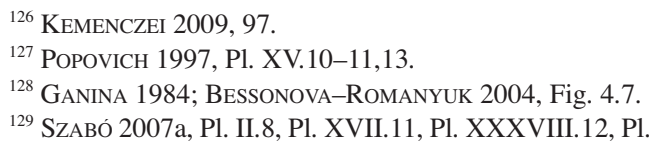




\subsubsection{Wheel-turned cups and jugs}

Amongst the specimens that were not subjected to petrographic analysis numerous wheel-turned, highhandled cups and jugs were found (Fig. 9.15, Fig. 14.18, Fig. 15.3-4, Fig. 16.8,17). These are considered to be some of the most characteristic vessel types from the Scythian Period on the Great Hungarian Plain. ${ }^{130}$ The colour of these vessels is almost always grey, the raw material that they were made from is well levigated, they are properly fired, and the wheel marks are usually detectable on their inner surface. ${ }^{131}$ Only a fraction of cups and jugs subjected to petrographic analysis were created using a wheel-turned technique. This contrasts with the less important wheelturned vessels although there were a significant number of cups and jugs made using a combined technique (Subchapter 2.4; Samples 1, 26, 28, 39). The examined vessels were not tempered; very fine-grained, or occasionally levigated raw material was used to produce them (see Subchapter 2.2.1). The rim of the wheel-turned cups are usually slightly everted; the only fragment that could be examined from this point of view has an obliquely cut-off rim. The arched and net-like burnished decorations (Fig. 16.8) on the wheel-turned cups and jugs have only few analogies among the Scythian Period finds. It can be imagined that their takeover and utilisation was influenced by external effects (of the Hallstatt culture). ${ }^{132}$

The difference between the Early Iron Age wheel-turned cups made in the Carpathian Basin and in the Balkan Peninsula refers to the different relations to Greek traditions of the pottery manufacture of the two territories. ${ }^{133}$ As for the Iron Age wheel-turned cups found in Transcarpathian, Transylvanian and the Transdanubian regions, they can be interpreted as import wares from the territory of the Vekerzug Culture. ${ }^{134}$ Numerous grave and settlement finds refers to the survival of this form in the La Tène Period after the appearance of the Celts in the eastern part of the Carpathian Basin. ${ }^{135}$

\subsubsection{Wheel-turned bowls}

The form and distribution of the wheel-turned bowls corresponds to those of the hand-formed types, ${ }^{136}$ which is the result of a mixture of local formal traditions and technological innovation. Based on petrographic analysis, the wheel-turned bowls are primarily characterized by very fine-grained raw materials (see Subchapter 2.2.2). The antecedents of the wheel-turned bowl type, with a strongly inverted shoulder and an inverted rim that does not thicken at its edge, could have originated in the Bronze Age. ${ }^{137}$ Based on petrographic analysis wheelturned bowls played a lesser role at the settlement (see Subchapter 2.2.2). The fragment registered under inventory number No. 1.26213.718.1. (Fig. 15.17, Sample 34 on Fig. 20.2; Subchapter 2.4) belonged to a wheel-turned bowl with a rounded, inverted rim. ${ }^{138}$ Similar vessels can be found on most Scythian settlements (e.g. Békéscsaba, Hernádvécse, Gyál, Mezőkövesd, Jászfelsőszentgyörgy). ${ }^{139}$ These types of bowls are considered to be one of the most common variants; ${ }^{140}$ similar ones can be found at Greek colonial settlements outside the Carpathian Basin ${ }^{141}$ and in the forested steppe zone. In Eastern-Slovakia bowls with globular rims occur alongside Vekerzug type bowls, which usually appear in Late Hallstatt contexts; ${ }^{142}$ this type of bowl can also be found at Celtic settlements in the eastern part of the Carpathian Basin. ${ }^{143}$

${ }^{130}$ Chochorowski 1985, 35, Abb. 2.1-2; Сhochorowski 1996, 116, Abb. 2; RoMsaUer 1991, Fig. 3.3.

${ }^{131}$ LENGYEL 1964, 26.

${ }^{132}$ Incidentally, the graphite decoration became more uniform and the lattice pattern more abundant in the Ha D2 Period of the Hallstatt Culture (PATEK 1984, 67-68; ROMSAUER 1996; 438).

${ }^{133}$ ROMSAUER 1991, 361.

${ }^{134}$ Miroššayová 1987, 123; Kemenczei 2009, 104; KemencZeI 2010, 120-121.

${ }^{135}$ ZIRRA 1976, 783; MARÁZ 1981, 106.
${ }^{136}$ DUŠEK 1966, 26.

${ }^{137}$ CSEH 2001; GYUCHA 2002, 63; BÓKA 2007, 119-120.

${ }^{138}$ ChOChOROWSKi 1985, Abb. 1.3.

${ }^{139}$ BÓKA 2007, Fig. 8.5; VERES 2008, T. 3; DinNYÉs 2002,

Fig. 4.1; KAlicZ-Koós 1998, Abb. 6.2; CSEH 2008, Fig. 8.12.

${ }^{140}$ ROMSAUER 1991, 361.

${ }^{141}$ AlEXANDRESCU 1978, Fig. 34.790-791,795.

${ }^{142}$ MirošŠAYOVÁ 1987, 120, T. VIII.6, T. XI.10-11.

${ }^{143}$ GuIdi 1994, Fig. 4.2-3; MenNa 2006, T. XIII.0334; SzABÓ 2007a, Pl. XLVII.9; Pl. LV.3,5. 


\subsubsection{Vessels representing the influence of the Hallstatt Culture}

Several 'foreign' ceramic fragments were recovered at Nagytarcsa. Analogies to these imports can primarily be found west and north of the Danube, in the territory of the Hallstatt culture. The black-coloured pots, cups and small bowls with graphite-coated and graphite-burnished surfaces (Fig. 9.22, Fig. 15.12; Subchapter 2.4, Sample 4 on Fig. 20.6 and Sample 25 on Fig. 21.2) belong to this group. Very similar examples were found in Sopron, Tokod and Hoste/Kisgeszt (SK) in late Ha D contexts. ${ }^{144}$ The strongly carinated vessels with short oblique or vertical grooved decoration on their shoulders, represent characteristic features from the second part of the Ha D Period. ${ }^{145}$ The graphite lattice pattern (Fig. 9.2,22, Sample 8 on Fig. 23.2; Fig. 13.4, Sample 13 on Fig. 21.1; Fig. 15.11, Sample 27 on Fig. 20.7; Fig. 16.15, Sample 37 on Fig. 24.1) is either abundant on their interior or on their exterior

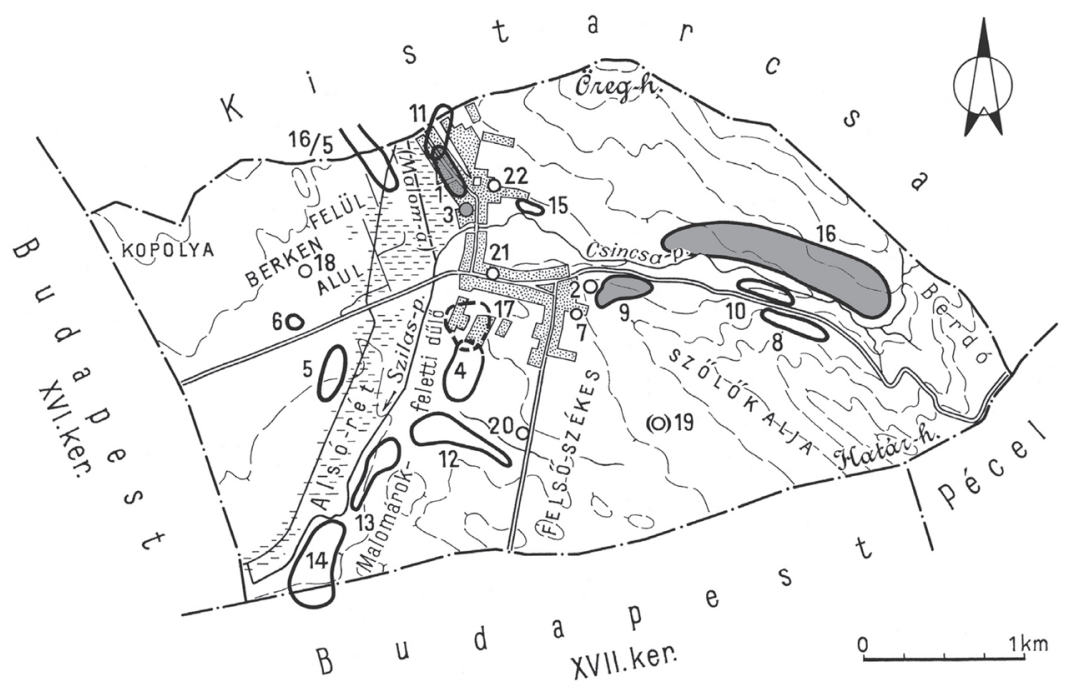

Fig. 18. Archaeological sites in the vicinity of Nagytarcsa (Scythian Age locations are marked with filled signs).

1: L. Kossuth Str. (Zubor-hegy); 3: Orvosi rendelő (Zrínyi Str. 38); 9: crossroad of G. Sztehló and Rákóczi Streets; 16: Urasági-dủlő (after MRT 11)

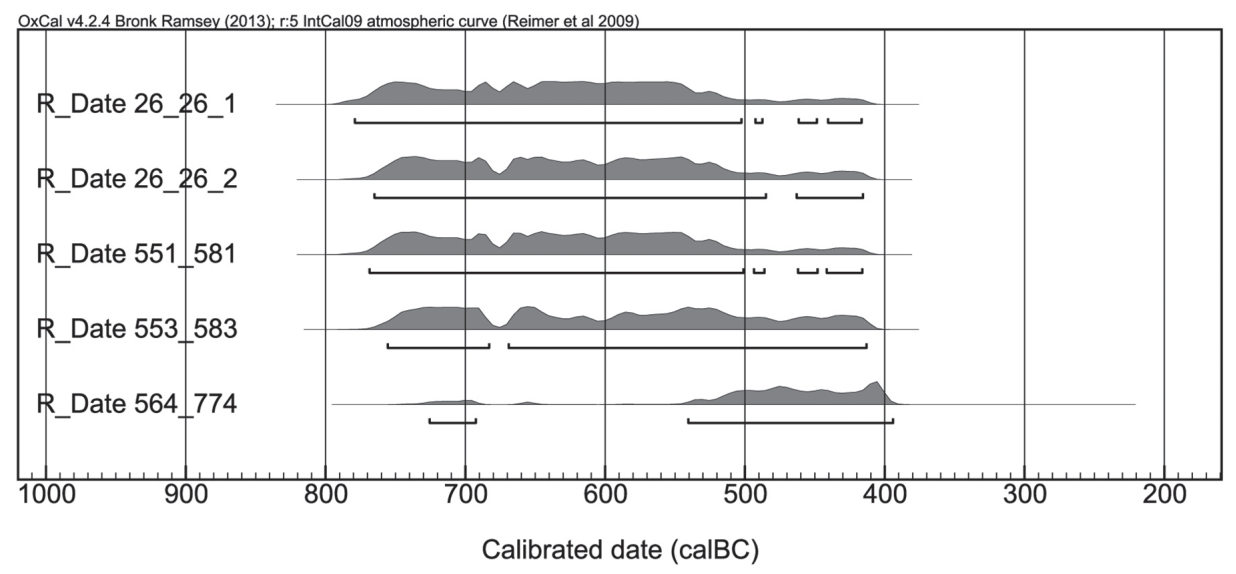

Fig. 19. Calibrated intervals of the measured samples

${ }^{144}$ JeRem 1981, Abb. 15.8; PATEK 1984, Taf. 19.11; BujnaROMSAUER 1984, T. III.5. Similar sherds are known from Early Iron
Age settlements near Valkó and Verseg in county Pest (MRT 11, 541, 569, T. 28.3-4)

${ }^{145}$ PATEK 1984, 67, Abb. 19.5-10; JÁKY 2016, Fig. 1. 
surfaces. ${ }^{146}$ Similarly formed vessels were found and published from Scythian Period settlements at Gyál and Dunavecse. ${ }^{147}$ Lattice patterns also occur in the find material of Mezőkövesd-Mocsolyás. ${ }^{148}$ The antecedents of graphite-polished surfaces and graphite paint on Hallstatt ceramics, can be traced back to Urnfield Culture traditions. ${ }^{149}$ The results of the petrographic and XRD analyses carried out on the finds of Nagytarcsa do not exclude the use of graphite before ceramic burning either (see more details in Subchapter 2.2.5). Moreover, since graphite does not adhere well to dry or fired vessels these practices were probably not applied by prehistoric potters. ${ }^{150}$ Since there is no natural source of graphite in the Carpathian Basin, the graphite nuggets found at Iron Age settlements ${ }^{151}$ suggest that the transportation of goods was already happening in the Ha C-D period. ${ }^{152}$ This must have been similar to that of the La Tène graphite trade. ${ }^{153}$ In addition to the predominant Moravian graphite deposits, other sources (such as the graphite in the East-Croatian Psunj Mountain) ${ }^{154}$ might also have been used during the Iron Age, at least on the local and regional levels.

A fragment registered under the inventory number 1.26213.583.9. (Fig. 15.11, Sample 27 on Fig. 20.7) belongs to a $\mathrm{C}$ type horn handled mug, which features an everted rim and vertically grooved decoration on its strongly inverted shoulder. Its interior surface is partly burnished and horn-like projections decorate its handle. This mug type is abundant among the Iron Age finds of the Carpathian Basin and primarily appears in Transdanubia, in south-western-Slovakia, and on the Great Hungarian Plain. ${ }^{155}$ Its closest analogy was found at Szob. ${ }^{156}$ Similar mugs have recently been found in Slavonia (Croatia) and in southern part of Transdanubia. ${ }^{157}$ Recently, it has been suggested that this type of mug is of Eastern origin. ${ }^{158}$ That said, this hypothesis is contradicted by the fact that mugs decorated with horn-like projections on their handle mostly resemble those with the strongly inverted shoulders and grooved shoulder decorations characteristic of pottery from the Transdanubian Ha D Period. ${ }^{159}$ Based on the petrographic and LA-ICP-MS analyses of the raw materials, the horn-handled mug resemblesVekerzug type ceramics; therefore it is considered a 'local' product (see Subchapter 2.2.5).

A fragment registered under the inventory number 1.26213.575.10. (Fig. 13.4, Sample 13 on Fig. 21.1) is similar to those Hallstatt type vessels that are decorated with protuberances (e.g. Kóny, Nyergesúffalu, Lábatlan). ${ }^{160}$ Occasionally this protuberance decoration is combined with grooving or burnishing. ${ }^{161}$ Decorating the vessel body with protuberances that were pressed out from the interior of the vessel body is not a rare phenomenon in Slavonia, ${ }^{162}$ in Slovenia, ${ }^{163}$ and in Moravia. ${ }^{164}$ The style often appears on smaller, finely finished vessels and cups. The so-called 'bucchero' variant of this decoration type, typical for the Ha C Period and mostly seen on large biconical vessels (e.g. Sághegy and Boba) ${ }^{165}$ cannot be linked to our find. Based on the petrographic and LA-ICP-MS analyses, the raw material of the vessel with protuberance decoration differs from those of the other examined samples; therefore it can be considered to be import ware at Nagytarcsa. ${ }^{166}$

\subsubsection{Evaluation}

Looking at the Iron Age ceramics of the Carpathian Basin, it can be said that several vessel and decoration types may have been derived from the ceramic repertoire of the local Late Bronze Age cultures. ${ }^{167}$ The development

146 WOLLÁK 1979, 53; JEREM et al. 1984, 167; ROMSAUER 1993, 18; GÁL-MolnÁr 2004, 196; GÁTI 2009, 2014, 134, Pl. 5; JÁKY 2016, 101, P1. 4. 5.

${ }^{147}$ DinNYÉs 2002, Fig. 4.3-4; LANTOS 2011, Fig. 14.1-3.

${ }^{148}$ Kalicz-Koós 1998, 427, Abb. 3.1,3,5.

${ }^{149}$ FREY 1969, 73-77; PATEK 1984,164-166.

${ }^{150}$ KREITER et al. 2014, 138.

${ }^{151}$ GróH 1984, 61, Abb. 6.13-15; GÁti 2009, 66, Fig.

4.12-13.

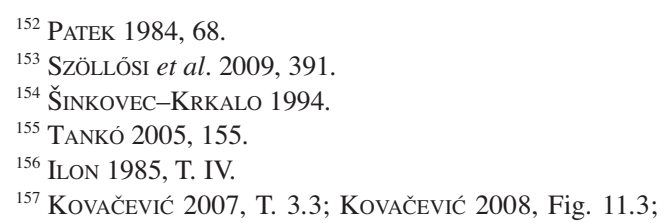
GÁTI 2014, 119-121, Fig. 5; JÁKY 2016, 101, Pl. 4.2.
${ }^{158}$ KEMENCZEI 2007, 52-55.

${ }^{159}$ PATEK 1984, 67, Taf. 19.5-10.

${ }^{160}$ NÉMETH 1996, 370, Abb. 3.2; HoRVÁth et al. 1979, 270, Fig. 22.20, Fig. 39; PATEK 1984, Abb. 17.1; KemenCZei 1977, 78; NÉMETH 1996, 368; JÁKY 2016, 101, Pl. 4. 6,7.

${ }^{161}$ GÁL-Molnár 2004, Taf. 7.3, Taf. 13.4.

${ }^{162}$ KovaČEvić 2008, 65, Fig. 11, T. 2.5-6, T. 5.4-6.

${ }^{163}$ Dular 1982, 71-72, 143-144, Fig. 27, T. 24.226-232; DULAR -KRIŽ 2004, T. 12.5.

${ }^{164}$ Bujna-RomSAUER 1983, Taf. IV.19, Taf. VIII.15.

${ }^{165}$ LÁZÁr 1951, T. XXIII.2-3, T. XXXI.2; LÁZÁR 1955, T.

XXIX.8.

${ }^{166}$ KREITER et al. 2013, 487-488; also see Subchapter 2.2.3-4.

${ }^{167}$ CHOCHOROwsKi 1985, 48-51, Abb. 9; KeMENCZEI 2009, 95. 
of these vessel and decoration types was characterized by transformation and gradual simplification. The formal and stylistic traits (faceting and channelling motives, the dark brown colour of the exterior of the vessels, and the light brown or orange colour of the interior) that are only hidden features in the find assemblage of the Vekerzug Culture simplify this relationship. Nevertheless, the Late Bronze Age pottery traditions which also occur in the archaeological heritage of the Dniester valley ${ }_{1}^{168}$ are most closely related to the Scythian type finds from the Carpathian Basin. These do not posses chronological value but only reflect survival of Late Bronze Age autochthonous populations in the Iron Age. ${ }^{169}$ On some of the Scythian type vessels that were found ${ }^{170}$ in the La Tène ceramic assemblages, Late Bronze Age decorative elements appear more frequently than in the preceding periods. ${ }^{171}$ The examination of the ceramic assemblage of Nagytarcsa is hampered by the fact that more than half of the remains, 154 pieces, are body fragments from hand-formed (barrel-shaped or bowl-shaped) and unidentified vessel types. In light of the settlement finds of this period, it is not an accident that the remaining identifiable finds are dominated by barrel-shaped pots. The thick-walled, more or less profiled bowls with an inverted rim, are not only typical in the Scythian archaeological heritage of the Great Hungarian Plain ${ }^{172}$ but are also commonly found in the open-air settlements of the Hallstatt culture. ${ }^{173}$ This vessel type is also a typical household ceramic of Scythian find assemblages in the Dniester valley. ${ }^{174}$ The barrel-shaped pots were inherited in an almost uniform shape from the La Tène settlements of the Great Hungarian Plain (e.g. Endrőd, Sajópetri and Rákospalota). ${ }^{175}$ Some of the pots were presumably undecorated, although due to the highly fragmented state of the ceramics, the exact ratios cannot be estimated for this site. Several decoration types can be observed in the zone under the rim of the pots: symmetrically arranged, cone-shaped and flat knobs, sectioned knobs, smooth and sectioned elongated knobs, and horizontally arranged ribs with finger impressions. ${ }^{176}$ According to some hypotheses the decoration of the pots is associated with the foods they contained. ${ }^{177}$ The number of the pots with cylindrical necks or everted rims is low in the Nagytarcsa find assemblage. The Late Bronze Age and Pre-Scythian premises of the biconical pots decorated with four knobs under the carination are unambiguously recognizable. The bowls with an inverted rim occur in our find assemblage in different variants. This bowl form was also popular in the Late Bronze Age and in Pre-Scythian times. ${ }^{178}$ Based on the discoid lid found at Nagytarcsa, two lid types of the Vekerzug Culture could be distinguished. Their known occurences have been collected. The wheel-turned cups, jugs, and bowls found amongst the finds directed attention to the problem of the occurrence of wheel-turned vessels in the Carpathian Basin. ${ }^{179}$ Due to the large number of finds of the wheel-turned vessels, archaeologists concluded that on a local level ${ }^{180}$ these vessels were produced in Scythian pottery workshops that specialized in wheel-turned wares. ${ }^{181}$ The petrographic analysis of the Scythian finds of Nagytarcsa showed the same geographical origin of the hand-formed, utilitarian ceramics and of the wheel-turned wares; therefore the wheel-turned vessels can unambiguously be considered local products. A series of petrographic analyses, which included several ceramic types showed that higher quality raw materials were used for the production of technologically more demanding vessels than for household ceramics. At the same time, the obvious differences in colour, wall width, size and body ratios, bottom and handle design, as well as the decoration of the same vessel types underscore the supposed specialisation within pottery manufacturing. The uniform grey colour and the even firing that is typical of most wheel-turned vessels suggest the existence and use of special firing kilns, though no archaeological evidence of such kilns was found at Nagytarcsa or at earlier excavations. ${ }^{182}$

With regards to the ceramic technology, however that most of the samples examined still derive from handformed wares. Wheel-turned products were found at the site. Without question, they should be considered local products. Their low number (they represent $8.55 \%$ of the entire ceramic assemblage) suggests that wheel-turned

${ }^{168}$ SMIRNOVA 1997.

${ }^{169}$ KemenCZei 2000, 47; KemenCZei 2009, 96.

${ }^{170}$ SZABÓ-TANKÓ 2007, 173; SZABÓ et al. 2007, 234-237; SZABÓ 2007b.

${ }^{171}$ MARÁz 1981,100-101.

172 PÁRduCZ 1940, 91; BotTYÁn 1955, 20; CHOCHOROWSKI 1985, 32-34; KEMENCZEI 2009, 97.

${ }^{173}$ STEGMANN-RAJTÁR 1996, 458; JEREM 1986, 107-123;

ĎurkOVIČ 2007, 18; STEGMANN-RAJTÁr 2009, 80.

${ }^{174}$ SMIRNOVA 2001, 67-68.

${ }^{175}$ MENNA 2006; SZABó 2007a; TÉZER 2011.
${ }^{176}$ Chochorowski 1985, 36-39, Abb. 3; Kemenczei 2009 , $96,100$.

177 VERES 2008, 63.

${ }^{178}$ KeMENCZEi 1984, 67; KeMENCZEi 1989.

${ }^{179}$ For a more detailed summary, see: ROMSAUER 1991; Chochorowski 1996; Chochorowski 1998, 481-484; CziFra et al. 2011; KASHUBA et al. 2012

${ }^{180}$ LengYel 1964, 27; DuŠEK 1966, 37; PÁRDUCZ 1973, 326; DUŠEK 1979, 136; MosCALU 1983, 358.

${ }^{181}$ LENGYEL 1964, 27; DUŠEK 1979, 126, 136.

${ }^{182}$ CZIFra et al. 2011, 246-247. 
pottery was less important at this settlement. ${ }^{183}$ With regards to the development of ceramic production technology, the combined production technique plays a more significant role on the site (see details in Subchapter 2.2.1). Specifically, a transitional phase in the development of ceramic production technology was noted since wheel-turning occurs sporadically alongside the combined production technique, which increasingly utilises the wheel. ${ }^{184}$ The discovery of combined production techniques in the Vekerzug pottery tradition has brought a new dimension to the study of early wheel-turned pottery in Eastern Europe. The existence of this "intermediate" phase fits well with the general macro-evolutionary tendency of transmission of the wheel technique, as already observed in the Late Hallstatt/Early La Tène Period. ${ }^{185}$ The next stage in the development of ceramic production technology happens when the hand-building and the combined technique is surpassed by the use of wheel-turning. In view of these results it can be said that ceramic technological and petrographic analyses serve as excellent methodological tools in understanding changes in ceramic production technology. With the help of these scientific methods, the documentation of changes in ceramic production technology can be refined. They may also help refine the chronological classifications for existing sites and clarify ceramic connections amongst more sites. More sophisticated conclusions can be drawn regarding the degree of ceramic manufacturing, as well as the possible specialisation/standardisation of any given vessel type.

The presence of forms and decorations that are foreign to the pottery traditions of the Vekerzug Culture at Nagytarcsa are obviously an influence of the Hallstatt Culture. It was revealed that the raw materials used in some of the Hallstatt type vessels found at Nagytarcsa are identical to those used in local products and that they are the results of identical production processes. In light of this, the presence of itinerant potters that moved between the territories of the Hallstatt Culture and the Scythian settlement cannot be excluded. ${ }^{186}$

\subsection{Chronology}

The lifespan of the Iron Age settlement can primarily be estimated based on the Scythian and Hallstatt type ceramic assemblage recovered from the settlement features. During the Iron Age the endurance over long periods of household ceramic types renders the precise dating of smaller settlements, as well as settlement fragments, more difficult. The vast majority of the ceramic assemblage itself has no dating value. This is true for the biconical pots with inverted rims, an artefact type that is present in the find assemblage as bowls with facetted rims. The unambiguous connection to the Late Bronze Age of the latter bowl type both indicates the continuity of pottery traditions, and the survival of societies that fostered, preserved and in some ways further developed these pottery traditions. ${ }^{187}$ The barrel-shaped pot type - as pointed out earlier - has even more common formal traits, however, this pot type starts to dominate the ceramic assemblages from the Ha D Period. The analogies to the barrel-shaped pots decorated with elongated horizontal knobs or sectioned horizontal knobs, can be placed in a much narrower timeframe. These primarily occur on sites dating to the second part and to the end of the Ha D Period. ${ }^{188}$ Vessels that are unambiguously identified as Hallstatt type wares with prominent, sharp carinations, channelled decoration on the short and vertical shoulder part, as well as graphite lattice patterns both on the interior and on the exterior surfaces of the vessels become common in the Ha D2 Phase of the Hallstatt Culture. ${ }^{189}$ Among the graphitic vessels, the C (Vekerzug) type cup with horn-like handle decoration is one of the primary, characteristic features of the Ha D period. ${ }^{190}$ Later variants of this type of vessel, with protuberance decoration, appear almost in parallel with the above-mentioned mugs. ${ }^{191}$

${ }^{183}$ Similar proportion was observed in case of Nyírparasznya (CZIFRA 2016, 100), and significantly lower ratio $(2,1 \%)$ was documented at Čečejovce/Csécs (SK) (MiroššAYOvÁ 1994, 44). Curiously, the proportion of wheel-turned ceramics at Scythian Period settlements does not even approximate the pottery distribution ratios of the contemporaneous cemeteries where the ratio of wheel-turned pottery ranged around $30 \%$ of the total ceramic assemblage (CHOchorowsKi 1985, 48-49; CHOCHOROWSKI 1996, 116).

${ }^{184}$ KREITER et al. 2013, 487.
185 AUgIER et al. 2013, 565-568; TAPPERT 2015, 175-176.

${ }^{186}$ KREITER et al. 2013, 487-488. See also Subchapter 2.3.

${ }^{187}$ KeMENCZEI 2000, 47.

188 JEREM 1986, T. 3; MirošŠAYOVÁ 1987, 117; MirošŠAYOVÁ 1994, 48; ĎURKOVIČ 2007, 23.

${ }^{189}$ PATEK 1984, 67, Abb. 19.5-10; JÁKY 2016, 101-102.

${ }^{190}$ TANKÓ 2005, 155.

${ }^{191}$ KeMENCZEI 1977, 78; NÉMETH 1996, 368. 
Fortunately, radiocarbon dating could be conducted in Poznań on samples recovered from five animal bones that represent four features (26/26., 551/581., 553/583., 564/774) of the settlement. The calibration was made with OxCal software. The dates produced (Poz-36266-36271) cover the 2460-2490 \pm 30 BP time period (Fig. 19). Only the sample collected from Feature 564/774. reflects a greater interval (2390 $\pm 30 \mathrm{BP})$. The given intervals encompass the true ages of the samples with a probability of ca. $68 \%$ and ca. $95 \%$. The deviation of the ${ }^{14} \mathrm{C}$ dating (or the sample collection/contamination) is marked by the difference between the two measurements conducted on samples from the same feature (26/26.). Based on the relative chronological analysis conducted by the means of traditional typological approach of archaeology and based on the results of the radiocarbon measurements, the settlement at Nagytarcsa can be dated between the middle of the $6^{\text {th }}$ to the turn of the $6^{\text {th }} / 5^{\text {th }}$ century BC.

\subsection{Scythian and Hallstatt relations in the region of the Danube bend}

As a result of complex mutual interactions between the communities of the Carpathian Basin and the forested-steppe and steppe regions beginning in the final phase of the Late Bronze Age, ${ }^{192}$ the territories East of the Danube (the Great Hungarian Plain, Transylvania and the forelands of the Carpathian Mountains) fell under the influence of Scythian cultures from the steppe and the forested-steppe zone. ${ }^{193}$ As a result the cultural unit identified in the archaeological literature as the Vekerzug Culture (or Alföld/Vekerzug group) evolved on the Great Hungarian Plain. Based on the relatively large number of Scythian type artefacts found in the Hallstatt context in Transdanubia some scholars presumed exceptionally strong and expansive Vekerzug influence in the eastern forelands of the Alps. ${ }^{194}$ Partly due to this suggestion, earlier scientific works emphasized the aggressive, military habits of the Vekerzug Culture. Consequently, the confrontation of the agricultural Hallstatt and the nomadic 'Scythian' populations of the Carpathian Basin was assumed. ${ }^{195}$ Material evidence of armed conflict between 'Scythian' and local groups was documented at least at two fortified settlements dating to the end of $7^{\text {th }}$ century B.C.: Smolenice-Molpír (SK) and Dédestapolcsány-Verebce-tető (HU). ${ }^{196}$ However, a more differentiated analysis of the written sources and the archaeological finds point to the peaceful nature of the relationship between the Iron Age populations of the Great Hungarian Plain and Transdanubia, especially from the second half of the $6^{\text {th }}$ century onward. ${ }^{197}$ Based on the large number of Scythian type artefacts occurring on Hallstatt territories this revelation led to the idea that the two groups might have lived together. This led to the assumption that a Hallstatt-Scythian mixed cultural unit existed in southwestern-Slovakia, ${ }^{198}$ in the north-western ${ }^{199}$ and in south-eastern ${ }^{200}$ parts of Transdanubia. Settlements and cemeteries with mixed assemblages in the greater Danube Bend region ${ }^{201}$ emphasize this suggestion and provide an argument for a gradual acculturation process in the south-western part of present-day Slovakia.

A relatively large number of Vekerzug sites have been found recently. On them, ceramics and metal artefacts with a Hallstatt character occurred alongside the local products and wares. ${ }^{202}$ Compared to its significant western orientation, this phenomenon reflects a partly contemporary, but reverse interaction of the Vekerzug Culture. The ceramic assemblage of Nagytarcsa-Urasági-dülö sheds light on deeper aspects of these peaceful and good neighbourly relations. At present, however the character and the complexity of this relationship is hard to assess. The petrographic characteristics of the so-called 'foreign' vessels in Nagytarcsa identify the place where these vessels were manufactured as the Danube Bend region. This confirms the suggestion that the most important scene of Scythian and Hallstatt interaction may well have been the region of the Danube Bend ${ }^{203}$ and south-western

\footnotetext{
${ }^{192}$ MetZNER-NebeLsick 2010, 142-143.

${ }^{193}$ Chochorowski 1998, 487-489; KemencZei 2003, 179; KemencZei 2009, 16-17. 1998,520

${ }^{194}$ FoLTinY 1963, 30-31; VÉKONY 1986, 263; TERŽAN

${ }^{195}$ Kromer 1987, 43-63; KRISTIANSEN 1998, 282-288.

${ }^{196}$ PARZinger-STEGManN-RAJTÁR 1988; HeLlmuth 2006; Hellmuth 2007; V. SZABó et al. 2014.

${ }^{197}$ PÁrducz 1965b; Harmatta 1968; KemencZei 1977, 67; JeRem 1981, 114; KemenCZei 2009, 28; KemenCZei 2010, 121122; HORVÁTH 2015.
}

21.

${ }^{198}$ PARZINGER-STEgmanN-RAJTÁr 1988; RoMSAUER 1993,

${ }^{199}$ GÁL-MOLNÁR 2004, 184; MOLNÁR 2007, 64.

${ }^{200}$ SZABÓ-FEKETE 2011.

${ }^{201}$ Evidence for such interactions are documented on both sides of the River Danube: e.g. at Modrany/Madar (SK), at Nové Zámky/Érsekújvár (SK), at Pomáz (HU) and at Szob (HU) (DušEK 1976; StegmanN-RAJTÁR 2009; KemenCZei 1977; ILON 1985).

${ }^{202}$ KemencZei 2009, 10.

${ }^{203}$ KemencZei 1977, 67. 
Slovakia. ${ }^{204}$ In comparison, the influence of the eastern-Slovakian populations which entertained close relations with the Danubian Hallstatt territories, ${ }^{205}$ must have been significantly lower.

\section{ACKNOWLEDGEMENTS}

I am grateful to Orsolya Mészáros for ceding the right of publishing the Iron Age finds of Nagytarcsa. The line drawings of the artefacts were prepared by Ágnes Kazsóki, whilst Márta Lakó, Lóránt Peuser, and Nicklas Larsson provided assistance in digitalising; their work is greatly appreciated.

\section{PETROGRAPHIC, LA-ICP-MS, AND XRD ANALYSES OF VEKERZUG AND HALLSTATT TYPE CERAMICS FROM NAGYTARCSA-URASÁGI-DÜLŐ ARCHAEOLOGICAL SITE - A SUMMARY ${ }^{206}$ (ATTILA KREITER, ÉVA KOVÁCS-SZÉLES, MÁRIA TÓTH, ORSOLYA VIKTORIK)}

\subsection{Introduction}

In this study, 44 ceramic sherds were selected for petrographic analysis from the Early Iron Age ceramic assemblage of Nagytarcsa. The samples represent the most common Vekerzug vessel types such as jars (4 pcs), bowls (15 pcs), cups ( 2 pcs), mugs (5 pcs), biconical pots (12 pcs) and squat-shaped pots (6 pcs). Of these, eight samples including jars ( 2 pcs), biconical pots ( 2 pcs), mugs ( 3 pcs) and a bowl with an inverted rim (1 pc) are considered to have been thrown on a fast wheel, while two mugs were made with a combined technique using wheel fashioning in the final stages of production (slow wheeled). The other samples were hand-formed. In addition to Vekerzug types, seven Hallstatt type vessels were also selected for petrographic analysis. The raw materials of five, presumably imported (Hallstatt) and three local (Vekerzug) ceramic vessels were also compared using Laser Ablation Inductively Coupled Plasma Mass Spectrometry (LA-ICP-MS) and X-ray powder diffraction spectroscopy (XRD) in order to assess the provenance of 'foreign' ceramic types and possible differences in firing temperatures. Particular attention was given to the comparison of the technological features of hand-formed and wheel-turned ceramic types in order to assess the possibility of on-site presence of pottery workshops specialized in the manufacturing of wheel-turned wares.

\subsubsection{Thin section analysis}

Thin section analysis was used to examine possible similarities and differences between raw materials, fabric preparations, and tempering practices between wheel-made and hand-formed vessels. ${ }^{207}$ Though different interpretations of our preliminary results were published earlier, ${ }^{208}$ detailed analysis of the data sheds further light on potters' traditions at an Iron Age site. By means of petrographic analysis five fabric groups could be distinguished based on their most characteristic non-plastic inclusions.

Fabric 1 (Fig. 20) is represented by jars $(1,9)$, bowls $(2,4,6,7,34,41)$, cups $(25,27)$, mugs $(18,28,39$, $44)$, and biconical amphorae $(12,35)$. The main characteristic of this group is that these vessels were not tempered; the very fine $(<0.1 \mathrm{~mm})$ raw materials probably occurred naturally. The exterior surfaces of a bowl (4) and a cup (27) display high gloss burnishing (graphite?). These vessels are Hallstatt types. Petrographic analysis, however, revealed that these vessels have similar non-plastic inclusions compared to other vessels in this group in terms of their type, size, roundness and amount. The main non-plastic inclusions of the vessels are monocrystalline quartz and small amounts of muscovite mica.

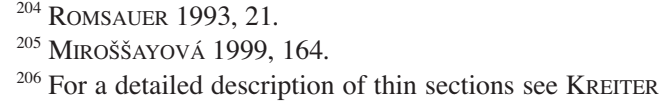

\footnotetext{
${ }^{207}$ During the petrographic analysis inclusion density, size categories, inclusion sorting and roundness of inclusions were identified based on the guidelines of the Prehistoric Ceramic Research Group (PCRG 2010)

${ }^{208}$ CZIFra et al. 2011; Kreiter et al. 2013.
} 


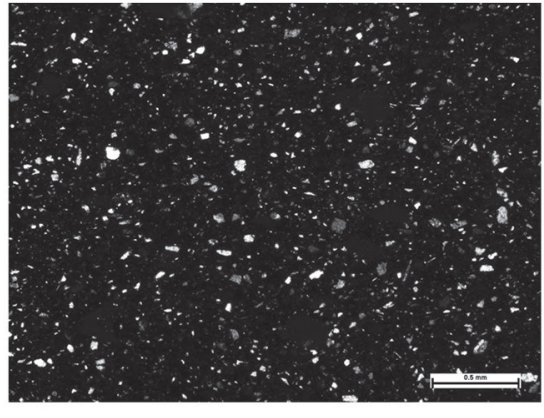

Sample 9

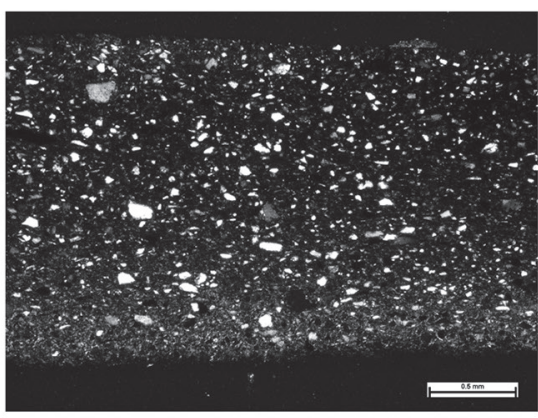

Sample 41

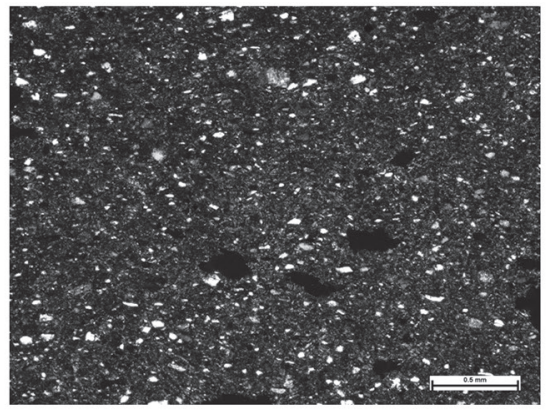

Sample 2

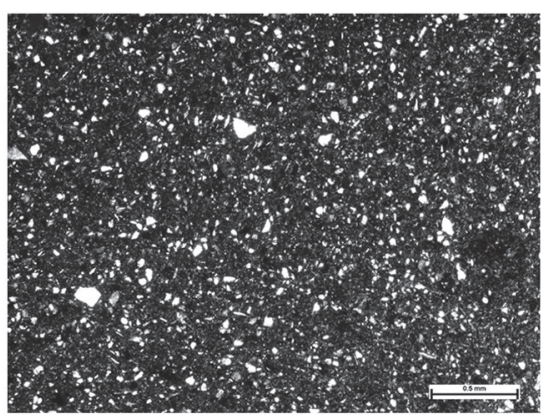

Sample 27

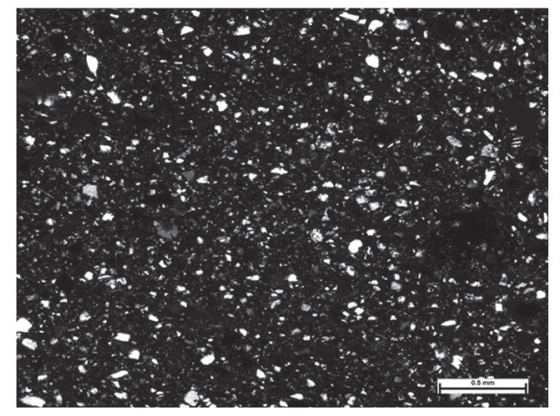

Sample 34

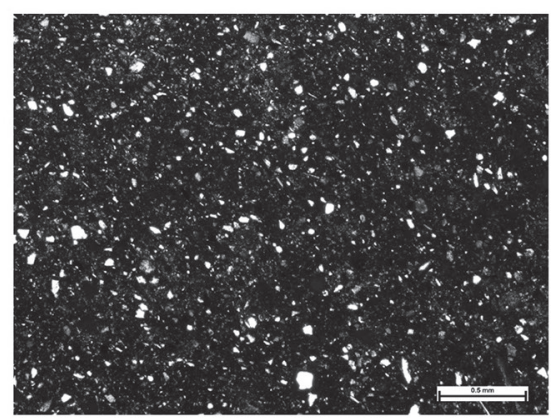

Sample 44

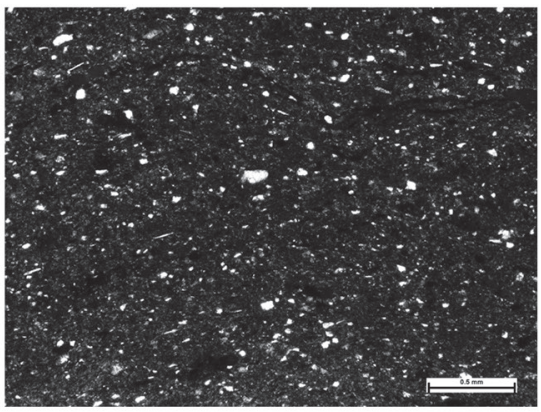

Sample 4

6

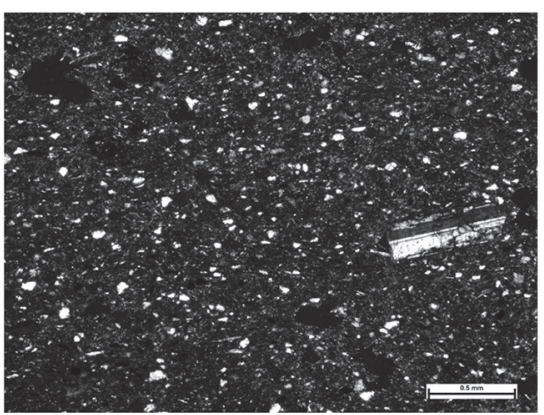

Sample 35

Fig. 20. Characteristic very fine-grained vessels from Fabric group 1 (All microphotographs are XPL) 
Fabric 2 (Fig. 21) can be divided into two subgroups. Fabric 2a is represented by a Hallstatt type bowl (13) and a cup (25). Fabric $2 b$ consists of a Vekerzug mug (26). In general, Fabric 2 is characterized by fine (0.1$0.25 \mathrm{~mm}$ ), mainly monocrystalline, quartz inclusions. Thus, the vessels in this fabric show slightly larger inclusions than in the previous one. The raw materials of the vessels were probably tempered with sand. The bowl and the cup in Fabric 2a are Hallstatt vessels, and within the traditional typological approach they are considered imports; their composition is very similar petrographically. They also show similarities to a Vekerzug mug (26) in terms of the type and size of inclusions. It must be noted that the two Hallstatt vessels are more similar to each other petrographically than to the mug, since the grain size distribution of the Hallstatt vessels is more even.

Fabric 3 (Fig. 22.) comprises one Vekerzug type bowl (5), barrel-shaped Vekerzug type pots (15, 19, 29, 32, 33) and one Hallstatt type biconical pot (38). The ceramics were either tempered with different size ranges of rock fragments (fine to coarse-grained: $0,1-3 \mathrm{~mm}$ ), or sand containing those rock fragments. The composition of

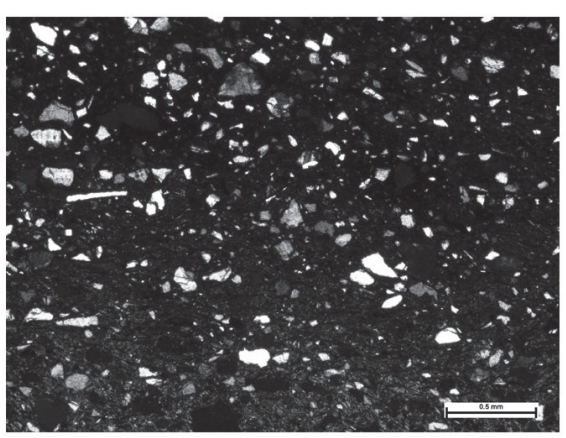

Sample 13

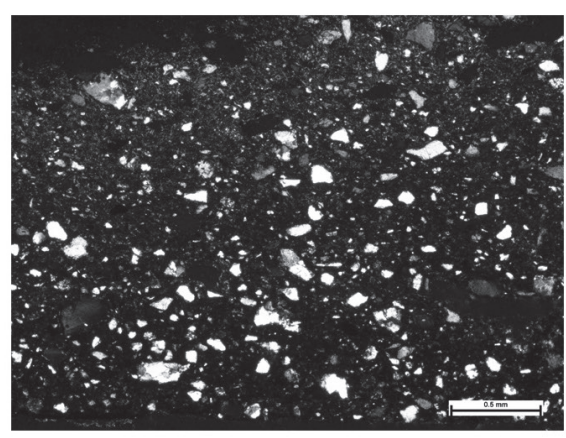

Sample 25

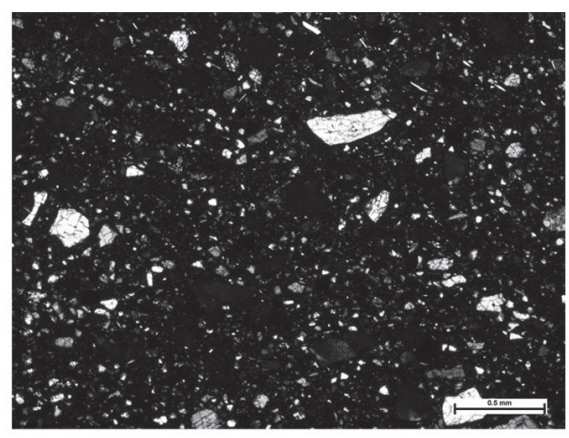

Sample 26

Fig. 21. Fine-grained vessels from Fabric group 2 (All microphotographs are XPL) 
ceramics is different from Fabrics 1 and 2. Furthermore, significant diversity can be observed within the group as well, therefore Fabric 3 can be divided into subgroups. The amount of volcanic rock fragments, mostly plagioclase feldspar and andesite, is significantly higher than in other fabric groups. The compositional variability within this group needs to be emphasized because it may reflect different raw material sources.

Fabric 4 (Fig. 23) is represented by biconical pots (3, 23-24), a biconical jar (8), bowls (10, 14, 20, 21, $22,36)$ and flowerpot-shaped pots $(11,16,17,30,31,40,43)$. On the exterior of a biconical pot (3) and a biconical jar (8) high gloss burnishing (graphite?) is also present. The vessels were tempered with different size ranges of sand (fine to medium: $0.1-1 \mathrm{~m}$ ). The sizes of non-plastic inclusions are smaller and fewer volcanic fragments are present than in Fabric 3. Calcareous inclusions also appear. Two pots (17, 40) and a bowl (21) were also tempered with grog. It should be noted that in sample 17 there is even a $1 \mathrm{~cm}$ large grog fragment with a burnished surface. The fabric, composition, and grain size distribution of grog fragments are similar to those of the raw material to

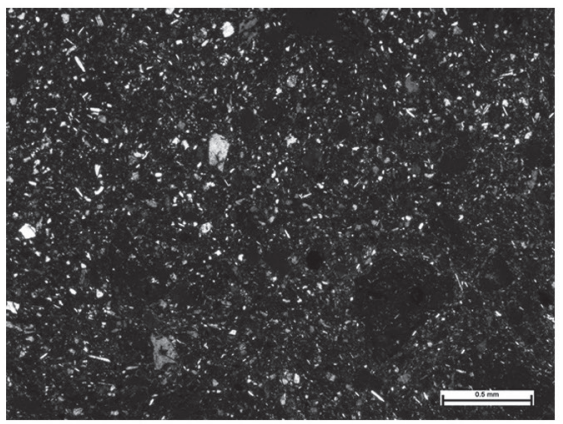

Sample 15

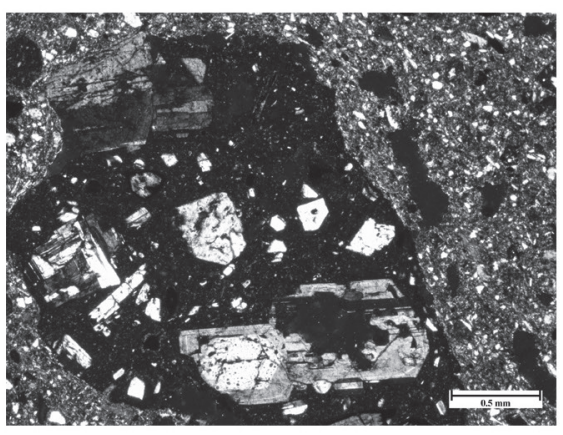

Sample 29

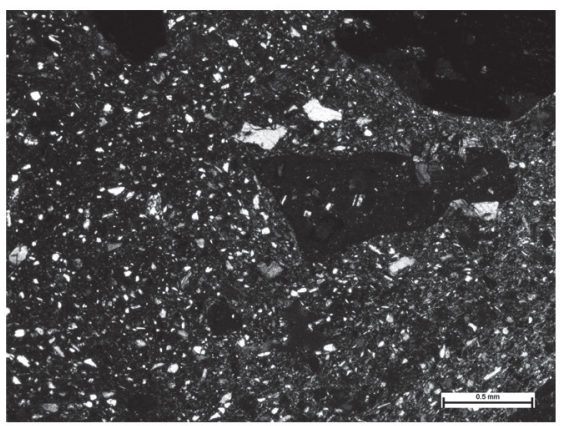

Sample 33

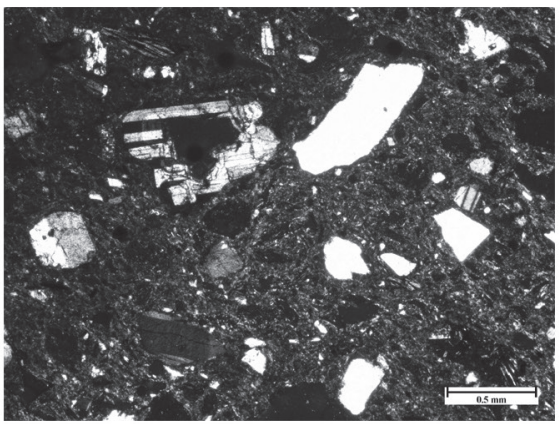

Sample 19 2

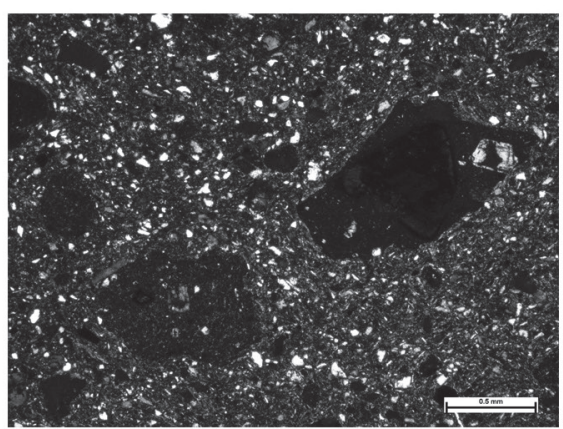

Sample 32 4

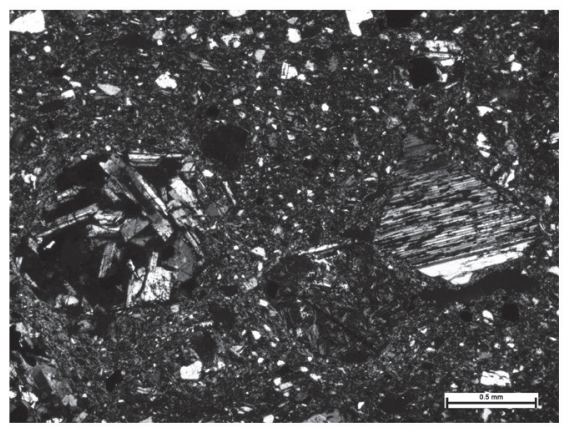

Sample 38

Fig. 22. Medium to coarse-grained vessels from Fabric group 3 (All microphotographs are XPL) 


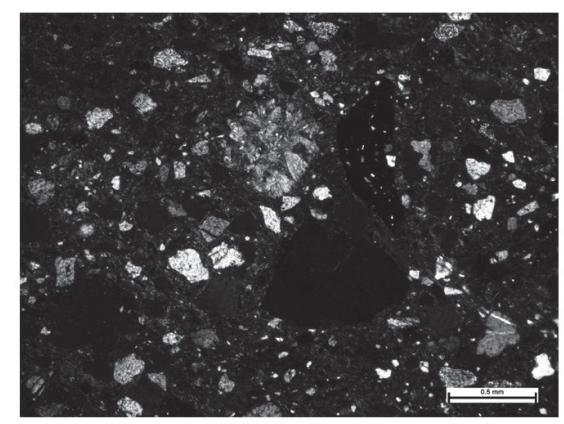

Sample 3

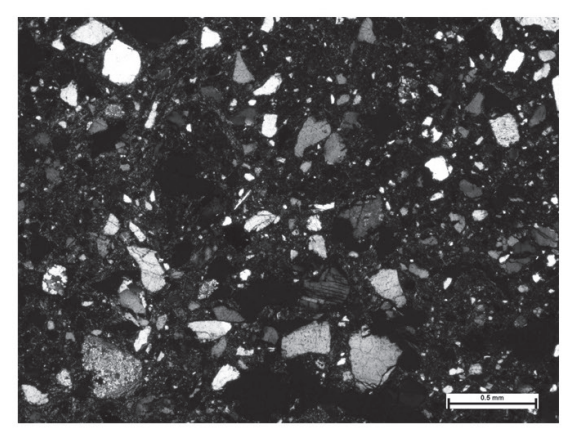

Sample 10

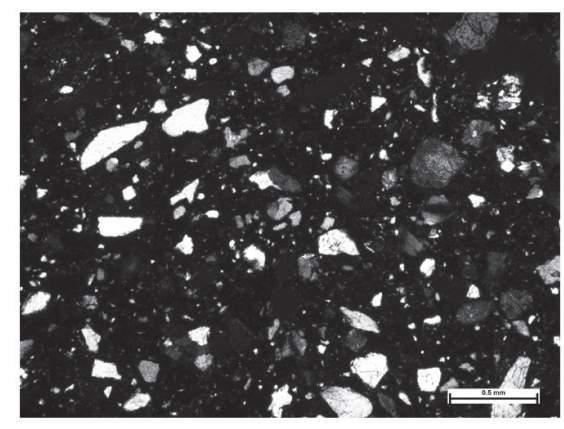

Sample 43

\section{3}

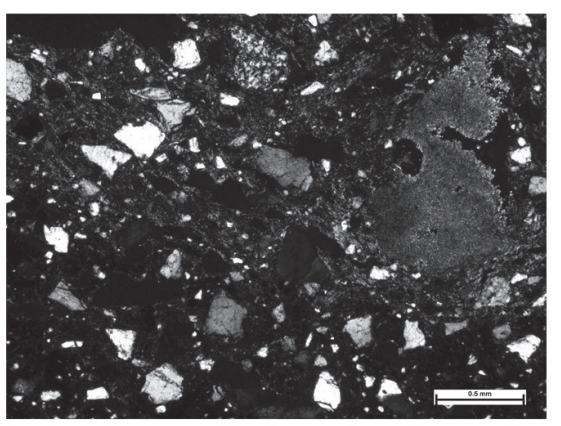

Sample 8

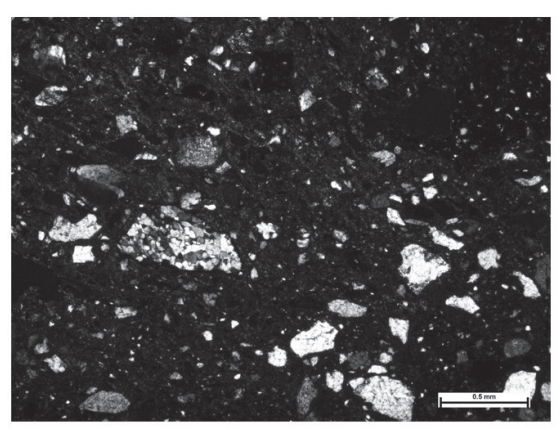

Sample 14

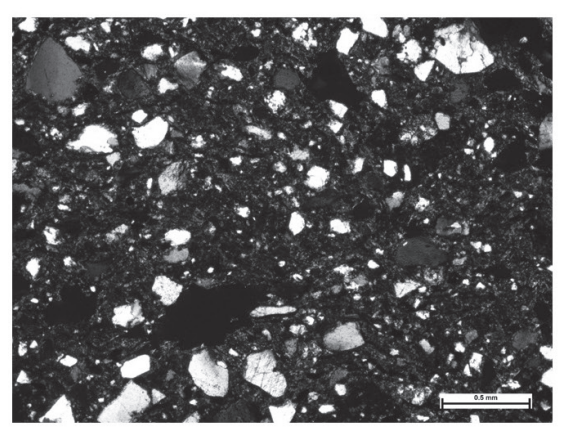

Sample 11

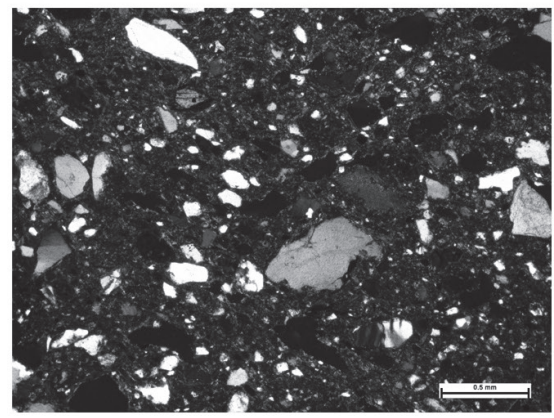

Sample 23

8

Fig. 23. Fine to medium-grained vessels from Fabric group 4 (All microphotographs are XPL) 
which grog was added. Thus, ceramics that were later crushed and used for tempering were manufactured from similar raw materials as the ones in which grog was incorporated. ${ }^{209}$

Fabric 5 (Fig. 24) is represented by a high gloss burnished (graphite?) bowl (37) and a biconical pot (42). The ceramics were made from a 'clean' raw material, which contained sparse amounts of mainly very fine nonplastic inclusions.

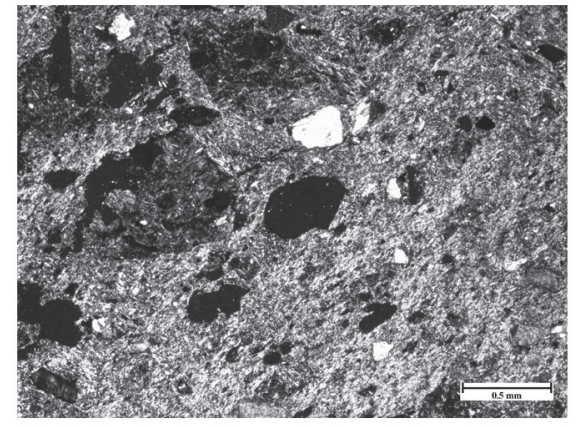

Sample 37

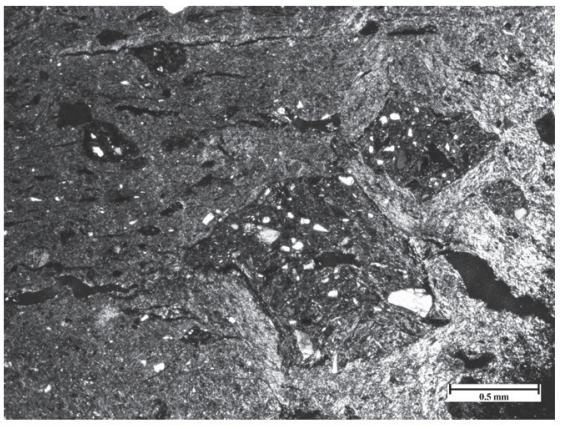

Sample 42

Fig. 24. Very fine-grained vessels with 'clean' raw material in Fabric group 5 (All microphotographs are XPL)

\subsubsection{Observations on manufacturing techniques}

Wares made on a fast wheel found in the assemblage may indicate specialization in ceramic production. Moreover, observations on manufacturing techniques provide a comparative basis to examine possible similarities and differences between Vekerzug and Hallstatt type ceramics (see Subchapter 1.4.10). With regard to technological features the combination of slab building and wheel-fashioning techniques appear in addition to wheel-turning and hand building (most probably slab building) techniques in several instances. In the case of combined manufacturing techniques, conjoining slabs are visible in the cross-section of the ceramics. Thus, these vessels were made from slabs and the products were refined on a slow wheel.

The Hallstatt type bowls $(4,41)$ and the mug $(27)$ in Fabric 1 were hand-built. The degree of orientation of non-plastic inclusions in ceramics, prepared with the combined technique, is similar to those that were identified as wheel-turned. This phenomenon can be interpreted in two different ways: 1. Wheel-turned ceramics were not thoroughly wheel-turned, so a high degree of orientation of the inclusions could not develop. 2. Even though joints of individual building units were not observed on the ceramics identified as wheel-turned - either because the slabs were perfectly joined, or because joint parts do not presently form part of the examined fragments - they may have been hand-built and were almost perfectly refined and finished on a slow wheel.

To sum up the observations on manufacturing techniques, the wheel-turning technique is common for the finest ceramics, which are characterized by very fine raw materials (especially Fabric 1). The combination of hand forming and wheel fashioning is also typical for the finest ceramics. Nevertheless, vessels exclusively manufactured with the hand forming technique also appear amongst the finest ceramics, which are usually Hallstatt types. Exclusively wheel-turned vessels do not seem to be made from sandier raw materials (e.g. Fabric 2), but the combination of hand forming and slow wheel technique does appear on one cup (26).

According to the archaeological data, both hand-formed and wheel-turned variants of the cups, jugs, biconical pots, and bowls occur at Scythian sites located on the Great Hungarian Plain. In the case of cups and jugs, their wheel-turned versions dominate the assemblage while their hand-formed variants are rare. Similar technological shifts are also very likely to have happened with other vessel types (except squat-shaped pots), although suitable data is still lacking to confirm this suggestion. In the case of the examined samples, it was not only cups and jugs that were made from different raw materials, perhaps by different potters, but changes in manufacturing

${ }^{209}$ KreITER 2007a; KreITER 2007b; KREITER 2009. 
techniques can also be found. There seems to have been a transitional phase between the hand-formed and wheelturned vessel variants since besides hand-formed $(8,20,44)$ and wheel-turned $(9,18)$ vessel variants a combined technique $(1,9,26,28,39)$ was also observed.

In the case of bowls, their hand-formed variants $(2,4,5,6,7,10,13,14,21,22,36,37,41)$ dominate the examined sample assemblage, while there is only one example of a wheel-turned vessel (34). These results correspond with the macroscopic examination of other bowls from this site. The petrographically examined barrel-shaped pots $(11,15,19,23-24,29,30-33,40,43)$ were formed by hand and made locally from somewhat coarser raw materials than the other vessel types.

The Hallstatt type ceramics examined here deserve particular attention. They were all hand-formed, much like the hand-formed Vekerzug type ceramics. Thus, the manufacturing technique of Hallstatt type ceramics corresponds with local traditions.

\subsubsection{Geological background}

Nagytarcsa lies on the alluvial fan of the River Danube (Pest Plain), which is characterised by interfluves, higher terraces, erosion and derasion valleys (Fig. 25). Typical geomorphological forms found on its territory
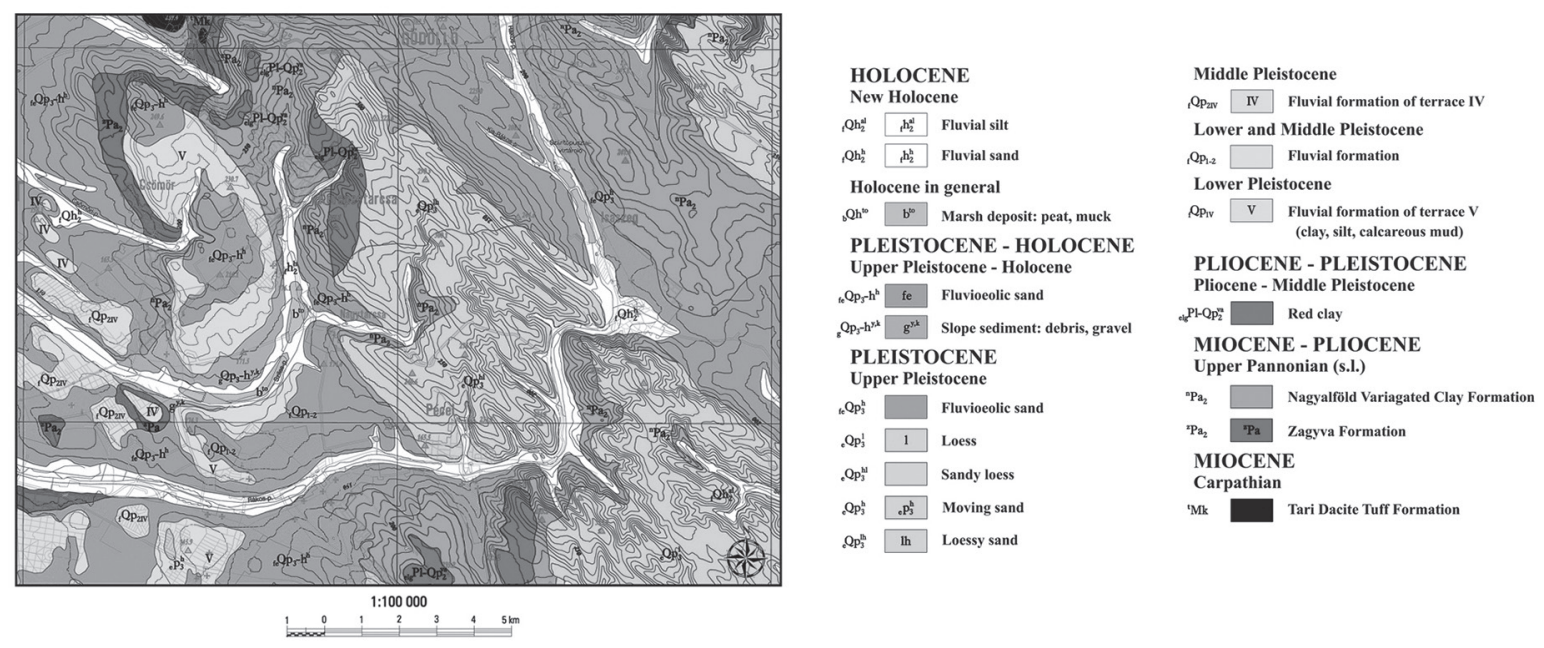

Fig. 25. Geological map of Nagytarcsa and its surroundings (after GYALOG 2005)

evolved due to fluvial and derasion processes. ${ }^{210}$ The geology of the territory has been influenced by the geomorphic processes of the Danube since the very beginning of the Pleistocene $(\sim 2.4 \mathrm{Ma})$. At that time, the Danube flowed towards the Great Hungarian Plain, across the Visegrád Pass, between the Börzsöny and Visegrád Mountains. At the settlement of Vác, the river turned southeast and most probably united with the paleo-Tisza River near the settlement of Szentes. It settled in its current bed due to the depression of the Kalocsa-Baja-Zombor area. ${ }^{211}$ The landscape around Nagytarcsa is formed today by the Szilas Creek that runs into the River Danube.

The formations of the Upper Pannonian Period ( 8.9-2.4 Ma) are present both on the surface and below surface of this hilly area. At that time, the bay of the Pannonian Lake, which was broken up by various islands, straits and peninsulas, was filled up with traction and suspended load transported by rivers flowing into the lake, mostly from the north-west and partly from the north-east. The rivers that filled up the gradually shrinking Pannonian Lake accumulated their loads previously as a fluvial-lacustrine hydrological network. On the surface geographical map of the territory ${ }^{212}$ the Upper Pannonian fluvial and the lacustrine Zagyva Formation $\left({ }^{2} \mathrm{~Pa}_{2}\right)$ can easily

\footnotetext{
${ }^{210}$ MAROSI-SOMOGYI 1990.

${ }^{211}$ BORSY 1989.
}

${ }^{212}$ Gyalog 2005; SchareK et al. 2005. 
be seen. This geological formation is loose, contains charred plant debris, and consists of dense layers of mediumand fine-grained sand, sandstone, silt, clay and clay marl layers. Earthy and woody lignite layers also frequently occur in the formation. ${ }^{213}$ Often 10-20 m thick sandstone intercalations (channel floor, point bar, flood sediments) and palaeosoil layers described as 'variegated clay' occur in the geological sequence. This is followed in the sequence by the Upper Pannonian Nagyalföld Variegated Clay Formation $\left({ }^{n} \mathrm{~Pa}_{2}\right)$, which is a typical lacustrine-fluvial sediment. It consists of variations of bluish-grey sand and grey, yellowish-grey clay layers with reddish-brown flecks. These layers appear in varying thicknesses. Sand layers with lignite and pebble often occur in the geographical sequences, too. ${ }^{214}$

The Pleistocene $(2,4 \mathrm{Ma}-10 \mathrm{ky})$ is characterised by sediments that evolved in relation to climate changes (glacials and interglacials), by repetitive crustal movements and by the geomorphological results of these processes. The inner part of the Carpathian Basin was a periglacial territory during the glacial periods of the Pleistocene; therefore it was characterised by a continental steppe climate with short summers, cold and dry winters, loess formation, fluvial accumulation, and ice plucking. During the warming interglacials between the glacial periods, or during the ice-free interstadials within a glacial period, the climate was predominated by warm summers and mild winters. Soils evolved during these periods on loess territories. Today's hydrological network was formed during the Pleistocene. ${ }^{215}$ The Pliocene-Middle Pleistocene red clay $\left({ }_{\mathrm{elg}} \mathrm{Pl}-\mathrm{Qp}_{2}{ }^{\mathrm{va}}\right)$ is the autochthonous weathered sediment of hill top areas. It also occurs in a moderately redistributed form, which is a result of down-slope mass movements. ${ }^{216} \mathrm{The}$ Lower and Middle Pleistocene fluvial sediments $\left(\mathrm{Qp}_{\mathrm{f}-2}\right)$ are represented by clay, silt and calcareous mud. The Middle Pleistocene fluvial sediment $\left({ }_{\mathrm{f}} \mathrm{Qp}_{2 \mathrm{IV}}\right)$ is formed by pebble and sand sediments of the Nos. IV-V terrace of the Danube's alluvial fan. These are often covered by travertine layers. By the beginning of the Upper Pleistocene the geomorphology of the hilly area around Nagytarcsa had evolved. One of the most typical sediments of the Upper Pleistocene is loess: fluvioeolic sand $\left({ }_{\mathrm{fe}} \mathrm{Qp}_{3}{ }^{\mathrm{h}}\right)$, sandy loess $\left({ }_{\mathrm{e}} \mathrm{Qp}_{3}{ }^{\mathrm{hl}}\right)$, loessy sand $\left(\mathrm{Qp}_{3}{ }^{\text {lh }}\right)$. The other is the blown sand $\left(\mathrm{Qp}_{3}{ }^{\mathrm{h}}\right)$, which is an aeolian redistributed deposit. The colluvial sediment type, which is occasionally mixed with pebble deposits $\left(\mathrm{g}_{\mathrm{g}}-\mathrm{h}^{\mathrm{y}, \mathrm{k}}\right)$, is primarily redistributed by gravitational processes such as areal erosion and gravity mass movements.

The specific deposit of the Holocene (10 ky - today) is peat $\left(\mathrm{Qh}^{\text {to }}\right)$, which is formed by the death and partial anaerobic break down of biomass generated by the eutrophisation processes on the bottom of shallow lakes and widening creek beds. The new Holocene fluvial silt and sand $\left(\mathrm{Qhh}_{2}{ }^{\mathrm{h}}, \mathrm{Q}_{\mathrm{Q}} \mathrm{Qh}_{2}{ }^{\mathrm{al}}\right)$ can be traced to the low flood-plain formations of the Danube's alluvial sediments. Their raw material is mainly fine-grained, while coarser sediments seldom occur.

\subsubsection{Examination of the sediments of the site $e^{217}$}

Ten sediments within the site were analysed in thin sections (sample numbers of the sediments: 17., 13., 12., 10., 23., 16., 19., 18., NTB1, 03/02). The composition of these sediments was compared with that of the ceramics to identify possible ceramic raw material sources. The majority of the analysed sediments are calcareous. Since only a few ceramics contain calcareous inclusions, and it only appears in rare and sparse amounts, calcareous sediments can be excluded as potential raw materials for the analysed ceramics. Altogether four of the analysed sediments show partial resemblance to ceramic Fabric 4, in which there are Vekerzug type ceramics. ${ }^{218}$ With regard to the type and size of inclusions, sediments Nos 16 (formation No. 2., in the depth of 30-70 cm measured from the modern surface ), 17 (formation No. 3., in the depth of 70-105 cm measured from the modern surface), 18 (formation No. 4., in the depth of 105-140 cm measured from the modern surface) and NTB1 (occurred beneath the humus layer) show a resemblance to ceramic Fabric 4. Both the sediments and ceramics are characterised by very fine to medium monocrystalline quartz, but muscovite, polycrystalline quartz, feldspars, chert, and brown amphibole appear as well. Sediments Nos 17 and 18 contain sparse amounts of calcareous inclusions, which were observed in some of the ceramics as well (ceramic samples $10,14,16,17,21,23,30,31,36)$. At the same time, similarly to

\footnotetext{
${ }^{213}$ CSÁSZÁr 1997.

${ }^{214}$ CSÁSZÁr 1997

215 SCHWEITZER 1997.

${ }^{216}$ GYALOG 2005
} 2008 
some of the ceramics in Fabric $4(3,8,11,20,22,24,40,43)$, sediment NTB1 does not contain any calcareous inclusions. Thus, most of the inclusions in the ceramics and the above-mentioned sediments are similar. There are occasional chert inclusions in the sediments and ceramics, but rare neutral volcanic rock fragments in Fabric 4 and late magmatic opal fragments in two ceramics $(16,22)$ do not appear in the analysed sediments. Furthermore, a fundamental difference is that the amount of non-plastic inclusions in the sediments is significantly higher (abundant) than what was observed in the ceramics. Sediments are mainly composed of sand and silt, their clay content is low. For example, Sample 16 is a clayey aleurite sand, or sandy loam, which is mostly composed of sand and silt fractions. Its carbonate content is $4.65 \%$; its clay content is $4 \%$. Sample 17 is a clayey aleurite sand, or sandy loam, which is mostly composed of sand and silt fractions. Its carbonate content is $4.3 \%$; its clay content is $3 \%$. Sample 18 is also a clayey aleurite sand, or sandy loam, which is mostly composed of sand and silt fractions. Its carbonate content is $3.33 \%$; its clay content is $3 \%$. Sample NTB1 is a sandy clay, which contains carbonates. It contains $8 \%$ clay, $10 \%$ loam, $82 \%$ sand. Assessing the sediments from the point of view of ceramic manufacturing, it must be noted that they contain too many non-plastic inclusions and their clay content is low; therefore they cannot be used for ceramic production in their natural state. As a result, the potential raw materials for ceramic production could not be identified although the analyses of raw materials underline the local origin of the analysed ceramics. The compositional similarity of sediments and ceramics imply that these sandy sediments with their low clay content may have been used for tempering more plastic clays types with significantly fewer non-plastic inclusions.

\subsubsection{Results of the LA-ICP-MS and XRD examinations ${ }^{219}$}

The petrographic analysis was complemented with laser ablation inductively coupled plasma mass spectrometry (LA-ICP-MS) to compare the major and trace element composition of Vekerzug and Hallstatt type ceramics. ${ }^{220}$ Samples were also analyzed from digested solutions using ICP-MS technique. ${ }^{221}$ With respect to the results of the petrographic analysis, eight samples were selected for LA-ICP-MS. One biconical pot or bowl-shaped vessel (35), one bowl with an inverted rim (37), and one decorated barrel-shaped pot were chosen from the Vekerzug type ceramics. These were compared with the following Hallstatt type ceramics: jug (8) burnished with graphite (?), mug (27) burnished with graphite (?), bowl (41) burnished with graphite (?), biconical pot (38) burnished with graphite (?), and a bowl (13).

Based on the results of LA-ICP-MS, as well as on the element correlations achieved through the solutionbased ICP-MS analyses, three compositional groups could be distinguished (Fig. 26). The first group is represented by a Hallstatt bowl with embossed decoration (Sample 13) and also by a Hallstatt high gloss burnished (graphite?) biconical pot (Sample 38). The second compositional group is represented by a Vekerzug high gloss burnished (graphite?) biconical jar (Sample 8), a Hallstatt high gloss burnished (graphite?) cup (Sample 27), a Vekerzug high gloss burnished (graphite?) bowl (Sample 37), and a Vekerzug squat-shaped pot (Sample 43). The third group contains a Vekerzug pot (Sample 35) and a Hallstatt high gloss burnished (graphite?) bowl (Sample 41). The composition of the Vekerzug vessels display extensive similarities with some of the Hallstatt vessels in the second and third

${ }^{219}$ LA-ICP-MS analysis was performed by Éva KovácsSzéles, head of the Nuclear Security Department, Hungarian Academy of Sciences, Centre for Energy Research. XRD analysis was carried out by Mária Tóth, research fellow of the Institute for Geological and Geochemical Research, Hungarian Academy of Sciences, Research Centre for Astronomy and Earth Sciences.

${ }^{220}$ LA-ICP-MS analysis was carried out on a Thermo Electron Corp., Finnigan, Elemet2 (Bremen, Germany) type ICP-MS system equipped with a UP 213 A/F type (New Wave Inc., Freemont, USA) laser ablation sample introduction system. A line scan for the measurements was used applying a very low scan speed (50 $\mu \mathrm{m} \mathrm{s}-1)$ in order to improve the resolution of the elemental distribution. Other laser ablation parameters were: repetition rate: $10 \mathrm{~Hz}$, laser beam diameter: $95 \mu \mathrm{m}$, laser beam energy: $70 \%(0.244 \mathrm{~mJ})$. For the laser abla- tion ICP-MS measurements a medium resolution $(R=4000)$ was employed, optimization and mass calibration of the instrument were performed daily by the analysis of NIST 612 glass reference material (NIST, Gaithersburg, USA).

${ }^{221}$ Solution based (destructive) elemental analysis is generally more precise than the laser ablation technique because of the more accurate calibration methods (possibility for matrix matching and homogeneity of the samples). The samples were digested in a distilled concentric nitric acid and hafnium mixture using a microwave digestion system (MARS5, CEM Corp., USA), diluted with deionized water (Milli-Q System, Millipore, USA) and measured by an ICP-MS system. The results of ICP-MS measurements and the correlation of the elements have already been published elsewhere (see CZIFra et al. 2011, Fig. 10a-e; Kreiter et al. 2013, Fig. 7a-e). 
groups, while the Hallstatt samples in the first group are clearly separated. The element profiles show an almost uniform value suggesting a similar provenance and similar raw materials of the Hallstatt and Vekerzug ceramics. Minor compositional differences within the Hallstatt type samples may reflect slightly different clay sources, and suggest different areas of provenance. The higher silver value in samples 8 and 27 could be associated with silver content of the Moravian graphite deposits.
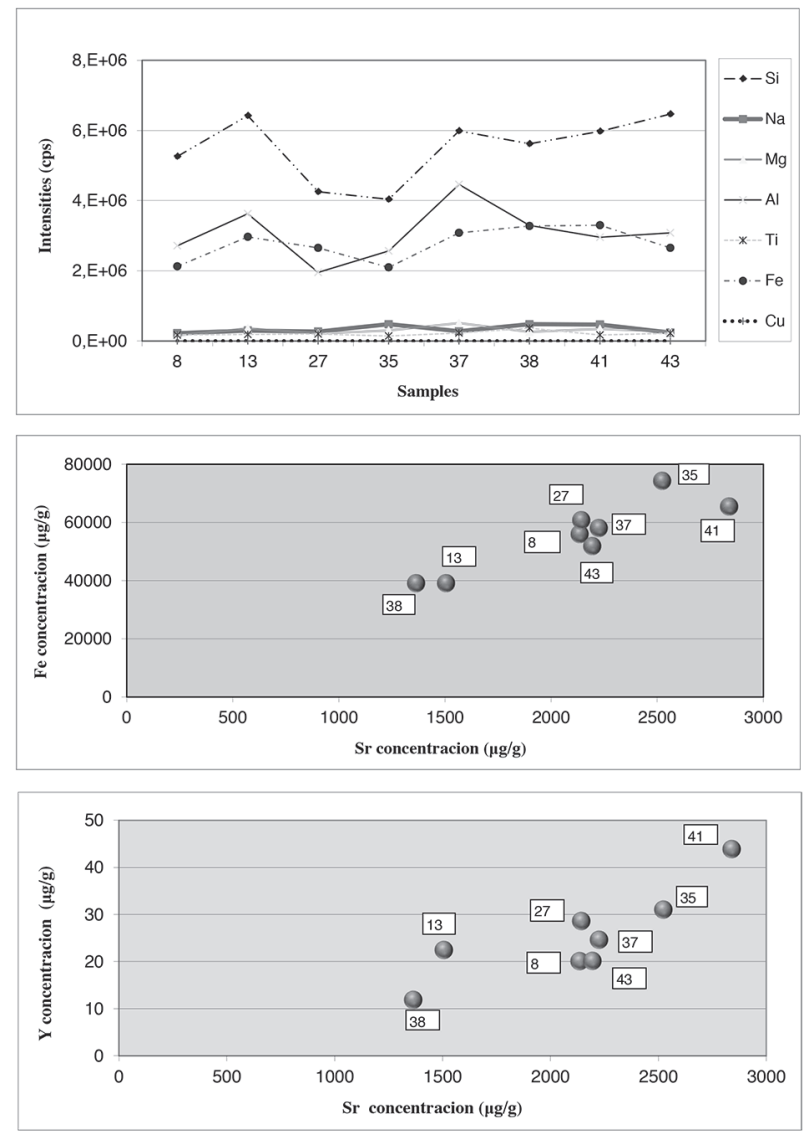

Fig. 26. Results of ICP-MS measurements.

1: Elemental ratios in the case of some major elements by LA-ICP-MS; 2: Fe-Sr elemental correlation from solution based ICP-MS concentration measurements; 3: Y-Sr elemental correlation from solution based ICP-MS concentration measurements

In order to further refine possible technological similarities or differences between hand-formed and wheel-turned vessels, moreover between Hallstatt and Vekerzug type ceramics, the firing temperatures of the ceramics were also analyzed by X-ray powder diffraction (XRD). According to XRD, the firing temperatures of the Hallstatt and Vekerzug type ceramics show similarities. Firing temperatures of the Vekerzug ceramics: biconical pot or bowl-shaped vessel (35): $<800{ }^{\circ} \mathrm{C}$; bowl (37): $800-900{ }^{\circ} \mathrm{C}$; flowerpot-shaped pot (43): $<650{ }^{\circ} \mathrm{C}$. Firing temperatures of the Hallstatt type ceramics: graphite-burnished (?) jug (8) and graphite-burnished (?) pot (38): $<800{ }^{\circ} \mathrm{C}$, graphite-burnished (?) mug (27): 800-900 ${ }^{\circ} \mathrm{C}$; graphite-burnished (?) bowl $(41)<850{ }^{\circ} \mathrm{C}$; bowl (13) $800-900{ }^{\circ} \mathrm{C}$. Based on the firing temperatures it can be concluded that fine-wares, which received more attention during raw material preparation, shaping and surface treatment, were fired at higher temperatures. Conversely, household ceramics seem to be unevenly fired.

Significant differences in firing temperatures of wheel-turned (35) and hand-formed (8., 13., 27., 37., 38., 41., 43.) ceramics could not be observed. Therefore it is supposed that the differently manufactured ceramics were fired with similar methods under more or less similar conditions. However, only one wheel-turned ceramic was 
subjected to XRD, therefore the comparison of firing temperatures of wheeled and hand-formed ceramics cannot be considered representative. Unfortunately traces of ceramic firing locations could not be identified on the site; nevertheless, the above-mentioned temperature ranges could be achieved either though pit, open-air, or kiln firing. ${ }^{222}$

XRD analysis was also used to examine whether the burnishing on several vessels was made by graphite. Graphite was detected on vessel surfaces in three cases: Vekerzug biconical jar (8, firing: $<800{ }^{\circ} \mathrm{C}$ ), Hallstatt bowl (13, firing: 800-900 ${ }^{\circ} \mathrm{C}$ ), Vekerzug bowl (37, firing: 800-900 ${ }^{\circ} \mathrm{C}$ ). Graphite was not detected on the supposedly graphite burnished Hallstatt cup (27, firing: 800-900 ${ }^{\circ} \mathrm{C}$ ), bowl (41, firing: $<850{ }^{\circ} \mathrm{C}$ ), and pot (Sample 38, firing: $\left.<800{ }^{\circ} \mathrm{C}\right) .{ }^{223}$ It is very likely that these vessels were also graphite coated prior to firing but it burnt off during the firing process and only the 'graphite shine' remained. The firing temperature of the Hallstatt type mug (27) and bowl (41) fall within the temperature range in which graphite burnt off during our earlier experiments on graphite coating. ${ }^{224}$ The firing temperature of the biconical pot (38) displays a value lower than $800{ }^{\circ} \mathrm{C}$, although the disintegration of graphite also depends on the duration of firing. In this case graphite may also have burnt off. Nevertheless, graphite burnishing reflects the increased technological knowledge and expertise of potters. It may also signify specialized ceramic production, since it requires very well controlled firing conditions all through the firing process.

\subsection{Summary}

In this study, the technological features of 44 ceramics were compared. Three Vekerzug and five Hallstatt type ceramics from the examined assemblage were also analyzed by LA-ICP-MS and XRD methods. Based on the results of LA-ICP-MS, Hallstatt type ceramics were also locally produced (41: bowl, 27: mug). Petrographic analysis also underlines the local nature of Hallstatt ceramics, since the technological characteristics (raw materials, tempers, building techniques, and firing conditions) of Hallstatt type ceramics are similar to those of the Vekerzug vessels.

Considering the raw materials of the ceramics, most of the volcanic rock fragments observed in Vekerzug type ceramics from Nagytarcsa occur in the Visegrád and Börzsöny Mountains. Due to the geographical location of these mountain ranges and of the River Danube, the rock formations are similar on both sides of the Danube in the Danube Bend region and in the broader vicinity of Nagytarcsa. Therefore, it cannot be excluded that assumed Hallstatt imports, which display a similar composition to local Vekerzug types (4, 41: bowl; 25, 27: mug), may have been imported since the Danube's right bank, where the sediments might be similar to those of the left bank, belonged to the territory of the Hallstatt Culture. Consequently, the results do not exclude the possibility of ceramic trade. However, based on the extensive similarities in manufacturing technology and firing it is also likely that Hallstatt type vessels were produced at Nagytarcsa. It can easily be ascertained that individuals, including potters, moved from one community to another and continued their traditions. Similar conclusions were drawn for Bronze Age sites, where the technological features of Middle Bonze Age cultures could be identified in the ceramic technology of the Tumulus culture. ${ }^{25}$ According to recent research results, a more peaceful relationship can be assumed between the Vekerzug and Hallstatt communities from the $6^{\text {th }}$ century BC onwards than previously supposed. ${ }^{226}$ As a result, Hallstatt individuals may have moved to the Vekerzug community at Nagytarcsa and produced Hallstatt type vessels - the form of which were not typical for the region East of the Danube - from local clay raw materials. If a potter moves to a different community he/she may continue to practice their traditional pottery production in the new community. ${ }^{227}$ In this way, the appearance or even survival of different ceramic traditions might be possible in the new community, even while new forms appear.

The typological diversity (size and shape of the vessels, bottom and handle form, variety in decoration patterns) and the diversity in the composition of ceramic raw materials may indicate that vessels were produced by several potters, or even pottery workshops. Based on the archaeological interpretation, intensive ceramic production cannot be assumed at Nagytarcsa due to the low number of ceramics, although this might be the result of the limited size of the excavation. Nevertheless, the examined ceramics represent high raw material diversity; even similar vessels were made from different raw materials. Coarse sand tempering appears in household ceramics. This rough

\footnotetext{
${ }^{222}$ Gosselain 1992, 246, Fig. 1; BlinMan-Swink 1997,

92, Fig. 6; Kingery 1997, 15, Fig. 4; Sillar 2000, 65.

${ }^{223}$ The handle fragment of a Hallstatt type cup (Fig. 15.11, Sample 27 on Fig. 20.7) was examined using XRD.
}

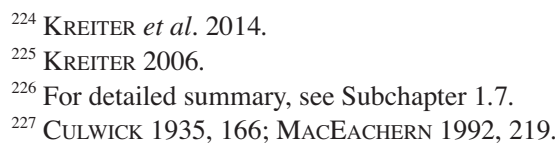

${ }^{224}$ KREITER et al. 2014.

${ }^{226}$ For detailed summary, see Subchapter 1.7. 
tempering is only typical for these types of ceramics and this might be for functional reasons. In case of vessels regularly exposed to heat (e.g. cooking), the coarse-grained fabric is advantageous because it makes ceramics more resistant to repeated heating and cooling. ${ }^{228}$ The common appearance of wheeled and hand-formed ceramics, as well as those produced with a combined technique, and the use of graphite reflect diversification and possibly specialization within the ceramic production of the site.

\section{FAUNAL REMAINS OF THE SCYTHIAN AGE SETTLEMENT (BEÁTA TUGYA)}

\subsection{Introduction}

Features excavated at the multi-period site contained animal bones in significant numbers: in 2007 altogether 3705 pieces, whilst in 2009 altogether 199 pieces were recovered. Most of the finds are associated with settlement features of the Roman Imperial Age barbarians, but smaller bone assemblages representing the Neolithic, the Middle Copper Age, the Late Bronze Age, the Scythian Period, and the Árpádian Period were also brought to light. The focus of this study is on the Early Iron Age finds: 201 fragments of animal bones from 19 features. In general, the finds were taphonomically well preserved with only a few bones in poor condition. Only small numbers of animal bone were recovered from most of the Scythian features; their number varied between 1 and 13. More than half of the entire archaeozoological material, 114 pieces, was concentrated in Feature 26/26. The finds were medium sized and not very fragmented: only $11 \%$ of the bones were smaller than $5 \mathrm{~cm}$. The majority of the finds (53\%) fell into the size range of 5-10 cm, whilst one-third of them were bigger than $10 \mathrm{~cm}$. The find material can be characterised as typical, moderately fragmented kitchen waste.

The measurements used in the study are in accordance with the generally accepted international standards of archaeozoology. ${ }^{229}$ Age determination is based on E. Schmid's work. ${ }^{230}$ Photographs of Fig. 27 were taken by Pál Kenéz, and the table was prepared by József Bicskei. Their work is appreciated. Only a few publications exist on this archaeological period, therefore this study provides new data on Scythian animal husbandry and hunting practices.

\subsection{Description and analysis of the finds}

All faunal remains in the entire archaeozoological assemblage could be identified. Bones of domestic animals comprise 99\% (199 pcs) of the 201 animal bone specimens; the remaining 1\% (2 pcs) are from wild animals. The following species were identified, in order of frequency: cattle - small ruminants - domestic pig - horse - dog - aurochs - red deer (Table 1).

Based on the bone finds, the calculated minimum number of individual animals is 17 . This number indicates the lowest possible number of individual animals whose bones were found in the material. When determining the minimum number of individuals, the following need to be taken into account: both the right and the left side fragments of anatomically identical bones of each species, the estimated age of the animal based on the bone finds, and the more precisely defined age based on the teeth finds. The order of the species, which is established on the basis of the minimum number of individuals only partly overlaps with the frequency of the bones of the species. Besides cattle, domestic pig bones belong to at least four individuals. The minimum number of small ruminants is estimated at four, of these one was a sheep. The minimum number of horse was two, whilst bones from a dog and of hunted species (aurochs and red deer) totalled a minimum of one each. The anatomical and taxonomical distribution of the bones can be studied on Table 2; bone measurements of each species are shown in Table 3.

${ }^{228}$ STEPONAITIS 1984; WoOdS 1986; Rice 1987, 229; HOARD et al. 1995; TITE et al. 2001.

\footnotetext{
${ }^{229}$ DRIESCH 1976.

${ }^{230}$ SCHMID 1972
} 
Table 1. The list of animal bone finds of the site Nagytarcsa-Urasági-dülö

\begin{tabular}{|c|c|c|c|}
\hline Species & NISP & $\%$ & MNI \\
\hline Cattle (Bos taurus L. 1758) & 126 & 62,7 & 4 \\
\hline Sheep (Ovis aries L. 1758) & 1 & \multirow{2}{*}{19,9} & 1 \\
\hline Sheep/Goat (Caprinae Gray 1821.) & 39 & & 3 \\
\hline Pig (Sus domesticus Erxl. 1777) & 21 & 10,4 & 4 \\
\hline Horse (Equus caballus L. 1758) & 8 & 4 & 2 \\
\hline Dog (Canis familiaris L. 1758) & 4 & 2 & 1 \\
\hline Domestic animals & 199 & 99 & 15 \\
\hline Aurochs (Bos primigenius Boj. 1827) & 1 & 0,5 & 1 \\
\hline Red deer (Cervus elaphus L. 1758) & 1 & 0,5 & 1 \\
\hline Wild animals & 2 & 1 & 2 \\
\hline Total & 201 & 100 & 17 \\
\hline
\end{tabular}

Cattle (Bos taurus L. 1758)

Cattle is the most abundant species of the site with 126 finds, comprising $62.7 \%$ of the entire bone material. The minimum number of individuals is four, of which two were calves younger than 2-years-old, one cattle was around 3.5-4-years-old, and one was an adult specimen of at least 4 years of age. Traces of butchering can be seen on a few cattle bones. The long bones were mostly chopped into two pieces, though on the medial side of one of the ulnas parallel running traces left by a cleaver can be observed.

A small, short squabby cattle horn core (Fig. 27.1) was recovered from Pit 26/26. The outward curve of the horn core is $96 \mathrm{~mm}$, its basal circumference is $138 \mathrm{~mm}$, its greatest diameter is $48.7 \mathrm{~mm}$, and its least diameter is $38.9 \mathrm{~mm}$. An additional but even smaller cattle horn core was found in the material. Its total length was not measurable, however its basal circumference $(94 \mathrm{~mm})$, its greatest diameter $(29.8 \mathrm{~mm})$, and its minimum diameter $(21.2 \mathrm{~mm})$ was measurable.

Based on two intact metatarsal bones the withers height of the animals could be estimated, ${ }^{231}$ their sex identified. ${ }^{232}$ One of them was a cow with a withers height of $107 \mathrm{~cm}$ (Fig. 27.2), the other a cow or an ox with a withers height of $113 / 114 \mathrm{~cm}$. The metatarsus of the latter displayed traces of use-wear: the frontal, dorsal side of the bone was polished, producing a shiny surface (Fig. 27.3), and the ends of the bone had been exposed to strong friction. Since it is a left side bone, the same side of its diaphysis is more worn. The direction of the use-wear traces and the friction could not be accurately observed. Bones that are worn on their dorsal side are often called bone skates, but their key feature is the distal epiphysis carved to a point. Usually a hole is drilled in the mediolateral side so it can be affixed. All these key features are missing from the Nagytarcsa material, therefore they are identified instead as bones used for abrasion, not skates. These bone tools are used to smooth a surface or to thin out a material. ${ }^{233}$ The glossy use-wear on the surface of the bone indicates that it was in contact with softer surfaces like leather.

\section{Sheep, sheep/goat (Ovis aries L. 1758; Caprinae Gray 1821)}

The differentiation of sheep and goat bones is only possible based on characteristic traits of certain bones. ${ }^{234}$ In the Nagytarcsa bone assemblage, one middle-sized horn core derives from sheep (Fig. 27.4), the remaining 39 finds can only be identified as sheep/goat. Their relative ratio is $19.9 \%$. The minimum number of individuals, calculated on the basis of the bone finds, is four. One sheep was definitely amongst them. Their age distribution is mixed. The majority were young animals, which indicates that the animals were butchered for their meat.

The material did not contain any intact long bones suitable for wither height calculation.

Dogs that lived on the settlement gnawed both ends of a radius. Tooth traces are visible on the diaphysis (Fig. 27.5). Similar traces are also visible on a fragment of a tibia.

$$
\begin{aligned}
& { }^{231} \text { Tsalkin } 1960 . \\
& { }^{232} \text { Nobis } 1954 .
\end{aligned}
$$

\footnotetext{
${ }^{233}$ KÖRÖSI 2010, 104

${ }^{234}$ BoEsSNeCK 1969.
} 
Domestic pig (Sus domesticus Erxl. 1777)

With 21 bones, the domestic pig was the third most abundant species at the settlement. The minimum number of individual pigs is four. Besides the youngest, a 0.75 -year-old piglet, there were two juvenile animals (younger than 2.5-years-old), and a sub-adult (2.5-3.5-years-old). Amongst domestic animals, pigs are usually butchered before they reach their full weight. The reason for this practice is that this species is exclusively a meat livestock, its period of pregnancy is relatively short, and it gives birth to multiple offspring. None of the intact bones were suitable for wither height calculation, and measurable long bones were not recovered either.

Horse (Equus caballus L. 1758)

Only 8 pieces of horse bone remains were recovered from the Scythian Period features. The horse is the fourth most abundant species from the excavated part of the settlement, though its ratio is not higher than $4 \%$. The minimum number of individuals is 2 . Both specimens come from adult animals, which might indicate the high value and appreciation of the species. Traces of butchering were not detectable on the bones, however, only one carpus was intact. Two bones were recovered from an oven, though they were not burnt. It was not possible to calculate wither height, and because of the lack of measurable parameters the size of the horses cannot be estimated.

\section{Dog (Canis familiaris L. 1758)}

The find material contained 4 pieces of dog bones (2\%). At least one adult dog could be identified. Besides their bones, the gnawed bones of the other animals also suggest the presence dogs. Dogs are active factors in taphonomic processes: they played a significant role in destroying bones. During the archaeozoological examination it can only be seen how many bones were gnawed, not how many were entirely consumed..

The dogs were not only kept to protect the house, the properties, and to clean up kitchen waste: two bones were recovered bearing marks that confirm at least the occasional consumption of dog meat. At least three longer butcher marks could be identified on a cleaved dog skull, and on the ventral side of one of the second cervical vertebra (axis). The skull was hit with several strong chops before they succeeded in dividing it into two parts. The aim was to access the brain and marrow. Cut marks on the vertebra are almost parallel, not deep, and probably the vertebra was cut with a knife. ${ }^{235}$

In one of the Scythian Period features at the Ludányhalászi-Sóderbánya archaeological site, a few chopped dog bones were observed. Amongst these one cervical vertebra, one thoracic vertebra, one pelvic vertebra, as well as three metatarsi were found. Formerly, there was no information on dog meat consumption in the Scythian Period. Previous observations made during archaeological and archaeozoological studies suggested that dog meat was not consumed after the Bronze Age in the territory of Hungary. ${ }^{236}$

\section{Aurochs (Bos primigenius Boj. 1827)}

The only aurochs remain was a fragment of the first cervical vertebra (atlas) from an adult animal. The find is heavily petrified, its preservation is poor. Aurochs remains are scarce on Scythian Period sites. One find is known from the Jászfelsőszentgyörgy-Túróczi-tanya archaeological site (older than the one from Nagytarcsa) ${ }^{237}$ while at Salgótarján-Ipari park II, seven aurochs bones were recovered. ${ }^{238}$

\section{Red deer (Cervus elaphus L. 1758)}

Only one red deer find - a fragment of the upper molar from an adult animal - indicates that this cervid species was hunted. Red deer is one of the most common animal finds in the Iron Age (especially in its late period), though it is only represented by a few finds. In the archaeozoological material from the Ludányhalászi-Sóderbánya archaeological site, more red deer remains can be found: two antlers and seven bone fragments. ${ }^{239}$ One red deer bone fragment was recovered at Jászfelsőszentgyörgy-Túróczi-tanya. ${ }^{240}$

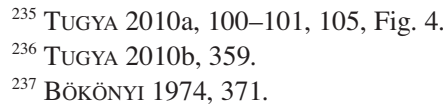

${ }^{237}$ ВӧKÖNYI 1974, 371.

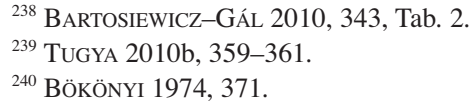



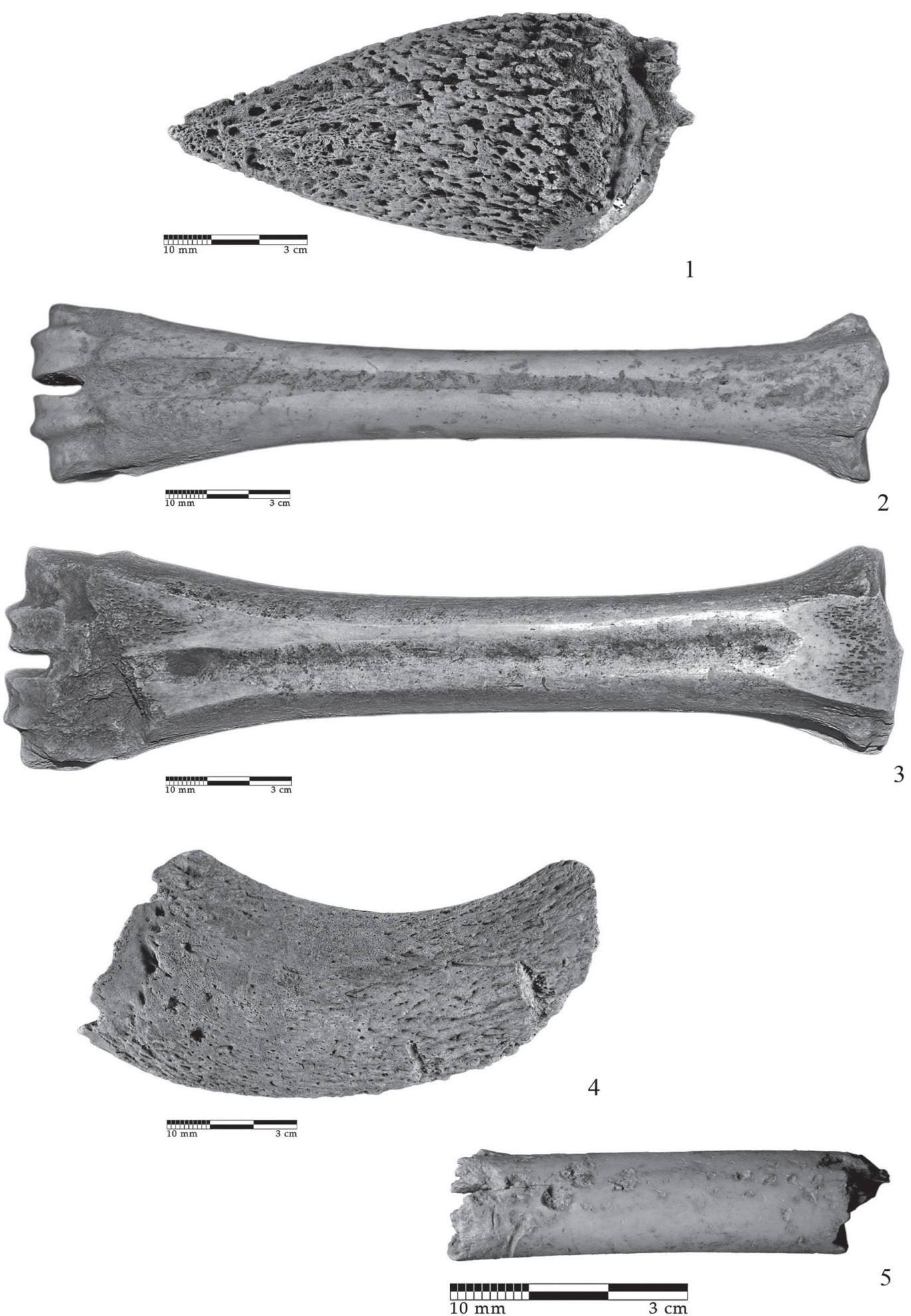

Fig. 27. Scythian Age animal bones from Nagytarcsa-Urasági-dűlö.

1: Horn core of cattle from Pit 26/26.; 2: Metatarsus of cattle from Pit 26/26.; 3: Tool made from the metatarsus of cattle, Feature 472/488.; 4: Horn core of sheep from Pit 26/26.; 5. Chewed radius of small ruminant species from Pit 564/774. 


\subsection{Evaluation, comparison}

The 22 stratigraphical units of the 19 features of the Scythian Period settlement at Nagytarcsa-Urasági-dülő only contained a small number of animal bones, no more than 201 pieces. The population of the settlement mostly met their meat needs by butchering domestic animals. Hunting played only a sporadic role. Among the domestic animals bones of all domesticated species could be found with the exception of chicken, which was rare in this period. No unambiguously identifiable goat bone was found. The frequency of the species from most common to the least common is the following: cattle - small ruminants - domestic pig - horse - dog - aurochs - red deer.

Animal husbandry and hunting practices of Scythian Period settlements show similarities across settlements. The ratio of hunting at Salgótarján-Ipari park II, ${ }^{241}$ and at Ludányhalászi-Sóderbánya ${ }^{242}$ did not exceed $4 \%$, though the greater abundance of wild animals can be seen. Besides wild bird bone remains from Salgótarján, roe deer, wild boar, hare, and fish bones were also found. Moreover, remains of bison were identified. The frequency of the domestic animals among the three archaeological sites compared here differs from one to the other. Salgótarján and Nagytarcsa show similar frequencies (cattle - small ruminants - domestic pig - horse - dog). In the Late Bronze Age (Early Iron Age) archaeozoological material of Ludányhalászi the following frequency could be ob-

Table 2. Anatomical breakdown of the studied Scythian Age bone material of the site Nagytarcsa-Urasági-dülő

\begin{tabular}{|c|c|c|c|c|c|c|c|}
\hline & Cattle & Sheep, Sheep/Goat & Pig & Horse & Dog & Aurochs & Red deer \\
\hline Horn core & 2 & $\begin{array}{c}1 \\
(\text { Sheep) }\end{array}$ & & & & & \\
\hline Cranium & 9 & 1 & & & 1 & & \\
\hline Maxilla & 2 & 2 & 4 & & & & \\
\hline Premaxilla & 1 & & & & & & \\
\hline Mandible & 19 & 6 & 3 & 1 & 1 & & \\
\hline Tooth & 3 & 3 & 2 & & 1 & & 1 \\
\hline Atlas & 2 & & & & & 1 & \\
\hline Axis & & 1 & & & 1 & & \\
\hline Cervical vertebrae & 1 & & & & & & \\
\hline Thoracic vertebrae & 3 & & & & & & \\
\hline Lumbal vertebrae & 2 & & 2 & & & & \\
\hline Costa & 20 & 2 & 3 & & & & \\
\hline Scapula & 5 & 3 & 1 & 1 & & & \\
\hline Humerus & 11 & & & & & & \\
\hline Radius & 8 & 6 & & & & & \\
\hline Radius + Ulna & 1 & & & & & & \\
\hline Ulna & 4 & 2 & & & & & \\
\hline Carpus & 1 & & & 1 & & & \\
\hline Metacarpus & 5 & 1 & 1 & & & & \\
\hline Pelvis & 4 & & 1 & 2 & & & \\
\hline Femur & 4 & 2 & 1 & & & & \\
\hline Patella & & & & 1 & & & \\
\hline Tibia & 5 & 5 & 2 & & & & \\
\hline Calcaneus & 2 & & & 1 & & & \\
\hline Metatarsus & 7 & 5 & & & & & \\
\hline Phalanx I & 3 & & & 1 & & & \\
\hline Phalanx II & & & 1 & & & & \\
\hline Long bone & 2 & & & & & & \\
\hline Total & 126 & 40 & 21 & 8 & 4 & 1 & 1 \\
\hline
\end{tabular}


Table 3. Bone measurements (mm) (GL - total length; Bp - proximal width; Dp - proximal depth; SB - width of diaphysis;

$\mathrm{SD}$ - depth of diaphysis; Bd - distal width; Dd - distal depth)

\begin{tabular}{|c|c|c|c|c|c|c|c|}
\hline Horn core & $\begin{array}{c}\text { Length } \\
\text { of the outercurvature } \\
\text { of the horn core }\end{array}$ & $\begin{array}{c}\text { Basal } \\
\text { circumference }\end{array}$ & $\begin{array}{c}\text { Greatest } \\
\text { diameter } \\
\text { of the base }\end{array}$ & $\begin{array}{c}\text { Least diameter } \\
\text { of the base }\end{array}$ & & & \\
\hline \multirow{2}{*}{ Cattle } & \multirow[b]{2}{*}{96} & 138 & 48,7 & 38,9 & & & \\
\hline & & 94 & 29,8 & 21,2 & & & \\
\hline Sheep & & 151 & 50,7 & 38,2 & & & \\
\hline Radius & GL & Bp & Dp & SB & SD & Bd & Dd \\
\hline \multirow{3}{*}{ Cattle } & & \multirow{3}{*}{76,3} & \multirow{3}{*}{36} & 38 & 19,8 & & \\
\hline & & & & 32,2 & 18,2 & & \\
\hline & & & & & & 58,6 & \\
\hline Metacarpus & GL & Bp & Dp & SB & SD & Bd & Dd \\
\hline \multirow{4}{*}{ Cattle } & & & 29,9 & & & & \\
\hline & & \multirow[t]{3}{*}{49,9} & 29,7 & & & & \\
\hline & & & & & 21,1 & & \\
\hline & & & & & & 50,8 & \\
\hline Tibia & GL & Bp & Dp & SB & SD & Bd & Dd \\
\hline Cattle & & & & & & & 43,4 \\
\hline Sheep/Goat & & & & 13,1 & 11 & & \\
\hline Metatarsus & GL & Bp & Dp & SB & SD & Bd & Dd \\
\hline \multirow{5}{*}{ Cattle } & 201,5 & 38,2 & 38,7 & 20,6 & 21 & 44,1 & 25,9 \\
\hline & 211,5 & 46,8 & & 27,1 & & 54,4 & \\
\hline & & 47,5 & 43,9 & & & & \\
\hline & & & & 22 & 19,4 & & \\
\hline & & & & 14,9 & & & \\
\hline
\end{tabular}

served: cattle - domestic pig - small ruminants - horse - dog. Finally, the faunal material of the Scythian age shows the following frequency: small ruminants - cattle - domestic pig - dog - horse, and other Equidae. It must be mentioned that the analysis and evaluation of the finds from Ludányhalászi and Salgótarján are still in progress, so we can only rely on preliminary dating from the analysis of archaeozoological material. This means the comparison between the main domestic animals of the sites may vary in the light of the results of the final report.

The archaeozoological record of the Scythian Period site of Ludányhalászi-Sóderbánya (Nógrád County) is composed of 768 pieces and significantly exceeds the faunal assemblage of Nagytarcsa. The frequency order of domestic animals differs slightly, because the number of domestic pig bones somewhat exceeds those of small ruminants. Based on the number of species, as well as the amount of the bones, hunting played a more significant role. Only aurochs bones are missing amongst the four big game animals (aurochs, red deer, wild boar, roe deer). In comparison to this, not only is there red deer present at Nagytarcsa, but one find represents aurochs as well. One find of both gray wolf and brown bear was recovered at Ludányhalászi. These finds are rare. The hunting of these animals was probably not an everyday practice. Small-game were represented by hare, and by one bird bone. Nevertheless, hunting activities only complemented the meat demands of the Scythian population at this site since the ratio of game bones were only $3.5 \%(25 \mathrm{pcs}){ }^{243}$

The Scythian Period archaeozoological record of the Balassagyarmat-Káposztások archaeological site (Nógrád County) was also composed of small numbers of animal bones. Based on the 252 finds, the three most abundant species were small ruminants, cattle, and domestic pig. Only a few wild animal bones were recovered. ${ }^{244}$

At the site of Ecser 6-Maglód 1 (Pest County) large number of Scythian animal bones was recovered, altogether 1123 pieces. In addition to the seven domestic animal species, a few bones of six game species (red deer, roe deer, wild boar, brown bear, hare and rodent species) are also part of the archaeozoological record. The ratio of

${ }^{243}$ TugYa 2010b, 357-358.

${ }^{244}$ BARTOSIEWICZ-GÁl 2010, 343, Tab. 2. 
domestic animal species to wild animal species is $97.8 \%$ to $2.2 \%$. The frequency order of the domestic animals is the following: cattle - horse - small ruminants - domestic pig - dog - chicken. Hunting only complemented animal husbandry of the larger species. ${ }^{245}$

In the small archaeozoological bone record (altogether 216 bones, from which only 83 were identifiable) from a (Late) Scythian Period feature at Hernádvecse (Borsod-Abaúj-Zemplén county) the dominance of domestic animals can be seen. Only a few remains of wild species were recovered (hare and hamster). Bones of big game animals did not occur. A single fish bones was also discovered here. The limited size of the archaeozoological record made it unsuitable for drawing far-reaching conclusions. The frequency order of the domestic animals was the following: sheep/goat - cattle - dog - domestic pig - horse. ${ }^{246}$

Altogether 136 identifiable animal bones were recovered from a Scythian Period well at Békéscsaba. With the exception of one bone, all of the bones derive from domestic animals. Their order is the following: domestic pig - cattle - sheep/goat - horse - dog. Similarly to the above-mentioned feature from Hernádvecse, faunal remains of big game were not present; hunting activities were only shown by the presence of a single hare bone. ${ }^{247}$

The bone record from a single feature neither represents the total overview of a population's lifestyle, nor does it provide the exact number and ratio of domestic and hunted wild species. That said, the analysis of the faunal remains of Békéscsaba, Hernádvecse, and the other above-mentioned sites, shows that domestic animals dominated Scythian Age settlements. Hunting was a complementary and sporadic activity in the life of these societies.

\section{REFERENCES}

AlEXANDRESCU 1977

AugIER et al. 2013

BAKAY 1971

BARTOSIEWICZ-GÁL 2010

BESSONOVA-ROMANYUK 2004

BLINMAN-SWINK 1997

BoESSNECK 1969

BÓKA 2007

BÓKA-TUGYA 2007

BORSY 1989

BOTTYÁN 1955

BÖKÖNYI 1974
$=$ P. Alexandrescu: Les modéles Grecs de la céramique Thrace tournée. Dacia 21 (1977) 113-137.

$=$ L. Augier-I. Balzer-D. Bardel-S. Deffressigne-É. Bertrand-F. Fleischer-S. HopertHagmann-M. Landolt-C. Mennessier-Jouannet-C. Mège-M. Roth-Zehner-M. Saurel-C. TAPPERT-G. ThiERrin-MichaEL-N. TikONOFF-M. RufFIEUX-M. VAN Es: La céramique façonnée au tour : témoin privilégié de la diffusion des techniques au Hallstatt D2-D3 et à La Tène A-B1. In: L'âge du Fer en Aquitaine et sur ses marges. Mobilité des hommes, diffusion des idées, circulation des biens dans l'espace européen à l'âge du Fer. Actes du $35^{\mathrm{e}}$ Colloque international de l'AFEAF (Bordeaux, 2-5 juin 2011). Éd.: A. Colin, F. Verdin. Aquitania Supplément 30. Bordeaux: Fédération Aquitania Maison de 1'Archéologie 2013, 563-94.

$=$ K. BAKAY: Scythian Rattles in the Carpathian Basin and Their Eastern Connections. Budapest: Akadémiai Kiadó 1971.

= L. Bartosiewicz-E. GÁL: Archaeozoological finds in Nógrád County, Northern Hungary. In: „Régről kell kezdenünk...” Studia archaeologica in honorem Pauli Patay. Régészeti tanulmányok Nógrád megyéből Patay Pál tiszteletére. Ed.: Sz. Guba, K. Tankó. Szécsény: Gaál István Egyesület 2010, 337-352.

= С. С. Бессонова-В. В. Романюк: Поселення скіфского часу на території м. Тараща (Scythian settlement at the territory of the town of Tarascha). ArhKiev 2004/2 (2004) 90-102.

$=$ E. Blinman-C. Swink: Technology and organization of Anasazi trench kilns. In: The Prehistory and History of Ceramic Kilns. Ed.: P. M. Rice. Ceramics and civilization 7. Westerville, Ohio: The American Ceramic Society 1997, 85-102.

= J. Boessneck: Osteological differences between sheep (Ovis aries Linné) and goat (Capra hircus Linné). In: Science in Archaeology. Eds: D. Brothwell, E. Higgs. New York: Thames and Hudson 1969, 331-358.

= G. BóKA: Addig jár a korsó a kútra... Vaskori kutak Békéscsaba határából (The pitcher goes so long to the well... Iron Age wells from the outskirts of Békéscsaba). BMMK 30 (2007) 111-150.

= G. BóKA-B. TugYA: Egy békéscsabai szkíta kút állatcsontleletei (Animal bone finds of a Scythian well in Békéscsaba). BMMK 30 (2007) 151-161.

= Z. Borsy: Az Alföld hordalékúpjának negyedidőszaki fejlödéstörténete [The evolution of the quaternaly alluvial fan of the Great Hungarian Plain]. FrÉ 38 (1989) 211-224.

= Á. BotTyÁn: Szkíták a magyar Alföldön [Scythians on the Great Hungarian Plain]. RégFüz 1. Budapest : MNM - Történeti Múzeum 1955.

= S. BöKÖNYI: History of Domestic Mammals in Central and Eastern Europe. Budapest: Akadémiai Kiadó 1974.

245 TUGYA in press.

${ }^{246}$ DARÓCZI-SZABÓ 2008, 107.
${ }^{247}$ BÓKA-TugYa 2007, 154. 
BUJNA-ROMSAUER 1983

BUJNA-ROMSAUER 1984

Cattani 1994

ChÁvez 1992

ChOchorowski 1985

CHOchOROWSKI 1996

CHOCHOROWSKI 1998

ČILINSKÁ 1959

CSALOG-KISFALUDI 1985

CSEH 1990

CSEH 2001

CSEH 2005

CSEH 2006

CSEH 2008

CSEH 2009

CSEH-KrIVECZKY 2001

Culwick 1935

CZIFra 2006

CZIFra 2016

CZIFra et al. 2011
= J. BujnA-P. RomSAUER: Späthallstatt- und frühlaténezeitliches Gräberfeld in Bučany. S1A 31/2 (1983) 277-324.

= J. BuJNA-P. RomSAUER: Halštatské sídlisko v Hostiach (Hallstattzeitliche Siedlung in Hoste). SlA 32/2 (1984) 431-452.

= M. CATTANi: Late Bronze and Iron Age dwellings and pits in Endrőd 19 (S.E. Hungary). In: The Archaeology of the Steppes. Methods and strategies. Papers from the International Symposium held in Naples, 9-12 November 1992. Ed.: B. Genito. Seria Minor/Università degli Studi di Napoli L'Orientale 44. Napoli Istituto Universitario Orientale Dipartimento di Studi Asiatici 1994, 209-219.

= M. K. L. CHÁvEZ: The organization of production and distribution of traditional pottery in south Highland Peru. In: Ceramic Production and Distribution: An integrated approach. Eds: G. J. Bey III, C. A. Pool. Westview special studies in archaeological research. Oxford: Westview Press 1992, 49-92.

= J. Chochorowski: Die Vekerzug-Kultur. Charasterik der Funde. PArch 36. Warsawa-Kraków: Uniwersitet Jagelloňski; Państwowe wydawnictwo naukowe 1985.

= J. CHOchorowski: Problem recepcji elementów kultury antycznej (greckiej) w kotlinie Karpackiej w VI w. p. n. e. Na marginesie dyskusji o genezie tzw. Ceramiki toczonej (Problem der Rezeption der Elemente der antiken (griechisen) Kultur im Karpatenbecken im 6. Jh.v.u.Z. - Ein Diskussionsbeitrag zur Genese der sog. Grauen Drehscheibenkeramik). In: Problemy epoki brąu i wczesnej epoki żelaza w Europie Środkowej. Księga jubileuszowa poświęcona Markowi Gedlowi (Probleme der Bronze- und frühen Eisenzeit in Mitteleuropa. Festschrift für Marek Gedl zum 60. Geburtstag und zum 40. Jahrestag der wissenschaftlichen Tätigkeit an der Jagiellonen-Universtät). Hrsg.: J. Chochorowski. Kraków: Ofycina Cracovia 1996, 115-147.

= J. CHOchorowski: Die Vekerzug-Kultur und ihre östlichen Beziehungen. In: Das Karpatenbecken und die osteuropäische Steppe. Nomadenbewegungen und Kulturaustausch in den vorchristlichen Metallzeiten (4000-500 v.Chr). Hrsg.: B. Hänsel, J. Machnik. Prähistorische Archäologie in Südosteuropa 12. Rahden/Westf.: Marie Leidorf Gmbh 1998, 473-491.

= Z. ČILINSKÁ: Žiarový hrob kuštanovického typu v Michalovciach (Ein Brandgrab von KuštanoviceTypus in Michalovce). S1A 7/1 (1959) 79-86.

= Zs. CsALOG-J. KISFALUDI: Skythenzeitliches Gräberfelder in Törökszentmiklós-Surján-Újtelep. ActaArchHung 37 (1985) 307-344.

= J. CsEH: Egy szkíta ház Szolnok-Zagyvapartról [A Scythian house from Szolnok-Zagyvapart]. MúzLev 63-64 (1990) 3-18.

= J. CSEH: Szkíta földművelők-állattartók településeinek régészeti nyomai a Zagyva mentén (Településtörténeti kutatások Szolnok határában 1986-1990 között) [Archaeological traces of Scythian farmers-large livestock breeders along the river Zagyva (Settlement history researches in outskirts of Szolnok between 1986-1990)]. In: Hatalmasok viadalokban. Az Alföld szkíta kora (Sie sind in Kämpfen siegreich. Das Zeitalter der Skythen in der Tiefebene). Hrsg.: P. Havassy. Gyulai katalógusok 10. Gyula: BMMIg Erkel Ferenc Múzeuma; Katona József Múzeum; Móra Ferenc Múzeum 2001, 79-95.

= J. CSEH: Szkíta telepobjektum Besenyszög-Szórópusztán [Scythian settlement feature at Besenyszög-Szórópuszta]. MúzLev 80-81 (2005) 5-23.

= J. CsEH: Archaeologia Scythica. Adalékok a Közép-Tisza mente vaskori történetéhez (Archaeologica Scythica. Additamenta to history of the Middle Tisza region in the Iron Age). Tisicum SzMMÉ 15 (2006) 13-42.

= J. CSEH: Jászfelsőszentgyörgy-Túróczi-tanya. Településnyomok a rézkortól a népvándorlás korig - Csalog Zsolt 1961. évi ásatása (Jászfelsőszentgyörgy-Túróczi-tanya. Archaeological remains of settlements from the Copper Age to the Migration Period). Tisicum - SzMMÉ 17 (2008) 83-117.

= J. CsEH: Középső és késő vaskori (szkíta és kelta) települések nyomai Kengyel-Baghymajor mellett (Kengyelpart I.) (Vestiges of settlements from the Middle and Late Iron Ages on the site Kengyelpart I near Kengyel-Baghymajor). Tisicum - SzMMÉ 18 (2009) 35-44.

= J. CSEH-B. KRIVECZKY: Szkíta és szarmata telepleletek Tiszaigar határában (Skythische und sarmatische Siedlungsfunde in der Gemarkung von Tiszaigar). ComArchHung 2001, 51-63.

= G. M. CuLwick: Pottery among the Wabena of Ulanga, Tanganyika Territory. Man 35 (1935) 165-169.

= Sz. CzIFRA: Megjegyzések a szkíta kori Alföld-csoport veremházainak kérdéséhez (Bemerkungen zur Frage der Grubenhäuser der skythenzeitlichen Alföld-Gruppe). ArchÉrt 131 (2006) 169-178.

= Sz. CzIFRA: Szkíta kori település a Nyírségben: Nyírparasznya - III. forduló (Előzetes jelentés) (A Scythian period settlement in the Nyírség region: Nyírparasznya - III. - Preliminary report). In: RégKut 2011-2014. Ed.: J. Kvassay. Budapest: Forster Gyula Nemzeti Örökségvédelmi és Vagyongazdálkodási Központ; MNM 2016, 97-119.

= Sz. CzIFRA-A. Kreiter-É. SzÉLeS-M. Tóth-O. VikToriK: Kora vaskori korongolt kerámia a Kárpát-medencében (Early Iron Age wheel-turned pottery in the Carpathian Basin). Archeometriai Mühely/Archaeometrical Workshop 2011/3, 235-249. 
CZIFRA et al. 2015

DANI et al. 2006

DARÓCZI-SZABÓ 2008

DEBOER-LATHRAP 1979

DINNYÉS 2002

DRIESCH 1976

DULAR 1982

DULAR-KRIŽ 2004

ĎURKOVIČ 2007

ĎURKOVIČ 2009

DUŠEK 1966

DUŠEK 1979

FETTICH 1931

FOLTINY 1963

FRANK 1998

FREY 1969

FULLÁR 2012

GÁL-MoLNÁR 2004

GANINA 1965

GANINA 1984

GÁTI 2009

GÁTI 2014
= Sz. CZIFrA-A. KREITER-P. PÁNCZÉL: Typology versus petrography: analysis of unique Scythian Age cups from Nyírparasznya (NE Hungary). In: An der Grenze der Bronze- und Eisenzeit. Festschrift für Tibor Kemenczei zum 75. Geburtstag. Hrsg.: I. Szathmári. Budapest: Magyar Nemzeti Múzeum 2015, 49-63.

= J. DANI-K. A. SzILÁGYI-M. SzELEKovSZKY-SZ. CZIFRA-V. KISJUHÁSZ: Előzetes jelentés a Berettyóújfalu, Nagy Bócs-dűlő lelőhelyen 2004-2005 során végzett megelőző feltárásról - Preliminary report of the excavations preceeding investment at the Berettyóújfalu, Nagy Bőcs-dülö site in 2004-2005. In: RégKut 2005. Ed.: J. Kisfaludi. Budapest:Kulturális Örökségvédelmi Hivatal; Magyar Nemzeti Múzeum 2006, 5-31.

= M. DARÓCZI-SZABÓ: Archaeozoológiai vizsgálatok Hernádvécse 3-as lelőhely S3 szkíta kori telepobjektumán belül (Analysis of the archaeozoological sample from the Scythian feature from the Hernádvécse 3 site). HOMÉ 47 (2008) 107-111.

= W. DEBOER-D. LATHRAP: The making and breaking of Shipibo-Conibo ceramics. In: Ethnoarchaeology: Implications of ethnography for archaeology. Ed.: C. Kramer. New York: Academic Press 1979, 102-138.

= I. DinNYÉS: Gyál, 7-7A. lelöhely: szkíta teleprészlet - Gyál, site 7-7A: Scythian settlement fragment. In: RégKut 1999. Eds: E. Marton, J. Kisfaludi. Budapest 2002, 71-84.

= A. V. D. Driesch: A Guide to the Measurement of Animal Bones from Archaeological Sites: As developed by the Institut für Palaeoanatomie, Domestikationsforschung und Geschichte der Tiermedizin of the University of Munich. Peabody Museum Bulletins 1. Cambridge, Mass.: Peabody Museum of Archaeology and Ethnology; Harvard University 1976.

= J. DulaR: Halštatska keramika v Sloveniji. Prispevek k proučavanje grobne keramike in lončarstva na Dolenjskem (Die Grabkeramik der älteren Eisenzeit in Slovenien). Ljubljana: Slovenska akademija znanosti in umetnosti, Razred za zgodovinske in družbene vede 1982.

= J. DulaR-B. KRIŽ: Željeznodobno naselje na Cvingerju pri Dolenjskih Toplicah (Eisenzeitliche Siedlung auf dem Cvinger bei Dolenjske Toplice). AV 55 (2004) 207-250.

= É. DuRKovič: Újabb adatok a Kisalföld kora vaskori településszerkezetéhez (Recent contributions to the Early Iron Age settlement network of the Kisalföld). Arrabona 45/1 (2007) 11-60.

= É. ĎURKOVIČ: Kora vaskori topográfiai kutatások a Kisalföldön (Topographic studies on the Early Iron Age in the Little Hungarian Plain). Ösrégészeti Levelek 11 (2009) 95-113.

= M. DuŠEK: Thrakisches Gräberfeld der Hallstattzeit in Chotín. ASF 6. Bratislava: Vydavatel'stvo Slovenskej Akadémie Vied 1966.

= S. DUŠEK: Mineralogisch-archäologische Untersuchungen zur hallstattzeitlichen Drehscheibenkeramik der Südwestslowakei. SlA 27/1 (1979) 125-138.

= N. Fetтich: Bestand der skythischen Altertümer Ungarns, In: Skythien und der Bosporus. I.: Kritische Übersicht der schriftlichen und archäologischen Quellen. Hrsg. M. Rostowzew. Berlin: Hans Schoetz \& Co. Gmbh 1931, 494-529.

= S. FoltinY: Zur Frage des ,,skythischen” Einflusses in Ostösterreich und in Slowenien. ArchA 33 (1963) 23-36.

= B. E. FranK: Mande Potters and Leather Workers. Art and heritage in West Africa. Washington DC: Smithsonian Institution Press 1998.

= O.-H. FrEY: Die Entstehung der Situlenkunst. Studien zur figürlich verzierten Toreutik von Este. RGF 31. Berlin: Walter de Gruyter \& Co 1969.

= Z. FulláR: Nagytarcsa-Urasági-dűlő (Pest megye, 16. lelőhely). In: Field Service for Cultural Heritage 2009. Yearbook and Review of the Archaeological Investigations. Ed.: J. Kvassay. Budapest: MNM Nemzeti Örökségvédelmi Központ 2012, 18.

= K. GÁL-A. MolNÁR: „Sé-Doberdó. Az 1998-as és 2001-es ásatások vaskori leletanyaga” (Hallstattund latènezetitliche Siedlungsreste aus Sé, Komitat Vas. Savaria 28 (2004) 159-230.

= О. Д. ГАнІнА: Поселення скіфського часу у сель Іване-Пусте [Scythian Age settlement at IvanePuste]. ArhKiev 19 (1965) 106-117.

= О. Д. ГАнІнА: Поселення ранньоскіфскої доби поблизу с. Залисся [Early Scythian Age settlement in the vicinity of village Zalesye]. ArhKiev 47 (1984) 68-79.

= Cs. GÁTI: A szajki (Baranya megye) koravaskori telep kulturális kapcsolatai (Cultural contacts of the Early Iron Age settlement at Szajk, Baranya county). In: M $\Omega$ MO $\Sigma$ VI. Őskoros Kutatatók VI. Összejövetelének konferenciakötete. Nyersanyagok és kereskedelem. Kőszeg 2009. március 19-21. - Proceedings of the 6th Meeting for the Researchers of Prehistory. Raw Materials and Trade. Köszeg 19-21 March, 2009. Ed.: G. Ilon. Szombathely: Kulturális Örökségvédelmi Szakszolgálat; VMMIg 2009, 65-77.

= Cs. GÁtı: On the crossroads of cultures. Cultural and trade connections of the site of Szajk in South Transdanubia in the sixth-fourth centuries BC. In: Iron Age Crafts and Craftsmen in the Carpathian 
Genito 2008

GosSELAin 1992

GRÓH 1984

GUIDI 1994

GuTSAL 1979

GYUCHA 2001

GYUCHA 2002

HARMATTA 1967

HARMATTA 1968

B. Hellebrandt 1994

HELLMUTH 2006

HeLlmuth 2007

HOARD et al. 1995

HORVÁTH 2015

HUNYADY 1942-1944

ILON 1985

ISTVÁNOVITS 1997

JÁKY 2016

JEREM 1981

JEREM 1986

JEREM et al. 1984
Basin. Proceedings of the International Colloquium from Târgu Mureş 10-13 October 2013. Ed. S. Berecki. Târgu Mureş: Mega 2014, 115-138.

= B. GENITO: The archaeology of the steppes. The excavations at Endröd 19 (SE Hungary). A particular viewpoint. ActaArchHung 59 (2008) 353-372.

$=$ O. P. GosSELAIN: Bonfire of the inquiries - pottery firing temperatures in archaeology - what for? JAS 19 (1992) 243-259.

= D. GRÓH: Előzetes jelentés a Visegrád-Csemetekert lelőhelyen végzett későbronzkori és koravaskori feltárásról (Vorbericht über die spätbronze- und früheisenzeitliche Erschliedlung von VisegrádCsemetekert). ComArchHung (1984) 53-66.

= A. GuIDI: Pottery sequence and the Scythian Period in Endröd 19 (SE Hungary). In: The Archaeology of the Steppes. Methods and strategies. Papers from the International Symposium held in Naples, 9-12 November 1992. Ed.: B. Genito. Seria Minor/Università degli Studi di Napoli L'Orientale 44. Napoli: Istituto Universitario Orientale Dipartimento di Studii Asiatici 1994, 221-229.

= А. Ф. ГуцАл: Нові пам'яатки раннього залізного віку в Середньому Подністров'ї (розвидки 1968-1969 pp.) [New Early Iron Age monuments in the Central Dniester region (researches 19681969)]. ArhKiev 30 (1979) 65-75.

= A. GyuchA: A szkíta kor emlékei Békés megyében [Scythian antiquities in county Békés]. In: Hatalmasok viadalokban. Az Alföld szkíta kora (Sie sind im Kämpfen siegreich. Das Zeitalter der Skythen in der Tiefebene). Gyulai katalógusok 10. Hrsg.: P. Havassy. Gyula: BMMIg Erkel Ferenc Múzeuma; Katona József Múzeum; Móra Ferenc Múzeum 2001, 115-127.

= A. GyUcha: Újabb szkíta kori telepnyomok Békés megyéből (Later Scythian Age settlement vestiges from Békés County). BMMK 23 (2002) 59-89.

= J. HARMATTA: Kereskedelmi útvonalak a Kárpát-medence, Észak-Itália és Görögország között a korai vaskorban (Früheisenzeitliche Handelswege zwischen dem Karpatenbecken, Oberitalien und Griechenland). ArchÉrt 94 (1967) 133-136.

= J. HARMATtA: Früheisenzeitliche Beziehungen zwischen dem Karpatenbecken, Oberitalien und Griechenland. ActaArchHung 20 (1968) 153-157.

= M. B. HellebrandT: Kelta leletek Kistokaj-Kültelek területéről (Keltische Funde aus dem Gebiet von Kistokaj-Kültelek). HOMÉ 32 (1994) 55-94.

= A. Hellmuth: Smolenice-Molpír im Licht skythischer Angriffe auf die hallstattzeitlichen Siedlungen nördlich und südlich der Mährischen Pforte. SlA 54/2 (2006) 191-208.

= A. Hellmuth: Untersuchungen zum Gewicht skythischer Pfeilspitzen aus der hallstattzeitlichen Siedlung von Smolenice-Molpír. S1A 55/2 (2007) 285-294.

= R. J. Hoard-M. J. O'Brien-M. G. Khorasgany-V. S. Gopalaratnam: A material-science approach to understanding limestone-tempered pottery from the Midwestern United States. JAS 22 (1995) 823-832.

= L. HoRvÁTH: Középső vaskori öntőformák Alsópáhokról (Middle Iron Age moulds from Alsópáhok). ArchÉrt 140 (2015) 229-255.

= I. HunYADY: Die Kelten im Karpatenbecken - Kelták a Kárpátmendecében. DissPan I/18. Budapest: Kir. Magy. Pázmány Péter Tudományegyetem Érem- és Régiségtani Intézete 1942-1944.

= G. ILON: A Szob-Gregersen-kerti szkíta kori temetőrészlet (Ein skythenzeitliches Gräberfeld in Szob-Gregersengarten). StComit 17 (1985) 75-96.

= E. IsTVÁNOVITS: Nyíregyháza-Manda-bokor. Kora vaskori település a Kr.e. VI-IV. századból [Nyíregyháza-Manda-bokor. Early Iron Age settlement from VI-IV. B.C.]. In: Utak a múltba. Az M3-as autópálya régészeti leletmentései (Paths into the past. Rescue excavation on the M3 motorway). Eds: P. Raczky, T. Kovács, A. Anders. Budapest: MNM; ELTE Régészettudományi Intézet 1997, 73-79, 181-182.

= A. JÁKY: Periodization of settlement of Balatonboglár-Berekre-dülö in the Iron Age. In: Iron Age Chronology in the Carpathian Basin. Proceedings of the International Colloquium from Târgu Mureş 8-10 October 2015. Ed.: S. Berecki. Cluj-Napoca: Mega 2016, 97-117.

= E. JEREM: Zur Späthallstatt- und Frühlatènezeit in Transdanubien. In: Die Hallstattkultur. Bericht über das Symposium in Steyr 1980. Hrsg.: C. Eibner, A. Eibner. Linz: Kommission beim Oö. Landesverlag 1981, 105-136.

= E. JEREM: Bemerkungen zur Siedlungsgeschichte der Späthallstatt- und Frühlatènezeit im Ostalpenraum. In: Hallstattkolloquium Veszprém 1984. Hrsg.: E. Jerem. MittArchInst Bh 3. Budapest 1986 $107-123$.

= E. Jerem-G. FACSAR-L. Kordos-E. Krolopp-I. Vörös: A Sopron-krautackeri vaskori telep régészeti és környezetrekonstrukciós vizsgálata I. [Archaeological and environment reconstructional investigation of the Iron Age settlement discovered near Sopron-Krautacker I.]. ArchÉrt 111 (1984) $141-169$. 
JUREČKO 1981

JUREČKO 1983

KALICZ-Koós 1998

KASHUBA et al. 2012

KEMENCZEI 1977

KEMENCZEI 1984

KEMENCZEI 1989

KEMENCZEI 2000

KEMENCZEI 2003

KEMENCZEI 2007

KEMENCZEI 2009

KEMENCZEI 2010

KILIKOGLOU-VELKINIS 2002

KiLIKOGLOU et al. 1995

KILIKOGLOU et al. 1998

KINGERY 1997

KISFALUDI 2004

KovAČEVIĆ 2007

KOVAČEVIĆ 2008

KozUBovÁ 2013

KozUbovÁ et al. 2017

KÖRÖSI 2010
= P. JUREČKO: Mladohalštatský sídliskový objekt v Blažiciach-Bohdanoviciach, okr. Košice-vidiek (The Late Hallstatt settlement object at Blažice-Bohdanovce, the Košice-country distr.). AR 33/4 (1981) 384-392.

= P. JUREČKO: Výskum v Trstenom pri Hornáde (K problematike osídlenia východného Slovenska $\mathrm{v}$ závere 1. tisícročia pred n. 1.) (Ausgrabung in Trstené pri Hornáde - Zur Besiedlungsproblematik der Ostslowakei Ende des ersten Jahrtausends v. u. Z.). SlA 31/2 (1983) 415-442.

= N. KALICZ-J. Koós: Siedlungsfunde der Früheisenzeit aus Nordostungarn. In: Das Karpatenbecken und die osteuropäische Steppe. Nomadenbewegungen und Kulturaustausch in den vorchristlichen Metallzeiten (4000-500 v.Chr.). Hrsg.: B. Hänsel, J. Machnik. Prähistorische Archäologie in Südosteuropa 12. Rahden/Westf.: Marie Leidorf Gmbh 1998, 423-436.

= M. KASHUBA-O. LEVITSKI-M. DARAGAN: Research on early grey wheel-thrown pottery (mid 7th to 6th century B.C.) in the barbarian milieu of the Eastern Carpathian region. In: Technologieentwicklung und -transfer in der Hallstatt- und Latènezeit. Beiträge zur Internationalen Tagung der AG Eisenzeit und des Naturhistorischen Museums, Prähistorische Abteilung in Hallstatt 2009. Hrsg.: A. Kern, J. Koch, I. Balzer, J. Fries-Knoblach, K. Kowarik, C. Later, P. Ramsl, P. Trebsche, J. Wiethold. Beiträge zur Ur- und Frühgeschichte Europas 65. Langenweißbach: Beier \& Beran 2012, 103-107.

= T. KEMENCZEI: Hallstattzeitliche Funde aus der Donaukniegegend. FolArch 28 (1977) 67-90.

= T. Kemenczei: Spätbronzezeit Nordostungarns. ArchHung 51. Budapest: Akadémiai Kiadó 1984.

= T. KEMENCZEI: Koravaskori sírleletek az Alföldről az Őskori gyűjteményben (Grabfunde der Früheisenzeit von der Tiefebene in der Prähistorischen Sammlung). FolArch 40 (1989) 55-74.

$=\mathrm{T}$. KEMENCzEI: Adatok a szkíta kor kezdetének kérdéséhez az Alföldön (Beiträge zur Frage des Anfangs der Skythenzeit aud der ungarischen Tiefebene). FolArch 48 (2000) 27-53.

$=$ T. Kemenczer: The Middle Iron Age: Scythians in the Tisza region (7th-5th centuries B.C). In: Hungarian Archaeology at the Turn of the Millennium. Eds: Zs. Visy, M. Nagy, Zs. Kiss. Budapest: Ministry of National Cultural Heritage; Teleki László Foundation 2003, 179-183.

$=$ T. KeMENCZEI: Kannelierte Keramik in der skythenzeitlichen Alföld-Gruppe. FolArch 53 (2007) 41-62.

$=$ T. KEMENCZEI: Studien zu den Denkmälern skythisch geprägter Alföld Gruppe. IPH 12. Budapest: Magyar Nemzeti Múzeum 2009.

$=$ T. KEMENCZEI: Funde der skythisch geprägten Alföld-Gruppe in Transdanubien. FolArch 54 (20082009) [2010] 101-125.

$=$ V. KILIKOGLOU-G. VeKINIS: Failure prediction and function determination of archaeological pottery by finite element analysis. JAS 29 (2002) 1317-1325.

$=$ V. KiliKogloU-G. VeKINIS-Y. Maniatis: Toughening of ceramic earthenwares by quartz inclusions: an ancient art revisited. Acta Metallurgica et Materialia 43 (1995) 2959-2965.

= V. Kilikoglou-G. Vekinis-Y. Maniatis-P. M. DaY: Mechanical performance of quartz-tempered ceramics. I.: Strength and toughness. Archaeometry 40 (1998) 261-279.

= D. W. KINGERY: Operational principles of ceramic kilns. In: The Prehistory and History of Ceramic Kilns. Ed.: P. M. Rice. Ceramics and civilization 7. Westerville, Ohio: The American Ceramic Society $1997,11-19$.

= J. KISFALUDI: Szkíta kori temető a Nyáregyháza M5-4 autópálya nyomvonalában [Scythian Age cemetery on M5-4 motorway at Nyáregyháza]. StComit 28 (2004) 167-198.

= S. KovAČEvić: Karakterični nalazi kasnohalštatskog naselja u Zbelavi kod Varaždina i fibula tipa Velem - Charasteristic finds from the Late Hallstatt settlement at Zbelava near Varaždin and a Velem-type fibula. Prilozi Instituta za arheologiju u Zagrebu 24 (2007) 89-112.

= S. KovAČEvić: Osvrt na strukturu i keramičku proizvodnju kasnohalštatskog naselja u Zbelavi kod Varaždina - A look at the structure and ceramic production of the late Hallstatt settlement in Zbelava near Varaždin. Prilozi Instituta za arheologiju u Zagrebu 25 (2008) 47-80.

= A. Kozubová: Pohrebiská vekerzugskej kultúry v Chotíne na juhozápadnom Slovensku (Die Gräberfelder der Vekerzug-Kultur in Chotín in der Südwestslowakei). Dissertationes archaeologicae Bratislavenses 1. Bratislava: Univerzita Komenského 2013.

= A. KozubovÁ-M. Bielich-A. BistÁKovÁ-B. MilovÁ: Sídlisko vekerzugskej kultúry Lužiankach pri Nitre (Vekerzug Culture settlement in Lužianky near Nitra). In: Sedem decénií Petra Romsauera. Mimoriadne číslo časopisu venované životnému jubileu prof. Petra Romsauera. Studia Historica Nitriensia 21, Supplementum. Eds.: N. B. Pažinová, Z. Borzová. Nitra: IČO 2017, 411-435.

= A. KöRÖSI: Szarmata és avar kori csonteszközök Felgyö-Kettőshalmon (Typology of the worked bone implements from Felgyő-Kettőshalmi-dűlő). In: Csont és bőr. Állati eredetű nyersanyagok feldolgozásának története, régészete és néprajza - Bone and Leather. History, Archaeology and Ethnography of Crafts Utilizing Raw Materials from Animals. Eds: J. Gömöri, A. Körösi. Budapest: MTA VEAB Iparrégészeti és Archaeometriai Munkabizottság 2010, 99-116. 
KREITER 2006

KREITER 2007a

KREITER 2007b

KREITER 2009

KREIETR et al. 2010

KREITER et al. 2013

KREITER et al. 2014

KRISTIANSEN 1998

KROMER 1987

LANTOS 2011

LÁZÁR 1951

LÁZÁR 1955

LENGYEL 1964

MACEACHERN 1992

MARÁZ 1981

MAROSI-SOMOGYI 1990

D. Matuz 2000

MenNa 2006

MÉSZÁROS 2008

METZNER-NEBELSICK 2002
= A. KREITER: Kerámia technológiai vizsgálatok a Halomsíros kultúra Esztergályhorváti-alsóbárándpusztai településéröl: hagyomány és identitás (Technological examination of Tumulus culture pottery from Esztergályhorváti-Alsóbárándpuszta: tradition and identity). ZalaiMúz 15 (2006) $149-170$.

= A. KREITER: Kerámia technológiai tradíció és az idő koncepciója a bronzkorban (Ceramic technological tradition and the concept of time in the Bronze Age). Ösrégészeti Levelek 8-9 (2006-2007) $146-166$

= A. KREITER: Technological Choices and Material Meanings in Early and Middle Bronze Age Hungary: Understanding the active role of material culture through ceramic analysis. BAR IntSer 1604. Oxford: Archaeopress 2007.

= A. KREITER: Késő bronzkori kerámiák makroszkópos és petrográfiai vizsgálata - Macroscopic and petrographic analysis of the Late Bronze Age pottery. In: Település- és temetőfeltárás Dunaszentgyörgy határában. A 6 sz. föút 121+650 - 124+800 km szakasza között, a rehabilitációs munkálatokat megelőző régészeti feltárások (2007) eredménye - Settlement and Cemetery Excavations at the Borders of Dunaszentgyörgy. Ed.: J. Kvassay. VIA. Kulturális örökségvédelmi kismonográfiák/ VIA. Monographia minor in Cultural Heritage 1. Budapest: Kulturális Örökségvédelmi Szakszolgálat 2009, 88-114.

= A. KREITER-É. SzÉLES-M. TóTH-O. ViKTORIK: Kora vaskori kerámiák petrográfiai, LA-ICP-MS és XRD vizsgálata Nagytarcsa-Urasági dülő lelőhelyről [Petrographic, LA-ICP-MS and XRD analyses of Early Iron Age ceramics from the archaeological site Nagytarcsa-Urasági-dülö]. Hungarian National Museum Archaeology Database [online] (Available at: http://archeodatabase.hnm.hu/en/ node/983, Accessed on: 14 February, 2017).

= A. Kreiter-Sz. CZifra-É. SzÉles-M. Tóth-O. Viktorik: Petrographic, LA-ICP-MS and XRD analyses of Hallstatt ceramics from a Scythian Age settlement in north Hungary. In: Counterpoint: Essays in Archaeology and Heritage Studies in Honour of Professor Kristian Kristiansen. Eds: S. Bergerbrant, S. Sabatini. BAR IntSer 2508. Oxford: Archaeopress 2013, 477-490.

= A. KreITER-SZ. CZIFRA-Zs. BENDŐ-I. J. EgRI-P. PÁNCZÉL-G. VÁCZI: Shine like metal: an experimental approach to understand prehistoric graphite coated pottery technology. JAS 52 (2014) 129-142.

= K. KristiansEn: Europe before History. Cambridge: Cambridge University Press 1998.

= K. Kromer: Das östliche Mitteleuropa in der Frühen Eisenzeit (7.-5. Jh. v. Chr.). Seine Beziehungen zu Steppenvölkern und antiken Hochkulturen. JRGZM 33/1 (1987) 3-93.

= A. LANTOS: Szkita kori telep Dunavecse határában (A settlement of the Scythian Age in the vicinity of Dunavecse). In: A Barbaricum ösvényein... A 2005-ben Kecskeméten tartott tudományos konferencia előadásai [On the Paths of Barbaricum... Proceedings of the scientific conference at Kecskemét in 2005]. Eds: Á. Somogyári, Gy. V. Székely. Archaeologia Cumanica 1. Kecskemét: BKM Önkorm. Katona József Múzeuma 2011, 27-49.

= J. LÁZÁR: A Sághegykörnyéki hallstattkori tumulus-sírokról (Tumulus graves belonging to the hallstatt period from the surroundings of Sághegy). ArchÉrt 78 (1951) 36-42, T. XXI-XXXI.

= J. LÁZÁR: Hallstatt-kori tumulusok a Ság-hegy távolabbi környékéröl (Hallstattzeitliche Tumuli aus der weiteren Umgebung des Ságberges, Westungarn). ArchÉrt 82 (1955) 202-211.

= I. LENGYEL: A fazekaskorong megjelenésének kérdése a Nagyalföldön (Zur Frage des frühesten gebrauches der Töpferscheibe in der Grossen Ungarischen Tiefebene). FolArch 46 (1964) 25-32.

= S. MACEACHERN: Ethnicity and stylistic variation around Mayo Plata, northern Cameroon. In: An African Commitment. Papers in honour of Peter Lewis Shinnie. Eds: J. Sterner, N. David. Calgary: University of Calgary Press 1992, 211-230.

= B. MARÁZ: A szkítakori őslakosság Latène-kori továbbélése Kelet-Magyarországon (Régészeti adatok a Kárpát-medencei kelta-szkíta kapcsolatok kérdéséhez) (On the survival of the autochtonous population of the Scythian Age in Eastern Hungary. Archaeological data to the question of the Scythian-Celtic connections in the Carpathian Basin). JPMÉ 26 (1981) 97-119.

= S. Marosi-S. Somogyi: Magyarország Kistájainak katasztere I-II (Inventory of Microregions in Hungary I-II). Budapest: MTA Földrajztudományi Kutató Intézet 1990.

= E. D. MATUZ: A Szeged-Algyő 258. kútkörzet területén feltárt preszkíta temető (Das präskythische Gräberfeld im Brunnenbezirk 258 von Szeged-Algyő). MFMÉ-StudArch 6 (2000) 139-164.

= A. Menna: La ceramica protostorica del Bacino dei Carpazi: l'evidenza di Endrőd 19 (Ungheria Sud-Orientale). Napoli: Universitá degli Studi di 'L'Orientale”, Facolta di Lettere Filosofia 2006. [PhdDiss]

= O. MÉszÁros: Nagytarcsa, Urasági-dülő. In: RégKut 2007. Ed.: J. Kisfaludi. Budapest 2008, 251.

= C. MetZnER-Nebelsick: Der ,Thrako-Kimmerische” Formenkreis aus der Sicht der Urnenfelderund Hallstattzeit im südöstlichen Pannonien. Vorgeschichtliche Forschungen 23. Rahden/Westf.: Marie Leidorf 2002. 
METZNER-NeBELSICK 2010

MIROŠŠAYOVÁ 1987

MIROŠŠAYOVÁ 1994

MiROŠŠAYOVÁ 1999

MOLNÁR 2007

MOLNÁR 2013

Moscalu 1983

MRT 9

MRT 11

T. NÉMETH 1996

NÉMETI 1982

NÉMETI 1984

NoBIS 1954

PARZINGER-STEGMANN-RAJTÁR 1988

PATEK 1984

PÁRDUCZ 1940

PÁRDUCZ 1943

PÁRDUCZ 1952

PÁRDUCZ 1958

PÁRDUCZ 1965a

PÁRDUCZ 1965b

PÁRDUCZ 1966

PÁRDUCZ 1973

PCRG 2010

PLOG 1980

PoPOVIČ 1981

POPOVICH 1997
= C. MetZner-Nebelsick: Aspects of mobility and migration in the eastern Carpathian Basin and adjacent areas int he Early Iron Age $\left(10^{\text {th }}-7^{\text {th }}\right.$ centuries BC). In: Migration in Bronze and Early Iron Age Europe. Eds: K. Dzięgilewski, M. S. Przbyła, A. Gawlik. PArch 63. Kraków: Księgarnia Akademicka 2010, 121-51.

= E. Miroššayová: Problematika osídlenia východného Slovenska v dobe halštatskej (Settlements of East Slovakia in the Hallstatt Period). SlA 35/1 (1987) 107-164.

= E. MirošŠAYOvÁ: Sídlisko z neskorej doby halštatskej v Čečejovciach (Späthallstattzeitliche Siedlung in Čečejovce). SlA 42/1 (1994) 37-68.

= E. MirošŠAYOvÁ: Einflüsse der Hallstattkultur in der Ostslowakei. In: Archaeology of the Bronze and Iron Age. Experimental Archaeology, Environmental Archaeology, Archaeological Parks. Proceedings of the International Archaeological Conference Százhalombatta, 3-7 October 1996. Eds: E. Jerem, I. Poroszlai. Archaeolingua 9. Budapest: Archaeolingua 1999, 157-166.

= A. MolnÁR: Figyelemre méltó kora vaskori objektum Ménfőcsanak határából (A significant early Iron Age object from Ménföcsanak). Arrabona 45/1 (2007) 61-70.

= A. MolnÁR: Neuere Ausgrabungen hallstattzeitlichen Siedlungen in der umgebung von Györ. ZSNM 107 (2013) 185-198.

= E. Moscalu: Ceramica traco-getică [The Thraco-Getian Ceramic]. Bibliotheca muzeologică 1. Bucureşti: Muzeul Naţional de Istorie 1983.

= I. Torma (ed.): Pest megye régészeti topográfiája. XIII/2.: A szobi és a váci járás [Archaeological Topography of County Pest. XIII/3: The districts of Szob and Vác]. Magyarország régészeti topográfiája 9. Budapest: Akadémiai Kiadó 1993.

= I. TORMA (ed.): Pest megye régészeti topográfiája. XIII/3.: Az aszódi és a gödöllői járás [Archaeological Topography of County Pest. XIII/3: The districts of Aszód and Gödöllő]. Magyarország régészeti topográfiája 11. Budapest: MTA BTK Régészeti Intézet; Archaeolingua 2012.

= G. T. NÉMETH: Angaben zur hallstattzeitlichen Topographie des südlichen Teils der Kleinen Tiefebene. In: Die Osthallstattkultur. Akten des Internationalen Symposiums, Sopron, 10-14. Mai 1994. Hrsg.: E. Jerem, A. Lippert. Archaeolingua 7. Budapest: Archaeolingua 1996, 365-378.

= J. NÉMETI: Das späthallstattzeitliche Gräberfeld von Sanislău. Dacia N.S. 26 (1982) 115-144.

= J. NÉMETI: Contribuţii la istoricul hallstattului tîrziu din Nord-Vestul României în lumina noilor descoperiri arheologice (Beiträge zur Geschichte der späten Hallstattzeit im Nordwesten Rumäniens im Lichte der neuen archäologischen Entdeckungen). ActaMP 8 (1984) 129-146.

= G. NoBIS: Zur Kenntnis der ur- und frühgeschichtlichen Rinder Nord- und Mitteldeutschlands. Zeitschrift für Tierzüchtung und Züchtungsbiologie 63 (1954) 155-194.

= H. PARZinger-S. Stegmann-RajtáR: Smolenice-Molpír und der Beginn der Skythischer Sachkultur in der Südwestlowakei. PZ 63 (1988) 162-178.

= E. PATEK: Die nordosttransdanubische Hallstattgruppe: ein Überblick. MittArchInst 12-13 (19821983) [1984] 59-84, 305-330.

= M. PÁRDUCZ: Bronz-, szkíta-, La Tène- és germánkori temető Hódmezővásárhel-Kishomokon (Ein Gräberfeld in Hódmezővásárhely-Kishomok aus der Bronze-, Skythen-, La Tène- und Germanenzeit). Dolg 16 (1940) 79-99, T. V-XIII.

= M. PÁrdUCZ: Szkítakori temető Békéscsaba-Fényesen (A cemetery of the Scythian period in Békéscsaba-Fényes). ArchÉrt (1943) 50-63.

= M. PÁrdUCZ: Le cimetière Hallstattien de Szentes-Vekerzug, ActaArchHung 2 (1952) 143-172.

= M. PÁRDUCZ: Hejőkeresztúri szkítakori lelet (Scythian Age finds from Hejőkeresztúr). HOMÉ 2 (1958) 73-78.

= M. PÁRDUCZ: Western relations of the Scythian Age culture of the Great Hungarian Plain. ActaAntHung 13 (1965) 273-301.

= M. PÁRDUCZ: Graves from the Scythian Age at Ártánd (county Hajdú-Bihar). ActaArchHung 17 (1965) 137-231.

= M. PÁrduCZ: The Scythian Age cemetery at Tápiószele. ActaArchHung 18 (1966) 35-91.

= M. PÁrducz: Probleme der Skythenzeit im Karpatenbecken (Skythen-Urbevölkerung). ActaArchHung 25 (1963) 27-63.

$=$ The Study of Later Prehistoric Pottery: General policies and guidelines for analysis and publication. Prehistoric Ceramic Research Group: Occasional papers 1-2. Chelmsford 2010, 3rd rev. edition.

= S. Plog: Stylistic Variation in Prehistoric Ceramics. Cambridge: Cambridge University Press 1980.

= D. Popovič: Keramika starijeg gvozdenog doba u Sremu (Die Keramik der älteren Eisenzeit in Syrmien). Fontes archaeologiae Iugoslaviae 4. Beograd: Savez Arheoloških društava Jugoslavije - Zavod za zaštitu spomenika kulture 1981.

= I. PoPOVICH: Periodization and chronology of Kushtanovica type sites in the Transcarpathian region. JAMÉ 37-38 (1995-96) [1997] 77-114. 
PoPOVICH 2006

RICE 1987

ROMSAUER 1991

ROMSAUER 1993

ROMSAUER 1996

SCHMID 1972

ScholTz 2007

SCHWELLNUS 2009

SILlAR 1997

SILLAR 2000

ŠINKOVEC-KRKALO 1994

SMIRNOVA 1977

SMIRNOVA 1981

SMIRNOVA 1997

SMIRNOVA 2001

STEGMANN-RAJTÁR 1996

StegmanN-RAJTÁR 2009

STEPONAITIS 1984

SZABÓ 2007a

SZABÓ 2007b

SZABÓ et al. 2007

SZABÓ-TANKÓ 2007

SZABÓ-FeKete 2011

V. SzABÓ et al. 2014
= I. Попович: Закарпаття за доби раннього заліза [Transcarpathia in the Early Iron Age]. KrakówLwów: Институт Археології Ягеллонського Университету; Институт Українознаства им. I. Крип'якевича Національної; Академії Наук України 2006.

= P. M. Rice: Pottery Analysis: A sourcebook. Chicago: University of Chicago Press 1987.

= P. RoMSAUER: The earliest wheel-turned pottery in the Carpathian Basin. Antiquity 65 (1991) 358-367.

= P. RomsaUER: Nové nálezy Vekerzugskej skupiny z Nitry (Neufunde der Vekerzug-Gruppe aus Nitra). SlA 41/1 (1993) 5-39.

= P. ROMSAUER: Bemerkungen zur Späthallstattzeit im Nordostalpenraum. In: Die Osthallstattkultur. Akten des Internationalen Symposiums, Sopron, 10-14. Mai 1994. Hrsg.: E. Jerem, A. Lippert. Archaeolingua 7. Budapest: Archaeolingua 1996, 431-444.

= E. ScHMID: Atlas of Animal Bones for Prehistorians, Archaeologists and Quaternary Geologists, Amsterdam-London-New York: Elsevier 1972.

= R. SchOLTZ: Szkíta kori település- és temetőrészlet Tiszalök határában (Tiszalök, Börtön) - Scythian Period settlement and cemetery fragment at Tiszalök (Tiszalök Prison). In: RégKut 2006. Ed.: J. Kisfaludi. Budapest: Kulturális Örökségvédelmi Hivatal; Magyar Nemzeti Múzeum 2007, 53-65.

= F. Schwellnus: Die Späthallstatt- bis Frühlatènezeit im Ödenburger Becken - Befund I der Siedlung Sopron-Krautacker/Ungarn. In: Architektur: Interpretation und Rekonstruktion. Beiträge zur Sitzung der AG Eisenzeit während des 6. Deutschen Archäologie-Kongresses in Mannheim 2008. Hrsg.: P. Trebsche, I. Balzer, C. Eggl, J. Fries-Knoblach, J. K. Koch, J. Wiethold. Beiträge zur Urund Frühgeschichte Mitteleuropas 55. Langenweißbach: Beier \& Beran 2009, 245-261.

$=$ B. SILlAR: Reputable pots and disreputable potters: individual and community choices in presentday pottery productions and exchanges in the Andes. In: Not so Much a Pot, More a Way of Life. Eds: C. G. Cumberpatch, P. W. Blinkhorn. Oxford: Oxbow 1997, 1-20.

= B. SILLAR: Shaping Culture: Making pots and constructing households. An ethnoarchaeological study of pottery production, trade and use in the Andes. BAR IntSer 883. Oxford: Archaeopress 2000.

= B. ŠInKOVEC-E. KRKALO: Graphite deposits from Mt. Psunj in Slavonia (Eastern Croatia). Geologia Croatica 47/1 (1994) 117-126.

$=$ Г. И. СмирновА: Курганный могильник раннескифского времени у села Долиняаны (Early Scythian barrows at Dolinyany). ASGE 18 (1977) 29-40.

$=$ Г. И. Смирнова: Новые данные о поселении у с. Долиняны (по материалам раскопок $1977-$ 1978. гг.) [New data on the Dolinyany settlement (according to the excavations of 1977-1978)]. ASGE 22 (1981) 40-61.

= G. I. SMIRNOvA: Skythische kannelierte Keramik im Waldsteppengebiet des nördlichen Pontus und ihre Beziehungen zum hallstattzeitlichen Donau-Karpaten-Raum. In: Xoóvos. Beiträge zur prähistorischen Archäologie zwischen Nord- und Südosteuropa. Festschrift für Bernhard Hänsel. Hrsg.: C. Becker, M. L. Dunkelmann, C. Metzner-Nebelsick, H. Peter-Röcher, M. Roeder, B. Teržan. IntArch-Stud.hon. 1. Espelkamp: Marie Leidorf Gmbh 1997, 627-636.

$=$ Г. И. СмиРновА: Заключительный сезон работ на раннескифском поселении у с. Долиняны [Final excavation season on the Early Scythian Age settlement in the village Dolinyany]. ASGE 35 (2001) 59-73.

= S. Stegmann-RAJTÁR: Eine Siedlung der Späthallstatt-Frühlaténezeit in Bratislava-Dúbravka (Slowakei). In: Die Osthallstattkultur. Akten des Internationalen Symposiums. Sopron 10-14 Mai 1994. Hrsg.: E. Jerem, A. Lippert. Archaeolingua 7. Budapest: Archaeolingua 1996, 455-471.

= S. STEGMANN-RAJTÁR: Žiarové pohrebisko východohalštatskej a vekerzugskej kultúry v Nových Zámkoch (Das Brandgräberfeld der Osthallstattkultur und der Vekerzug-Kultur in Nové Zámky. Ein Beitrag zu den hallstattzeitlichen Gräberfeldern im ostalpinen-transdanubischen Raum). S1A 57/1 (2009) 57-116.

= V. P. StePONAITIS: Technological studies of prehistoric pottery from Alabama: physical properties and vessel function. In: The Many Dimensions of Pottery: Ceramics in archaeology and anthropology. Eds: S. E. van der Leeuw, A. C. Pritchard. Amsterdam: Universiteit van Amsterdam 1984, 79-127.

= M. Szabó (dir.): L'habitat de l'époque de La Tène à Sajópetri-Hosszú dülö. Budapest: L'Harmattan 2007.

= M. SzABÓ: Les relations celto-scythes sources archéologiques. In: SzABó 2007a, 329-332.

= M. Szabó-K. TAnKó-D. Szabó: La mobilier céramique. In: Szabó 2007a, 229-252.

= D. Szabó-K. TANKó: Présentation du sistéme de gestion de céramique de Sajópetri (Hongrie). Ösrégészeti Levelek 8-9 (2006-2007) [2007] 167-176.

= G. SzABÓ-M. FeKETE: Janus szobor Pannoniából, a kora vaskori Regöly-csoport lelőhelyéről (Janus Statue aus Pannoien, vom Fundort der Regöly-Gruppe aus der Früheisenzeit). WMMÉ 33 (2011) 15-106.

= G. V. SZABÓ-Z. CZAJliK-L. Reményi: Traces of an Iron Age armed conflict. New Topographical Results from the Research into Verebce-bérc at Dédestapolcsány I. Hungarian Archaeology 
SZÖLLŐSI et al. 2009

TANKÓ 2005

TAPPERT 2015

TERŽAN 1998

TÉZER 2011

TIMÁR 2007

TIMÁR 2009

TIMÁR 2010

TITE et al. 2001

TOBERT 1984

TSALKIN 1960

TUGYA 2010a

TUGYA 2010b

TugYa in press

YAKOVENKO 1968

VADAY 2001
E-journal 2014 spring, 1-7. [online] (Avaliable on http://www.hungarianarchaeology.hu/wp-content/uploads/2014/05/eng_szabo_14TA.pdf/Accessed at $13^{\text {th }}$ May 2016).

= Sz. SZÖLlőSI-I. HAVANCSÁK-B. BAJNÓCZI-A. KREITER-Gy. SZAKMÁNY-M. Tóth: Archaeometriai vizsgálatok szerepe a kelta grafitos kerámiák régészeti interpretációjában (Role of archaeometric analysis in the archaeological interpretation of Celtic graphitic pottery). In: M $\Omega M O \Sigma$ VI. Őskoros Kutatatók VI. Összejövetelének konferenciakötete. Nyersanyagok és kereskedelem. Köszeg 2009. március 19-21. - Proceedings of the 6th Meeting for the Researchers of Prehistory. Raw Materials and Trade. Köszeg 19-21 March, 2009. Ed.: G. Ilon. Szombathely: Kulturális Örökségvédelmi Szakszolgálat; VMMIg 2009, 385-400.

= K. TANKÓ: 'Horn-handled' bowls of the Central Europe Iron Age. In: Celts on the Margin. Studies in European Cultural Interaction 7th Century BC-1st Century AD. Dedicated to Zenon Woźniak. Eds: H. Dobrzańsnka, V. Megaw, P. Poleska. Kraków: Instytut Archeologii i Etnologii Polska Akademia Nauk 2005, 153-162.

$=$ C. TAPPERT: Origins, development and distribution models of wheel-thrown pottery in Early La Tène Central Europe. In: Persistent Economic Ways of Living. Production, Distribution, and Consumption in Late Prehistory and Early History. Eds: A. Danielisová, M. Fernández-Götz. Archaeolingua 35. Budapest: Archaeolingua 2015, 167-83.

$=$ B. TERŽAN: Auswirkungen des skythisch geprägten Kulturkreises auf die hallstattzeitlichen Kulturgruppen Pannoniens und des Ostalpenraumes. In: Das Karpatenbecken und die osteuropäische Steppe. Nomadenbewegungen und Kulturaustausch in den vorchristlichen Metallzeiten (4000-500 v.Chr.). Hrsg.: B. Hänsel, J. Machnik. Prähistorische Archäologie in Südosteuropa 12. Rahden/ Westf.: Marie Leidorf Gmbh 1998, 611-560.

= Z. TÉZER: Szkíta kori településrészlet Budapest XV. kerület Rákospalota-Újmajor lelöhelyéröl (The Scythian Age site at Rákospalota-Újmajor). BudRég 44 (2011) 100-137.

= L. TIMÁR: Structure d'habitat, formes du maison. In: SZABÓ 2007a, 201-207.

= L. TIMÁR: A negatív struktúráktól a rekonstrukcióig [From negative structures to the reconstruction]. In: Régészeti dimenziók. Tanulmányok az ELTE BTK Régészettudományi Intézetének tudományos mühelyéböl [Archaeological dimensions. Studies from the scientific workshop of the Institute of Archaeological Sciences of the ELTE]. Eds: A. Anders, M. Szabó, P. Raczky. Budapest: ELTE BTK Régészettudományi Intézet; L'Harmattan 2009, 93-104.

= L. TimÁR: Les reconstitutions possibles des constructions de l'Âge du Fer, découvertes à Ráckeresztúr. In: Studia celtica classica et romana Nicolae Szabó septuagesimo dedicata. Red.: L. Borhy. Budapest: Pytheas 2010, 261-272.

= M. S. Tite-V. KiliKoglou-G. VeKinIS: Review article: strength, toughness and thermal shock resistance of ancient ceramics, and their influence on technological choice. Archaeometry 43 (2001) 301-324.

= N. TOBERT: Potters of El-Fasher: one technique practiced by two ethnic groups. In: Earthenware in Asia and Africa. Ed.: J. Picton. London: Percival David Foundation 1984, 219-237.

= В. И. ЦАлкин: Изменчивость метоподии и ее значение для изучения крупного рогатого скота древности [Metapodialia variation and its significance for the study of ancient horned cattle]. Бюллетень Московского общества испытателей природы 65 (1960) 109-126.

= B. TugYA: A kutyahús fogyasztásának archaeozoológiai bizonyítékai - The archaeozoological evidences of dog meat consumption. In: Évkönyv és Jelentés a Kulturális Örökségvédelmi Szakszolgálat 2008. évi feltárásairól - 2008 Field Service for Cultural Heritage Yearbook and Review of Archaeological Investigations. Ed.: J. Kvassay. Budapest: Kulturális Örökségvédelmi Szakszolgálat 2010, 99-106.

= B. TugYA: Állatcsontleletek Ludányhalászi-Sóderbánya lelőhelyről (Animal bone finds from Ludányhalászi-Sóderbánya, Northern Hungary). In: „Régről kell kezdenünk...” Studia archaeologica in honorem Pauli Patay. Régészeti tanulmányok Nógrád megyéből Patay Pál tiszteletére. Ed. Sz. Guba, K. Tankó. Szécsény: Gaál István Egyesület 2010, 353-365.

= B. TugYA: Szkíta kori állatcsontleletek Ecser 6.-Maglód 1. lelőhelyről (Scythian Age animal remains from Ecser 6.-Maglód 1. site). In: Emlékek az idő kútjából. Megelőző régészeti feltárások az M0-s autópálya délkeleti, valamint a 4. számú főút Vecsést és Üllőt elkerülő szakaszain, 2001-2006. (Memories from the Well of Time. Preventive archaeological excavations along the SE sector of the M0 Motorway and the Highway no 4 section around Vecsés and Üllö, 2001-2006). Ed.: R. Patay. Szentendre: Ferenczy Múzeumi Centrum.

= Е. В. ЯАковенко: Пастирське городище скижфського часу (За материалами розкопок 1955 p.) [Scythian Age fortified settlement Pastirske (Finds from the excavations in 1955)]. ArhKiev 21 (1968) 175-186.

= A. VADAY: Előzetes jelentés a Salgótarján, Ipari park II. régészeti feltárásáról [Preliminary report of the archaeological excavation of Salgótarján, Industrial Park II]. NMMÉ 25 (2001) 209-215. 
VADAY 2003

VASIĆ 1987

VASILIEV 1980

VERES 2003

VERES 2008

VÉKONY 1986

WOLLÁK 1979

Woods 1986

ZIRRA 1976
= A. VADAY: Salgótarján, Ipari-park II. lelöhely - Salgótarján, Industrial Park II site. In: RégKut 2000. Ed.: J. Kisfaludi. Budapest: Kulturális Örökségvédelmi Hivatal; Magyar Nemzeti Múzeum 2003, 31-38.

= R. VAsIĆ: Bosutska grupa [The Bosut group]. In: Praistorija jugoslovenskih zemalja. 5.: Željezno doba. Red.: S. Gabrovec. Sarajevo: Akademija nauka i umjetnosti Bosne i Hercegovine; Centar za balkanološka ispitivanja 1987, 536-554.

= V. VAsILIEv: Sciţii agatîrşi pe teritoriul României (Die Skythen-Agathyrsen auf dem Gebiete Rumäniens). Cluj-Napoca: Editura Dacia 1980.

= J. VERES: Szkíta kori település Polgár határában (Scythian settlement on the outskirts of Polgár). Ösrégészeti Levelek 5 (2003) 83-93.

= J. VERES: Régészeti adatok egy Hernád-völgyi szkíta kori településobjektum elemzése kapcsán (Finds from a scythian settlement in the Hernád valley). HOMÉ 47 (2008) 53-87.

= G. VÉKONY: Zu einigen Fragen der Hallstattzeit des östlichen Transdanubiens. In: Hallstatt Kolloquium Veszprém 1984. Hrsg. : E. Jerem. MittArchInst Bh 3. Budapest 1986, 259-265, 477-482.

= K. WolláK: Hallstattkori leletek a Pilismarót-szobi révi telepfeltárásból (Hallstattzeitliche Funde aus der Erschliessung der Siedlung von Pilismarót-Szobi rév). DRK 1. Budapest: Magyar Nemzeti Múzeum 1979, 49-76.

= A. Woods: Form, fabric and function: some observations on the cooking pot in Antiquity. In: Technology and Style. Ed. W. D. Kingery. Ceramics and civilization 2. Westerville, Ohio: The American Ceramic Society 1986, 157-172.

= V. ZIRRA: Über die Henkelgefässe im ostkeltischen Raum (Transsilvanien). In: Festschrift für Richard Pittioni zum siebzigsten Geburtstag. Hrsg.: H. Mitscha-Märheim, H. Friesinger, H. Kerchler. ArchA Bh 13. Wien: Deuticke 1976, 777-818. 